\title{
12. PLANKTONIC FORAMINIFERAL BIOSTRATIGRAPHY AND PALEOENVIRONMENTAL INTERPRETATION OF PALEOGENE FAUNAS FROM THE SUBANTARCTIC TRANSECT, LEG 1141
}

\author{
Marisa Nocchi, ${ }^{2}$ Emanuela Amici, ${ }^{2}$ and Isabella Premoli Silva ${ }^{3}$
}

\begin{abstract}
Paleogene planktonic foraminifers recovered during ODP Leg 114 in the subantarctic region exhibit a cosmopolitan character at the opening of the Paleocene, and then they evolve similarly to faunas from lower latitudes. They begin to differentiate from lower latitude faunas by the early late Paleocene when large morozovellids disappear from the region and cool deep-water-dwelling Globorotaloides appear much earlier than at lower latitudes. By early Eocene time large morozovellids immigrate into the subantarctic area during the warmest episode of the entire Eocene. From that time up to the end of the middle Eocene planktonic foraminiferal faunas exhibit a temperate character, as indicated by the abundance of common acarininids. At the same time dissolution at depth causes depauperated planktonic faunas at the deeper sites. A new warming episode during the late Eocene is marked by the immigration of Globigerinatheka luterbacheri into the subantarctic region. The cooling trend during the late Eocene causes a progressive decrease in species richness, which only sporadically is less than 10 species. The early Oligocene is also characterized by relatively rich planktonic faunas, but after that time the western subantarctic region is occasionally invaded by few planktonic foraminiferal species. These immigrations coincide with the warmer episodes on the climatic curve, such as Zones P21a and P22-"N4."

Beginning in late early Eocene and through the Oligocene eastern subantarctic planktonic foraminiferal faunas exhibit a much warmer character than those from the western side and are more similar to warm temperate faunas. Therefore, the eastern faunas provide a more refined biostratigraphy. Oligocene time is characterized by a trend toward a warmer climate; however, this trend was reversed in the early Miocene.

A dissolution event, possibly coeval with an erosional event, occurs within Zone P21b across the subantarctic region.
\end{abstract}

\section{INTRODUCTION}

The seven sites (698 through 704) drilled during Ocean Drilling Program (ODP) Leg 114 in the subantarctic South Atlantic Ocean are located in the wide passageway linking the South Atlantic to the Weddell Sea Basin (Fig. 1A). The water depths of the various sites range from 2138 to $4636.7 \mathrm{~m}$ (Table 1). An almost continuous Upper Cretaceous to Holocene sedimentary sequence is represented by carbonate and siliceous biofacies along a west-east longitudinal transect across the Mid-Atlantic Ridge (Fig. 1B). Sites 698 through 702 were drilled on the western side and Sites 703 and 704 on the eastern side of the Mid-Atlantic Ridge. They are located on basement rises and in basins underlain by oceanic crust extending between the eastern end of the Maurice Ewing Bank on the west to the western termination of the Agulhas Plateau on the east, which represent the tips of South American and South African continental crust, respectively.

Rifting of the South Atlantic probably was initiated during the Late Jurassic (approximately $180 \mathrm{Ma}$ ) while seafloor spreading began in the Early Cretaceous. The rate of formation of South Atlantic oceanic crust increased from 75 until 35 $\mathrm{Ma}$, in the early Oligocene (Sclater and McKenzie, 1973), when the investigated area reached its present latitudinal position. At present, the subantarctic southern Atlantic is a tectonically stable oceanic area south of the Falkland-Agulhas

${ }^{1}$ Ciesielski, P. F., Kristoffersen, Y., et al., 1991. Proc. ODP, Sci. Results, 114: College Station, TX (Ocean Drilling Program).

${ }^{2}$ Dipartimento di Scienze della Terra, Università di Perugia, Piazza dell'Università, 06100 Perugia, Italy.

${ }^{3}$ Dipartimento di Scienze della Terra, Università di Milano, Via Mangiagalli, 34, 20133 Milano, Italy.
Fracture Zone and north of the triple junction of the South American, South African, and Antarctic plates.

Based on reconstruction of the spreading centers (LaBrecque, 1986; LaBrecque and Hayes, 1979), during the Paleogene some major tectonic events changed the physiography of the Falkland-Agulhas passageway:

1. In the early Paleocene Zone P1 the presence of a barrier at depth partially prevented deep-water circulation between the South Atlantic and the Weddell Sea basins. Such a barrier, at water depths of possibly less than $2000 \mathrm{~m}$, was created during the Late Cretaceous by the westward shift of the ridge axis in the Agulhas basin.

2. During the late Paleocene a new spreading center formed between the Islas Orcadas Rise and Meteor Rise aseismic ridges, two conjugate features now on the western and eastern flanks of the Mid-Atlantic Ridge, respectively.

3. In middle Eocene Zones P11-12 the beginning of the formation of a large basin, about $1500 \mathrm{~km}$ wide, between the two aforementioned aseismic ridges was caused by continuous spreading and thermal tectonic subsidence and allowed deeper currents to flow northward.

Moreover, during the Paleogene several plate tectonic events had a strong influence on circulation on a global scale. Among these are the increasing separation of Australia from Antarctica (Weissel and Hayes, 1972) during the Eocene, which created a stronger circulation system on the Pacific side of Antarctica and the clearance of shallow-water barriers between the southern end of the South Tasman Rise and Antarctica in the early Oligocene and between the Campbell Plateau and Antarctica in the late Oligocene (Kennett, 1977, 1978). The deep clearance of the Drake Passage along the Shackleton Fracture Zone was completed by 23 Ma (early Miocene) (Barker and Burrell, 1977). The latter event re- 

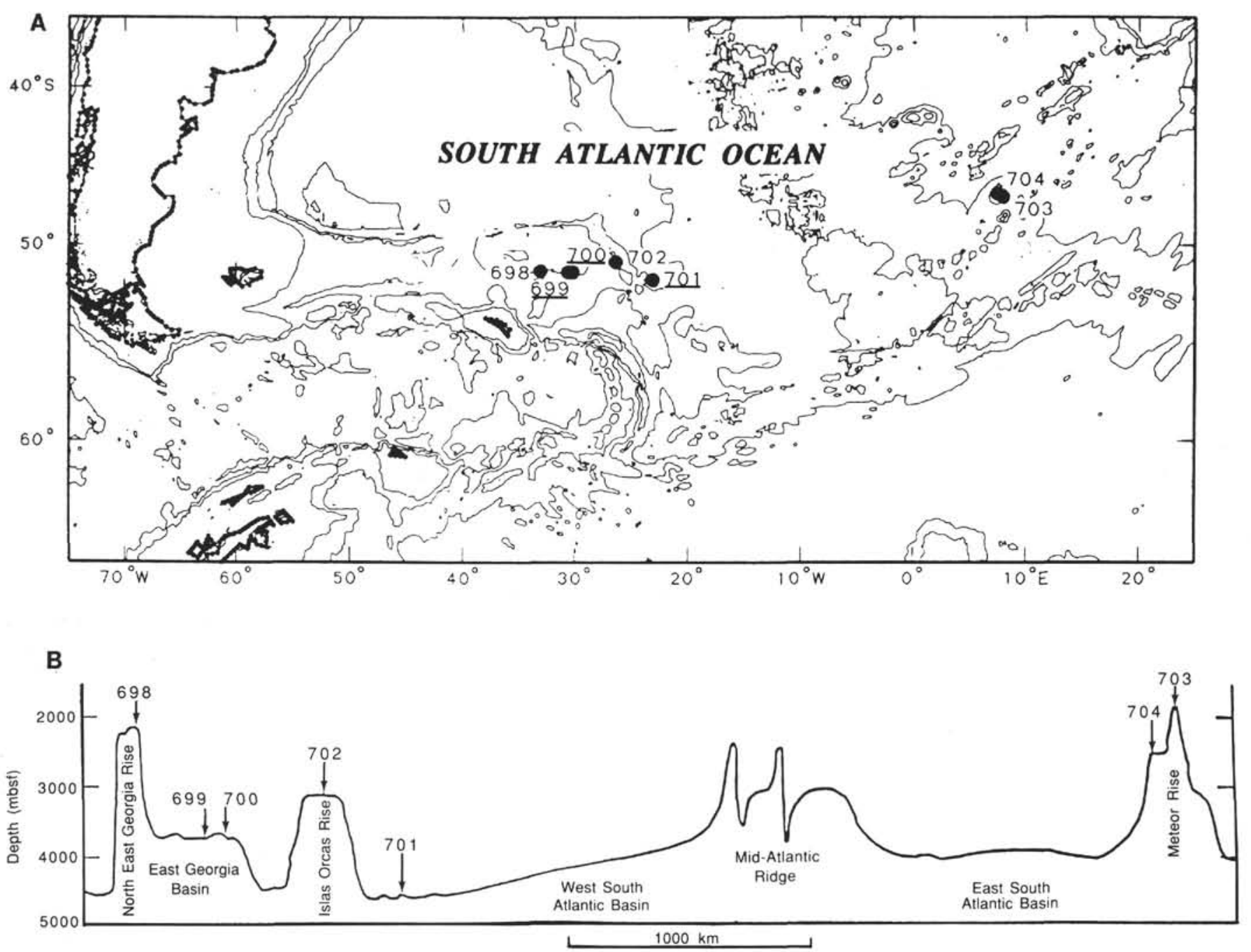

Figure 1. A. Location of Leg 114 sites in the subantarctic South Atlantic. B. West-east longitudinal transect across the Mid-Atlantic Ridge.

Table 1. Location and water depth of Leg 114 sites.

\begin{tabular}{|c|c|c|c|c|}
\hline Hole & Latitude & Longitude & $\begin{array}{l}\text { Water } \\
\text { depth } \\
(\mathrm{m})\end{array}$ & $\begin{array}{l}\text { Total } \\
\text { penetration } \\
\text { (mbsf) }\end{array}$ \\
\hline 698A & $51^{\circ} 27.51^{\prime} \mathrm{S}$ & $33^{\circ} 0596^{\prime} \mathrm{W}$ & 2138.0 & 237.0 \\
\hline $699 \mathrm{~A}$ & $51032.537 \mathrm{~S}$ & $30^{\circ} 40.619^{\prime} \mathrm{W}$ & 3705.5 & 518.1 \\
\hline $700 \mathrm{~A}$ & $51^{\circ} 31.992 ' \mathrm{~S}$ & $30^{\circ} 6.697 \mathrm{~W}$ & 3601.0 & 9.6 \\
\hline $700 \mathrm{~B}$ & $51^{\circ} 31.977 \mathrm{~S}$ & $30^{\circ} 16.688^{\prime} \mathrm{W}$ & 3601.0 & 489.0 \\
\hline $701 \mathrm{~A}$ & $51^{\circ} 59.076$ 'S & $23^{\circ} 12.736^{\prime} \mathrm{W}$ & 4636.7 & 74.8 \\
\hline $701 \mathrm{~B}$ & $51^{\circ} 59.077 \mathrm{~S}$ & $23^{\circ} 12.735^{\prime} \mathrm{W}$ & 4636.7 & 203.0 \\
\hline $701 \mathrm{C}$ & $51^{\circ} 59.085$ 's & $23^{\circ} 12.700^{\prime} \mathrm{W}$ & 4636.7 & 481.4 \\
\hline $702 \mathrm{~A}$ & $50^{\circ} 56.786$ 's & $26^{\circ} 22.127^{\circ} \mathrm{W}$ & 3083.4 & 33.1 \\
\hline $702 \mathrm{~B}$ & $50^{\circ} 56.786$ 'S & $26^{\circ} 22.117 \mathrm{~W}$ & 3083.7 & 294.3 \\
\hline $703 \mathrm{~A}$ & $47^{\circ} 03.042^{\prime} \mathrm{S}$ & $07^{\circ} 53.679^{\prime} \mathrm{E}$ & 1796.1 & 377.4 \\
\hline $704 \mathrm{~A}$ & $46^{\circ} 52.757 \cdot \mathrm{S}$ & $07^{\circ} 25.250^{\circ} \mathrm{E}$ & 2532.3 & 282.7 \\
\hline $704 \mathrm{~B}$ & $46^{\circ} 52.758^{\prime} \mathrm{S}$ & $07^{\circ} 25.231^{\prime} \mathrm{E}$ & 2532.3 & 671.7 \\
\hline
\end{tabular}

moved the last physiographic barrier to a full circum-Antarctic circulation system.

The drill sites are located at present-day latitudes of $51^{\circ} \mathrm{S}$ to $46^{\circ} \mathrm{S}$ (Table 1). Sites 698 through 702 , to the west of the Mid-Atlantic Ridge, are within the Polar Front Zone and belong to the Subantarctic bioprovince (Bé and Tolderlund, 1971), and thus to the high latitudes, which in the Southern
Hemisphere include water masses south of $50^{\circ} \mathrm{S}$ (Kennett, 1978). The Antarctic Convergence today sharply separates a southern bioprovince-characterized by widespread erosion at depth related to cold, aggressive bottom waters, the accumulation of ice-rafted material, and biogenic silica production-from a northern province, where calcareous sediments predominate (Kennett, 1977).

The abundance of Paleocene to Eocene age calcareous sediments recovered at the drill sites indicates that environmental conditions in the area investigated by Leg 114 were much warmer than at present and similar to those presently recorded north of the Antarctic Convergence. Through the remainder of the Paleogene, paleoclimatic and paleoceanographic conditions reflect a progressively cooler climate. Oceanwide cooling event(s) resulted in biotic changes that, in turn, produced an accumulation of different types of sediments (from calcareous to siliceous) (Keigwin and Corliss, 1986; Krasheninnikov and Basov, 1986; Boersma et al., 1987).

The aims of the Leg 114 drilling program were (1) to link regional tectonic events to the opening of the gateway that allowed the antarctic cold waters to flow northward into the Argentine Basin through the Falkland-Agulhas Fracture Zone and (2) to reconstruct the evolution of the climatic conditions that resulted in the disappearance of carbonate-rich biofacies indicative of warmer conditions and their replacement by silica-rich biofacies. 
Lower Paleocene to upper Eocene sediments yielded rich planktonic foraminiferal assemblages, only slightly affected by dissolution, at Site 702, which is located on a basement high and has a low subsidence rate. Calcareous biofacies were truncated by an erosional event during the late Eocene to the west of the Mid-Atlantic Ridge, while to the east they persisted into the Oligocene and early Miocene. Thus, if both sides of the Mid-Atlantic Ridge are considered, a composite Paleogene record is completely represented by calcareous biofacies and planktonic foraminifers that are present throughout. In general, the planktonic foraminiferal assemblages are enriched in thick-walled, high-latitude index species (high dominance), whereas thermophilic species have shorter ranges and/or disappear earlier than at lower latitude (Boersma and Premoli Silva, 1983; Boersma et al., 1987; Premoli Silva and Boersma, 1988). Planktonic foraminiferal distributions, nevertheless, do allow reliable correlation with the lower latitude standard zonation.

Precise age assignment of the basement or plate tectonic events, however, needs the combined potential biostratigraphic resolution of both calcareous planktonic groups, calcareous nannofossils and planktonic foraminifers.

\section{METHODS}

The present study is based on the examination of corecatcher samples and one sample taken per section. Sample volume was about $10 \mathrm{~cm}^{3}$. All samples were soaked in a solution of $5 \%$ hydrogen peroxide and boiled for $10 \mathrm{~min}$ when necessary, and then they were washed on a $40-\mu \mathrm{m}$ sieve and dried under a heat lamp. The washed residues were sieved and split into two size fractions: $>150$ and $150-40 \mu \mathrm{m}$.

One of the major problems in studying planktonic foraminifers from a high-latitude ocean environment is selective solution affecting planktonic foraminifers, which removes numerous, typically age-diagnostic taxa (e.g., Toumarkine, 1978; Premoli Silva and Boersma, 1988). Thus, we have tried to collect as much information as possible in order to reconstruct the original biocoenosis.

In order to obtain a more complete record from such high-latitude material, in addition to species identification, species abundance was quantitatively estimated on the size fraction $>150 \mu \mathrm{m}$. We evenly spread an aliquot of each $>150-\mu \mathrm{m}$ residue twice over a picking tray with a standard 60 -square grid. Abundances were estimated relative to the total planktonic foraminiferal assemblage by counting specimens on randomly chosen grid squares. Five categories are distinguished and plotted in the range charts or used for reconstructing the abundance curves:

$\mathrm{S}=$ one to three specimens,

$\mathrm{R}=$ rare (less than $3 \%$ ),

$\mathrm{F}=$ few $(3 \%-15 \%)$,

$\mathrm{C}=$ common $(15 \%-30 \%)$

$\mathrm{A}=$ abundant (more than $30 \%$ and dominant).

Only semiquantitative analyses were performed on the $<150-\mu \mathrm{m}$ size fraction of each sample. Estimates concern the most significant groups of small planktonic foraminifers, the chiloguembelinids, planorotalitids, pseudohastigerinids, and tenuitellids, and some diagnostic species, generally of larger size, but confined to the $<150-\mu \mathrm{m}$ size fraction for ecologic reasons. The total abundance of planktonic foraminifers relative to other biogenic constituents was similarly estimated.

The occurrence and abundance of selected species and groups have been plotted for Sites $698,699,700,702$, and 703 against the biostratigraphic framework and time scales of Berggren et al. (1985) in Tables 2 through 6.

The major biostratigraphic events were plotted against sub-bottom depth, recovery, and the standard zonal scheme to construct synthetic lithologic logs for each site (Fig. 2). Weight percentages of the washed residue vs. original sample weight; species diversity (Jenkins, 1968) including some informal groups (see Appendix); the planktonic foraminifer/planktonic foraminifer + siliceous organism ratio; and subbotinid/ subbotinid + acarininid (S/SA) ratio-the latter two on washed residues $>150 \mu \mathrm{m}$-were also plotted (Figs. 3 through 13). These values were estimated in the same quantitative way as described previously. Moreover, the estimation of the S/SA ratio in the size fraction $<150 \mu \mathrm{m}$ at Site 702 yielded the best preserved assemblages and provided a direct calibration between magnetostratigraphy and biostratigraphy.

Special attention was also devoted to the state of preservation of planktonic foraminifers. Although it was impossible to apply the solution ranking facies identified by Berger and von Rad (1972) because of climatic exclusion of several solution-susceptible taxa, three solution "stages" were recognized based on etching and fragmentation of foraminiferal tests (see Table 2).

Reworking was a serious problem only at the two eastern sites. Among the indigenous forms we considered reworked are those taxa that, after their local extinction preceded by a gradual decrease in abundance, reappeared at much younger levels. This criterion could not be applied to immigrant forms, such as subtropical warmer species, whose occurrence was already irregular and random. In this case we could rely only on their different stratigraphic range, if any.

Downhole contamination was not indicated in the range charts, but it was a serious problem at some portions of Sites 703 and 704 , where soupy material was recovered and the age differences among planktonic assemblages were minimal.

\section{SITE DESCRIPTION}

Preliminary biostratigraphic data from each subantarctic site are included in the Leg 114 Initial Reports volume (Ciesielski, Kristoffersen, et al., 1988). This chapter is concerned primarily with the major characteristics of the planktonic foraminiferal assemblages, their distribution, and the intensity of dissolution at each site.

\section{Site 698}

Site 698 is located near the eastern edge of the shallowest portion of the Northeast Georgia Rise, an oceanic plateau of mid-Cretaceous to Paleogene age. This site is approximately 60 to $100 \mathrm{~km}$ south of the mean present-day site of the Antarctic Convergence Zone. The primary objectives at Site 698 were mainly tectonic and paleogeographic in nature, with the aim of evaluating the influence of the Northeast Georgia Rise as a Late Cretaceous-Paleogene obstruction to deepwater interchange between the Weddell and South Atlantic basins.

An apparently complete, 190-m-thick sequence of pelagic, carbonate-rich sediments of Campanian to late early Eocene (Zone P9) age was recovered above basement at Site 698. The Paleogene portion spans about three-fifths of the entire sedimentary sequence and is truncated by a major hiatus spanning the remaining portion of the Eocene up to the PliocenePleistocene.

The Paleogene sequence consists of nannofossil chalk at the Cretaceous/Paleocene boundary grading upward to a nannofossil ooze. The calcium carbonate content is as high as $90 \%$, indicating that dilution by terrigenous and/or biogenic silica is minimal throughout the Paleocene and early Eocene age interval.

Planktonic foraminifers are common to abundant and dominate other pelagic organisms (Table 2 and Figs. 3 and 4). Radiolarians are generally rare to few except in the lower part 
Diatom ooze (SB1)

Fैํํㄱ Diatom radiolarian

f.ffy or siliceous ooze (SB3)
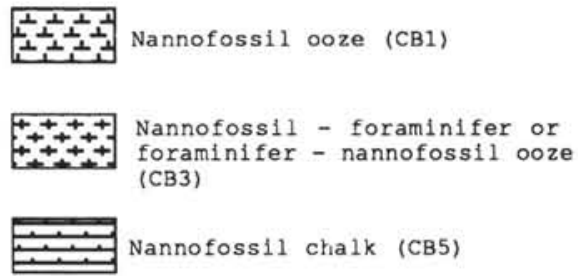
Nannofossil - foraminifer or
foraminifer - nannofossil ooze
(CB7)

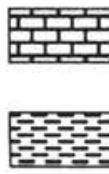

Limestone (CB9)

Clay/claystone (T1)

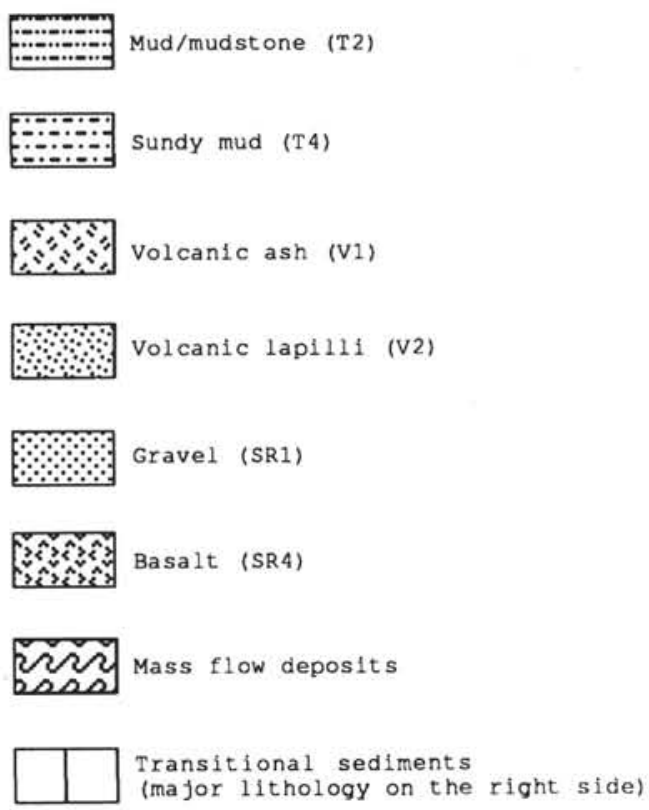

(major lithology on the right side)

Figure 2. Symbols used in the figures of this paper.

of Zone P4 and in Zone P9, where they are more abundant (Fig. 4). Chert nodules are scattered throughout, suggesting that siliceous organisms were possibly more common than apparent in the washed residues. Planktonic foraminiferal tests are extensively recrystallized in the lower Paleocene. From the upper Paleocene up to the uppermost lower Eocene, planktonic foraminifers are moderately to well preserved, with sporadic occurrences of slight corrosion by dissolution. The depositional environment is interpreted to have been always above the foraminiferal lysocline. This interpretation is in agreement with the water depth estimate based on benthic foraminifers, from $750 \mathrm{~m}$ in the late Paleocene to 1000 $\mathrm{m}$ in the latest early Eocene (Katz and Miller, this volume). There is no evidence of reworking.

Because of poor recovery, especially in the lower portion of the Paleocene, some biozones, such as Zones Palpha, P2, P3a, P3b, and the transition between Zones P4 and P5, could not be documented. As indicated by calcareous nannofossils, Zone Palpha may be missing because of a hiatus (Ciesielski, Kristoffersen, et al., 1988). Although the occurrence of other short hiatuses cannot be ruled out, the succession of foraminiferal events appears to be regularly spaced.

The Paleocene/Eocene boundary, placed according to calcareous nannofossil data and marked by the first occurrence (FO) of Planorotalites pseudoscitulus, could be documented only at Site 698 . The Eocene sequence ends within the Morozovella crater Zone (mainly Zone P9), of which the upper part is truncated by the aforementioned major hiatus.

Planktonic foraminiferal species diversity (= species richness) increases from the Paleocene to the lower Eocene (Fig. 4) with a mean of 25 species and a maximum diversity of 43 species. The S/SA ratio varies from high percentages of round-chambered acarininids in the uppermost Paleocene and lowermost Eocene to higher percentages of subquadrate acarininids and subangular biconvex morozovellids in Zone P8.

\section{Site $699^{4}$}

Site 699 , drilled on the northeastern slope of the Northeast Georgia Rise, was selected to (1) obtain a continuously cored sedimentary sequence of Late Cretaceous to Neogene age, (2) record the history of deep-water communication between the Weddell and Georgia basins and the South Atlantic Basin, and (3) document the development of the Antarctic Circumpolar Current. The recovered section ranges in age from late $\mathrm{Pa}$ leocene (Zone P4) to Pleistocene. Paleogene sediments are 415 $\mathrm{m}$ thick within the total $518 \mathrm{~m}$ drilled.

The lower part of the sequence, about $180 \mathrm{~m}$ thick, consists of nannofossil chalk, ranging in age from late Paleocene through late Eocene, grading upward into a siliceous nannofossil ooze with an increase of the biosiliceous components. The carbonate fraction ranges from $70 \%$ in the lower to middle Eocene, shows strong fluctuations (between $75 \%$ and $0 \%$ ) from the upper Eocene to Oligocene, and disappears almost completely at $85 \mathrm{~m}$ below seafloor (mbsf), just above the Oligocene/Miocene boundary. Paleogene sediments are mainly pelagic, mostly biogenic, except the basal $21 \mathrm{~m}$ of upper Paleocene sediments, which displays an high clay content. The clay source is supposed to be located in the southern Andean Cordillera with clay dispersed as a thick nepheloid

\footnotetext{
4 After this paper was accepted for publication, new paleomagnetic data were produced, especially for Site 699 . The new data were unavailable for modifying Figure 5 and Table 3, which accordingly lack precise locations of the magnetic chrons identified in the sequences. This accounts for the discrepancies among the text and figures for the early to middle Eocene boundary (19 October 1990).
} 
suspension (Ciesielski, Kristoffersen, et al., 1988). In the Zone P4 clayey sediments radiolarians are more abundant than planktonic foraminifers (Figs. 5 and 6). Above this terrigenous interval, planktonic foraminifers continuously dominate the assemblages in the lower Eocene up to the lower middle Eocene (Zones P10-11). From the upper middle Eocene to upper Eocene planktonic foraminifers decrease in abundance and marked fluctuations in the planktonic foraminifer/siliceous organism ratio are recorded. In the uppermost Eocene planktonic foraminifers become very rare or absent, whereas siliceous organisms increase in abundance. Calcium carbonate is still present, although low in percentage, but it is related to the presence of calcareous nannofossils. Within the Oligocene planktonic foraminifers are very rare and occur sporadically only in the small fraction. The gradual decrease of calcareous biofacies from the lower middle Eocene through the Oligocene is visible in the calcium carbonate curve as well (Ciesielski, Kristoffersen, et al., 1988).

The degree of dissolution of planktonic foraminifers increases upward in the sequence as their abundance decreases. In the upper Paleocene the poor preservation is interpreted as due to diagenetic effects rather than dissolution because the foraminiferal tests do not show any etched chambers. In the lower Eocene preservation is moderate with signs of slight dissolution, whereas in the middle Eocene it ranges from moderate to poor with increasing dissolution starting in Core 114-699A-43X. In the upper Eocene only solution-resistant species such as Catapsydrax, Globorotaloides, Globigerinatheka index, and the Subbotina angiporoides group occur. Within the Oligocene the rare and sporadic planktonic foraminifers are only the solution-resistant species with very thick walls. Only by the upper Oligocene have rare species, considered not solution resistant, such as Cassigerinella chipolensis, been found.

The depositional environment at Site 699 was clearly above the foraminiferal lysocline in the early Eocene and deepened gradually toward a depth oscillating between the foraminiferal lysocline and the carbonate compensation depth (CCD) during the Oligocene. According to benthic foraminifers, the seafloor sank from $2700 \mathrm{~m}$ in the early Eocene/middle Eocene to a depth of more than $3000 \mathrm{~m}$ in the early Oligocene (Katz and Miller, this volume). This is in agreement with an estimated depth of the CCD in the South Atlantic of about $4000 \mathrm{~m}$ during the Oligocene, as suggested by van Andel (1975).

No major hiatuses are found in the Paleogene sequence. Poor recovery prevents us from either proving or disproving the presence of a widespread unconformity in the South Atlantic Ocean at the Paleocene/Eocene boundary. A hiatus possibly occurs at the middle to late Eocene boundary. This hypothesis is based on the fact that sediments of late middle Eocene age are too thin (only $20 \mathrm{~m}$ thick) in comparison with the thickness of coeval sediments recorded at Sites 700 and 702 (approximately $70 \mathrm{~m}$ thick). This is corroborated by the closeness of the FO of Paragloborotalia opima nana and the last occurrence (LO) of Acarinina primitiva at Site 699, as well as by calcareous nannofossils (Crux, this volume).

Reworked foraminifers are apparently absent except for rare Cretaceous Whiteinella $\mathrm{sp}$. recorded in the lower middle Eocene (Table 3, in back pocket).

Within the lower Eocene and in the lower middle Eocene species diversity is high (more than 20 species), decreasing to less than 10 species in the Oligocene, when they occur. According to Jenkins $(1968,1973)$ species diversity less than 12 indicates either a cold-temperate to subpolar climate or secondary diversity caused by dissolution (Orr and Jenkins, 1977). Comparison of species diversity curves from Sites 699 and 702, located at the same latitude and during the same time interval, indicates that low diversity at Site 699 is secondary and caused by selective, destructive solution. Moreover, in the middle Eocene several species belonging to the biconvex morozovellids, small acarininids, and the pseudohastigerinids disappear earlier than at Sites 700 and 702 . These disappearances are also interpreted as local events related to dissolution.

The S/SA ratio ranges about $50 \%$ on average in the lower Eocene and decreases suddenly within Zone P11 where species diversity is very low (Fig. 6) due to the marked dominance of $A$. primitiva, a very solution-resistant species. The S/SA ratio then increases rapidly up to $100 \%$ after the extinction of $A$. primitiva.

At this site a 20 -m-thick Morozovella crater Zone (corresponding to mainly Zone P9) was identified. The LO of $M$. crater is within Chron 21R (Hailwood and Clement, this volume).

In conclusion, Site 699 shows an increasing dissolution of calcareous organisms, and thus, it is not adequate to depict the global cooling event, recognized in the Oligocene, by means of planktonic foraminifers.

\section{Site 700}

Site 700 was drilled in the western region of the East Georgia Basin on the northeastern slope of the Northeast Georgia Rise. The objectives for Site 700 were complementary to those reported for Site 699 .

The $465-\mathrm{m}$-thick sequence consists of pelagic carbonate sediments rich in planktonic foraminifers, ranging in age from late Turonian to late middle Eocene, overlain by $25 \mathrm{~m}$ of Pliocene-Pleistocene diatom ooze. The Paleogene section occupies about two-thirds of the entire sequence, and the sediments have been affected by progressive lithification with depth, from nannofossil ooze to nannofossil chalk, micritic nannofossil chalk, and indurated chalk. Through the entire Paleogene sequence the carbonate content is almost constant (approximately $80 \%$ ) except for a single level in upper $\mathrm{Pa}$ leocene Zone P4 where carbonate content drops to $1 \%$ and another interval of late middle Eocene age in which carbonate content is only $60 \%$ on average. The Zone P4 carbonate low corresponds to a siliceous-bearing claystone horizon. Chert nodules occur only at the top of Zone P4.

Most of the Paleocene sediments yield abundant radiolarians, whereas planktonic foraminifers are abundant only in the lower to middle part of Zone P1b (Table 4, back pocket, and Figs. 7 and 8). Radiolarians constitute the entire planktonic microfauna in the Zone P4 claystone layer. Planktonic foraminifers again become very abundant and dominant throughout the Eocene sequence whereas radiolarians are rare. Only at the top of the sequence does the radiolarian content increase again.

Within the Paleocene, preservation of planktonic foraminifers ranges from poor to moderate as a result of strong recrystallization without any etching. The occurrence of abundant siliceous organisms does not seem to have affected the preservation of the planktonic foraminifers.

Above the Paleocene, planktonic foraminiferal preservation is moderate with signs of only slight dissolution. By the upper middle Eocene evidence of dissolution suddenly becomes very strong: most of the foraminiferal tests are fragmented with few whole specimens preserved in the size fraction $>150 \mu \mathrm{m}$; in contrast, benthic foraminifers increase in abundance (= near lysocline fauna; Boersma, 1977).

According to the benthic assemblages, the water depth at Site 700 is estimated to have been nearly $2200 \mathrm{~m}$ in the early Paleocene, then deepening down to $2500 \mathrm{~m}$ by latest early Eocene (Katz and Miller, this volume). Thus, it was above the 
Table 2. Stratigraphic ranges and relative abundances of Paleogene planktonic foraminifers and other selected organisms in Hole 698A.

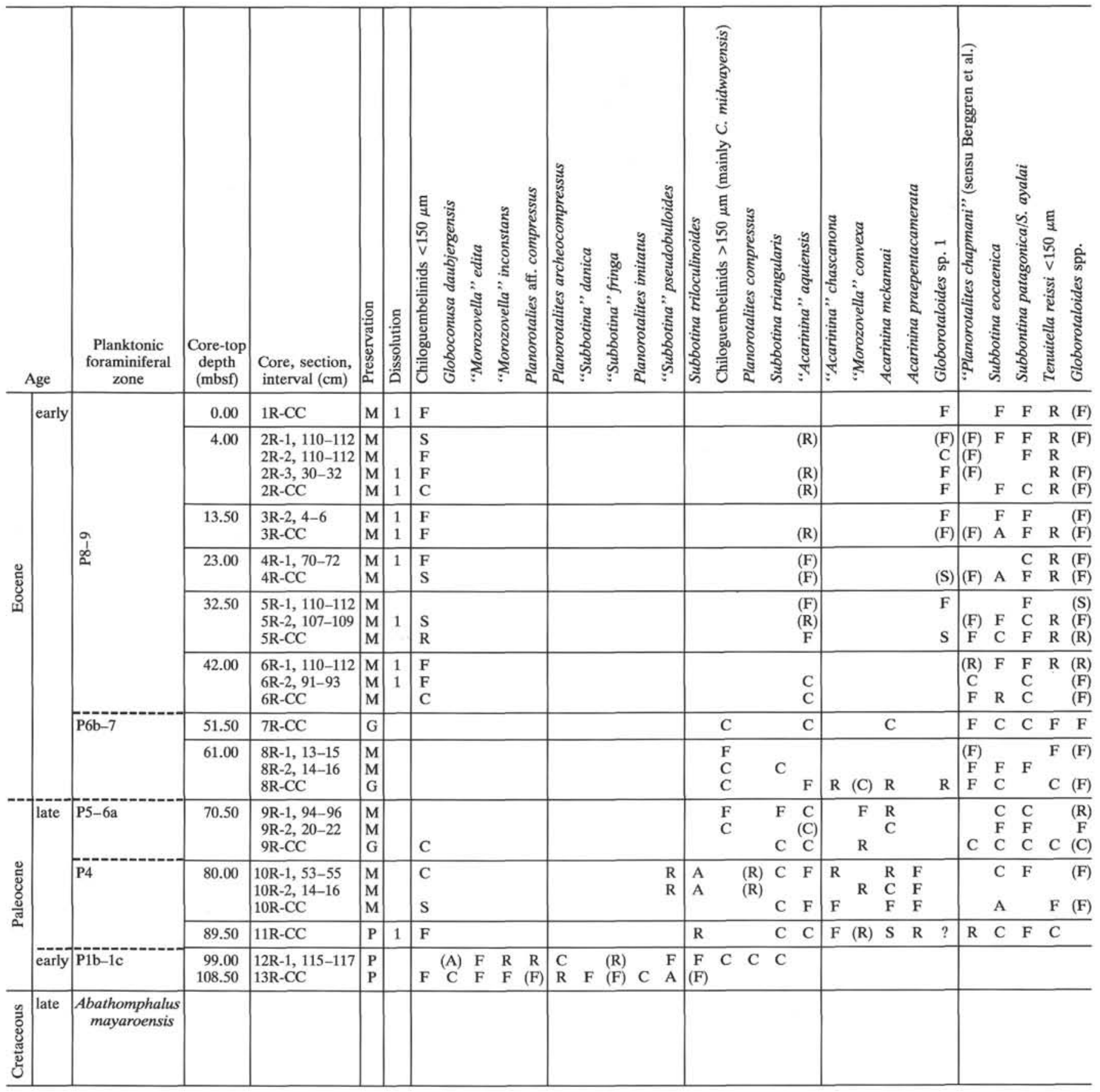

foraminiferal lysocline earlier than the late middle Eocene, when the increasing rate of subsidence dropped the seafloor at Site 700 to a depth close to that of the foraminiferal lysocline.

There is no apparent evidence of reworking among the planktonic foraminifers.

Both the regular succession of events and sediment thickness indicate that no major hiatuses affected the Paleogene sequence at this site until the latest middle Eocene. At this level the Paleogene sequence is truncated by a major hiatus spanning the remaining portion of the upper Eocene up to the Pliocene-Pleistocene. Moreover, poor recovery (20-m sampling gap above Zone P4) once more prevents either proving or disproving the presence of an unconformity at the $\mathrm{Pa}$ leocene/Eocene boundary.

Species diversity ranges from 12 in the Paleocene, to $25-42$ from lower Eocene Zone P6b up to the lower middle Eocene, then fluctuates between 11 and 27 in middle Eocene Zones P11-12, and finally decreases to value less than 10 in the upper middle Eocene. Diversity and percentage figures suggest that planktonic foraminifers were the dominant organisms in the early and early middle Eocene (Fig. 8).

The acarininids occur in abundance from upper Paleocene Zone P3 up to middle Eocene Zone P11, with some fluctuations from level to level. They become dominant in middle 
Table 2 (continued).

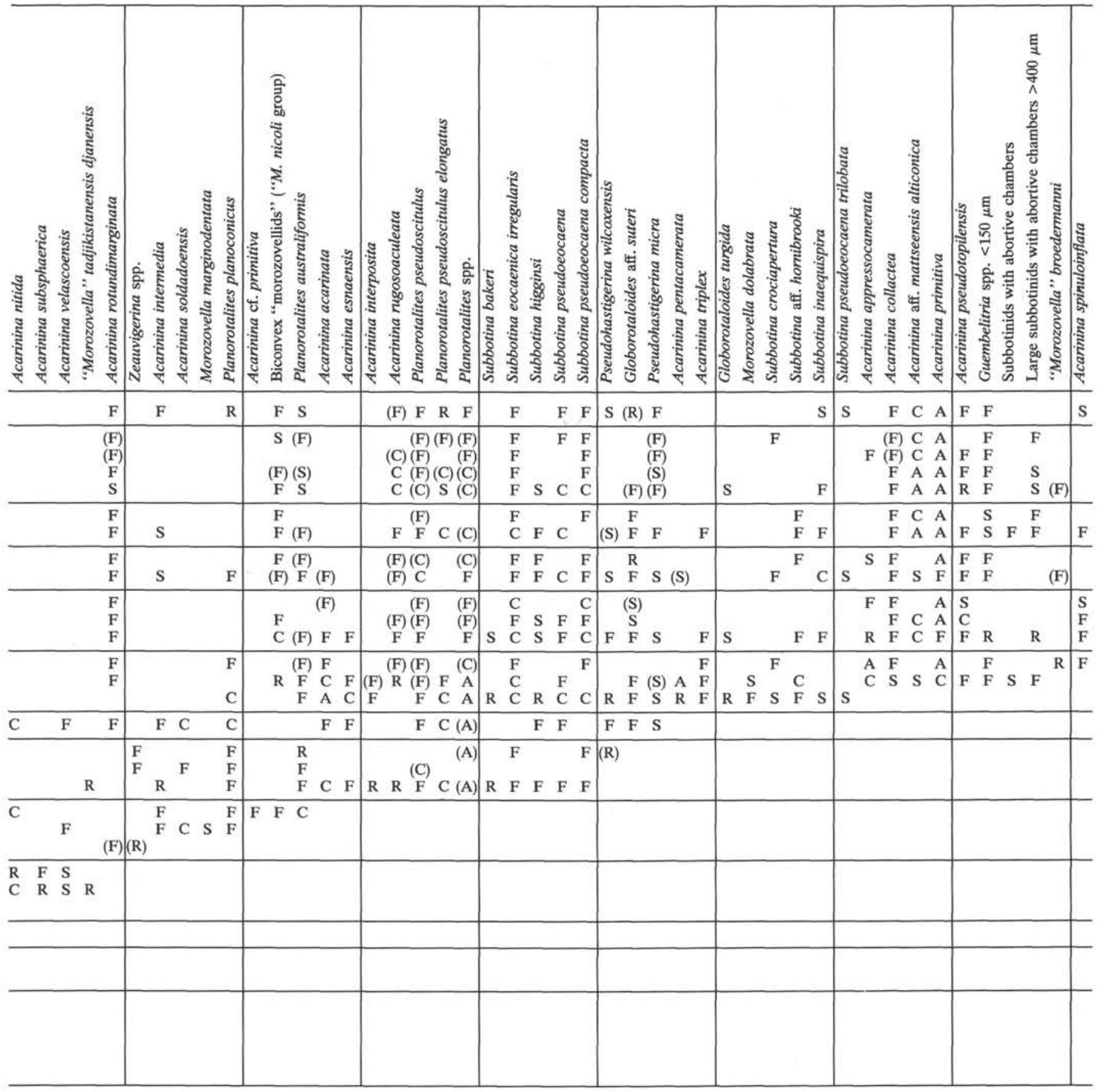

Eocene Zones P11-12, but their abundance depends upon dissolution that does not affect the very solution-resistant Acarinina primitiva. A Morozovella crater Zone at least $10 \mathrm{~m}$ thick is also recorded at this site. Biofacies evolution at Site 700 is comparable to that at nearby Site 699 . The only difference between the two sites is that at the latter species diversity is lower in the uppermost lower Eocene and decreases earlier in middle Eocene Zone P10.

Paleomagnetic analyses carried out at Site 700 provide correlation points for the Paleocene (Ciesielski, Kristoffersen, et al., 1988; Hailwood and Clement, this volume). Paleocene Sample 114-700B-36R-2, 68-70 cm, which belongs to Zone
P1b and contains "Subbotina" pseudobulloides, falls within Chron 29N, and the FO of "Morozovella" uncinata, which equates to the base of Zone P2, occurs just below the boundary between Chrons $27 \mathrm{~N}$ and 26R (63.14 Ma). For additional calibration of Paleocene foraminifer datums to the paleomagnetic record of Hole 700B, see Hailwood and Clement (this volume).

\section{Site 701}

Site 701 was drilled on the western flank of the MidAtlantic Ridge, about $160 \mathrm{~km}$ east of the Islas Orcadas Rise on oceanic crust of middle Eocene age. The major object- 
Table 2 (continued).

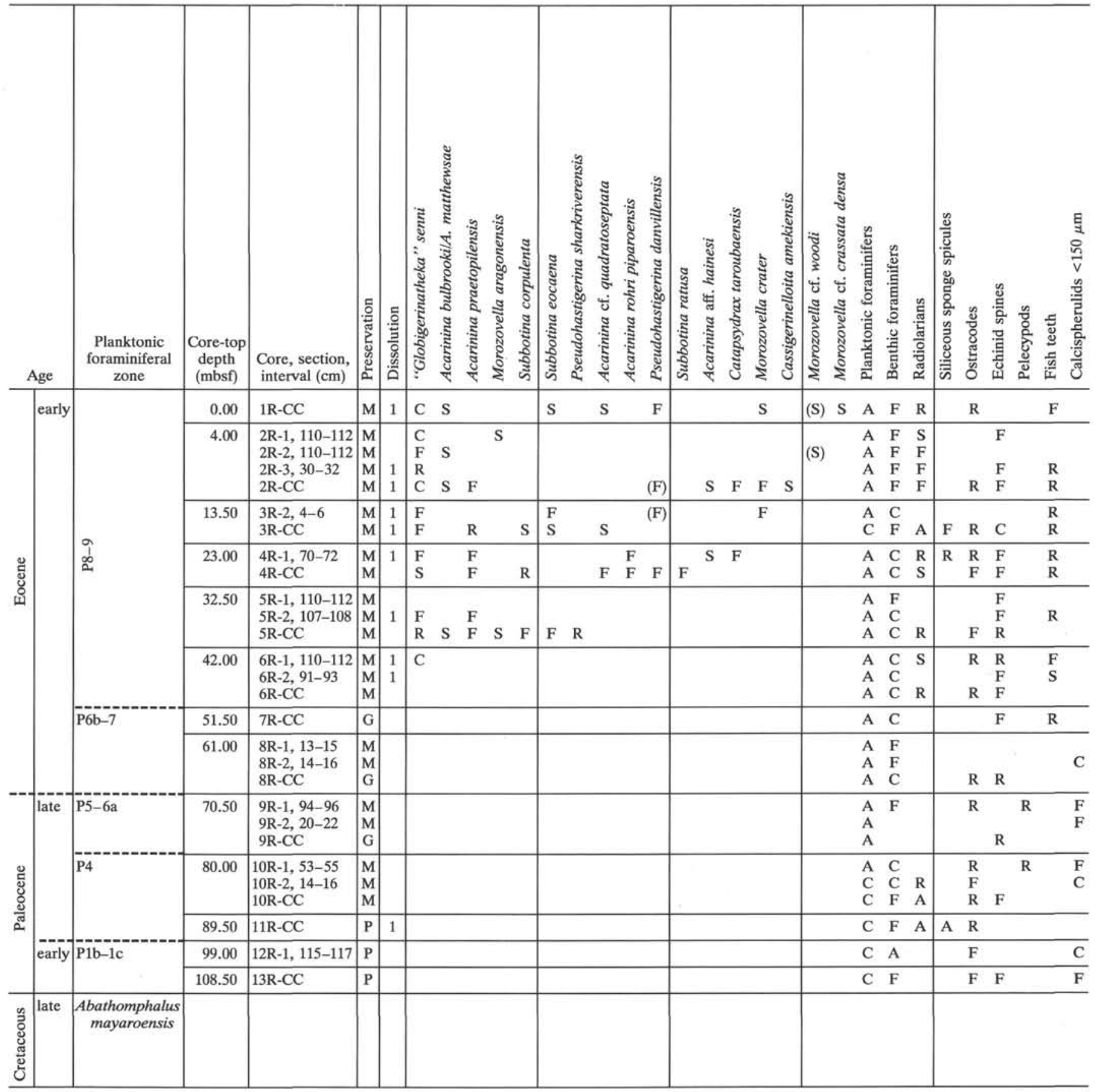

Note: Abundance: $\mathrm{S}=$ very rare or single specimen $; \mathrm{R}=$ rare $; \mathrm{F}=$ few $; \mathrm{C}=$ common; $\mathrm{A}=$ abundant. Preservation: $\mathrm{G}=$ good; $\mathrm{M}=$ moderate $\mathrm{P}=$ poor. Dissolution: blank = test without etching of chambers; $1=$ slight to medium etching of chambers; $2=$ strong etching of chambers; $3=$ most specimens broken. Also, $\mathrm{r}=$ reworked; ? = doubtful occurrents; ()$=$ specimens occur only in the $<150-\mu \mathrm{m}$ size fraction.

ive of this site was to obtain a continuous sediment record of the development of an oceanic gateway for deep circulation between the South Atlantic and the Weddell Basin.

The sequence is about $480 \mathrm{~m}$ thick, spanning the early middle Eocene (Zone P10-base Zone P11) to the Pleistocene; the 100 -m-thick lower part is Paleogene in age. Carbonate biofacies are restricted to a $70-\mathrm{m}$ section at the bottom of the sequence. Uphole, the sediments grade from indurated nannofossil chalk with an average carbonate content of $80 \%$ to an alternation of nannofossil oozes, siliceous oozes, and clays. Upward, only siliceous biofacies occur.

Planktonic foraminifers are abundant and moderately preserved only in the lowermost 5 -m-thick sediment section, between Samples 114-701C-49X-CC and 114-701C-49X-3, $135-137 \mathrm{~cm}$. A distribution chart and synthetic logs, therefore, were not constructed because of the few samples containing planktonic foraminifers.

The assemblages contain rare Acarinina pseudotopilensis, Acarinina bullbrooki, Acarinina spinuloinflata, "Morozo- 


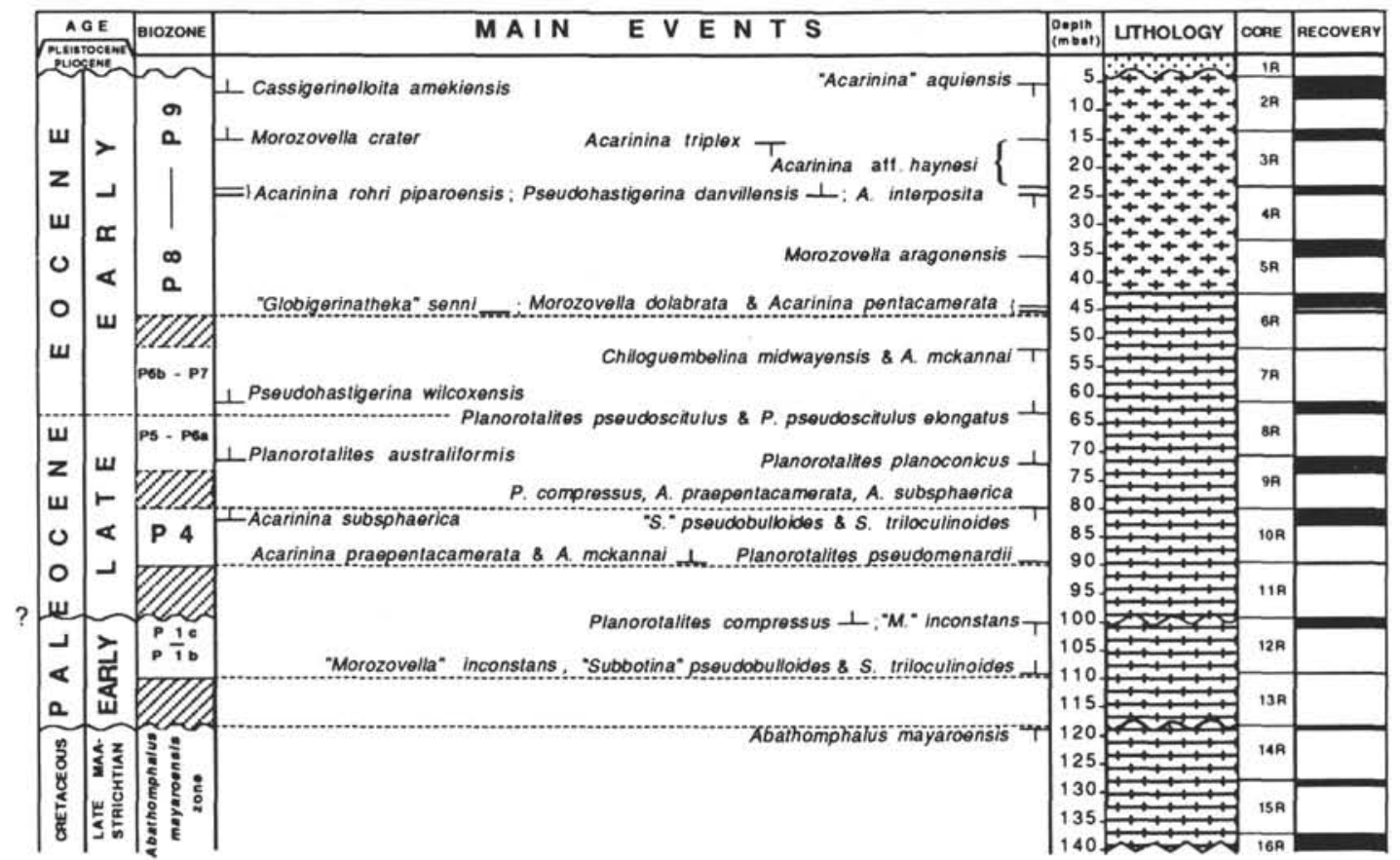

Figure 3. Paleogene planktonic foraminiferal zonation, Hole 698A.

vella" cf. broedermanni, biconvex morozovellids, very abundant Acarinina primitiva, abundant Subbotina patagonica, Subbotina eocaenica irregularis, Subbotina eocaena, common Planorotalites, Pseudohastigerina micra, Pseudohastigerina danvillensis, and few Cassigerinelloita amekiensis. This planktonic foraminiferal assemblage indicates an early middle Eocene age (Zone P10-lower part of Zone P11). The occurrence of $C$. amekiensis, which disappears in Zone P10 at the other sites, and the age based on calcareous nannofossils (Zone NP15) would restrict the age of the bottom of the section to the middle upper part of Zone P10. In fact, foraminiferal Zone P10 is reported to overlap with nannofossil Zone NP15 only in its upper part. Above this level planktonic foraminifers become very rare and are represented by only the solution-resistant species $A$. primitiva, which persists up to Sample 114-701C-49X-1, 135-137 cm. The last rare planktonic foraminifers are represented by fragments of unidentified globigerinid tests, which disappear in Sample 114-701C-48XCC (443 mbsf).

From the early middle Eocene, when the water depth at Site 701 was clearly above the foraminiferal lysocline, dissolution increased in such a way as to fragment, and then destroy completely, the foraminiferal tests from a $30-40-\mathrm{m}$ section of sediments. The foraminiferal lysocline was definitely above the seafloor during the late Eocene. The low species diversity in the last samples, as mentioned previously, is interpreted as due to dissolution.

A hiatus detected between the middle and the late Eocene on the basis of calcareous nannoflora (Crux, this volume) could explain the absence of Globigerinatheka index, a solution-resistant species, at Site 701. Planktonic foraminiferal assemblages are too depleted for any further interpretation.

The sequence of siliceous-bearing clay of Oligocene age, with a hiatus between the early and late Oligocene, is very thin in comparison with the thick Oligocene sequence recorded at Site 699 (approximately $50 \mathrm{~m}$ at Site $701 \mathrm{vs.} \mathrm{approximately} 200$ $m$ at Site 699). This would suggest that deep erosional currents were strongly active at the location of Site 701 during the Oligocene.

The contribution of planktonic foraminifers to the history of this important gateway area is limited to the initial phase of sedimentation, dated as early middle Eocene and at a water depth of less than $3000 \mathrm{~m}$.

\section{Site 702}

Site 702 is located on the central part of the Islas Orcadas Rise, a north-northwest-trending aseismic ridge more than $1000 \mathrm{~m}$ above the adjacent seafloor. The Islas Orcadas and Meteor rises were conjugate features prior to seafloor spreading that separated them in the Eocene. One of the major objectives of this site was to investigate the influence of the shallow Islas Orcadas and Meteor rises on oceanic water-mass communication between the southern high-latitude region and the South Atlantic.

At Site 702 the sedimentary sequence is represented essentially by pelagic carbonates, $273 \mathrm{~m}$ thick, ranging in age from late Paleocene (Zone P3) to late Eocene, topped by a $22-\mathrm{m}-$ thick section of diatom muds and nannofossil and siliceous oozes, ranging in age from late Miocene to Pleistocene.

Paleogene sediments grade from indurated chalks with interbedded cherts in the lower part upward to chalks and nannofossil oozes. The carbonate content is consistently between $88 \%$ and $95 \%$. Clay is present only at the bottom of the sequence, attributed to the lower part of Zone P3, where the carbonate content is lower also (mean value of $60 \%$ ). In the clay-rich interval radiolarians are more abundant than planktonic foraminifers (Figs. 9 and 10). In late Paleocene Zone P4 planktonic foraminifers seem to be more abundant in comparison with the other sites, but the poor recovery can be misleading. Above the clayey layer of Zone P3, planktonic foraminifers are abundant and dominate throughout, whereas radiolarians are absent in the lower Eocene. Radiolarians reappear again in the lower middle Eocene, but they are never abundant except at two levels in the upper Eocene. 


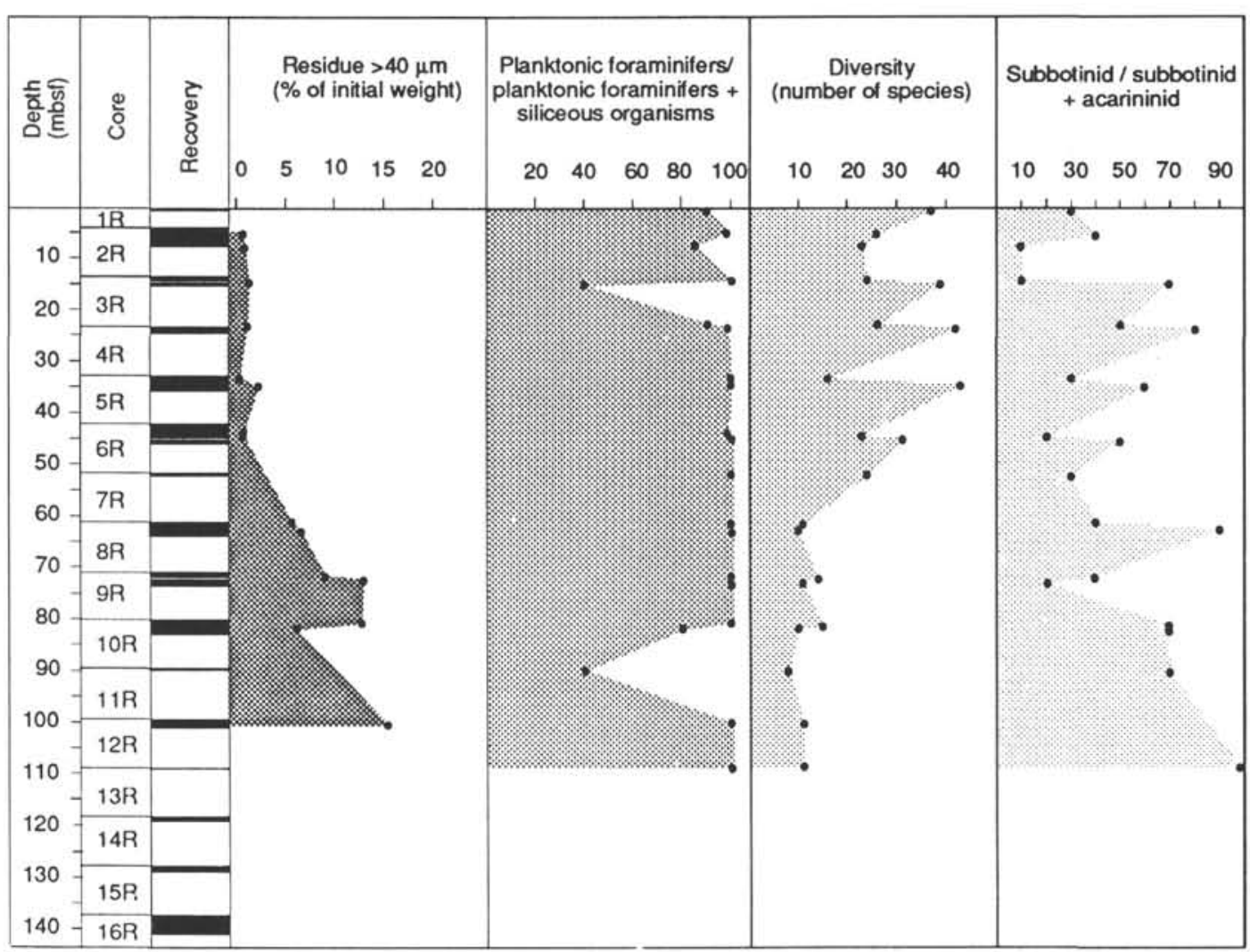

Figure 4. Selected parameters plotted against depth to depict changes in biofacies deposition at Hole 698A.

Planktonic foraminifers are poorly preserved in the lower part of the sequence, due to the diagenetic processes of compaction, and moderately well preserved upward. Heavy etching of chambers is observed only in the uppermost middle Eocene and upper Eocene, but planktonic foraminifers are always abundant.

On the whole, the bulk of the carbonate sediments deposited during the Paleogene indicates uniform environmental conditions and biogenic accumulation always well above the foraminiferal lysocline. According to benthic foraminifers the water depth at Site 702 changed from $1600 \mathrm{~m}$ by early late Paleocene to about $2000 \mathrm{~m}$ in the early middle Eocene (Katz and Miller, this volume).

Species diversity was high from the late Paleocene onward, reaching the maximum number of species in the late early Eocene; from the early middle Eocene mean species diversity decreased and fluctuated (Fig. 10). Although calcareous biofacies exhibit some degree of dissolution associated with the decrease in species diversity beginning in early middle to late Eocene, dissolution effects are much less evident than at Sites 699 and 700 .

Good paleomagnetic signals allow us to calibrate several events that have been used to identify the standard biozonation (see correlation by Berggren et al., 1985). According to Ciesielski, Kristoffersen, et al. (1988) and Clement and Hailwood (this volume), the following chrons could be recognized:

157 mbsf within Core 114-702B-17X: Chron 21N/20R boundary (48.75 Ma), which falls within the basal part of Zone P11;

113 mbsf within Core 114-702B-13X: Chron 20R/20N boundary $(46.17 \mathrm{Ma})$, which correlates with the P11/12 zonal boundary;

98.70 mbsf within Core 114-702B-11X: Chron 20N/19R boundary (44.66 Ma), which falls within Zone P12;
86.50 mbsf within Core 114-702B-10X: Chron 19R/19N boundary (44.06 Ma), which falls within Zone P12;

84.76 mbsf within Core 114-702B-10X: Chron 19N/18R boundary (43.60 Ma), which still falls within Zone P12; and

71.9 mbsf within Core 114-702B-8X: Chron $18 \mathrm{R} / 18 \mathrm{~N}$ boundary (42.73 Ma), which straddles the Zone P12-13/P14 boundary.

At 154 mbsf, just above the Chron 21N/20R boundary, the planorotalitids disappear; thus their local last occurrence is an early P11 zonal event. Between 113.72 and $115.20 \mathrm{mbsf}$ (46.19-46.28 Ma), less than $2 \mathrm{~m}$ below the Chron $20 \mathrm{R} / 20 \mathrm{~N}$ boundary, the FO of Globigerinatheka index is a late P11 zonal event. Within Chron $20 \mathrm{~N}$, and thus in the lower part of Zone P12, the biconvex morozovellids and the previously common Guembelitria disappear, while Acarinina bullbrooki disappears (44.13-43.99 Ma) about $5 \mathrm{~m}$ above them. Close to the Chron $18 \mathrm{R} / 18 \mathrm{~N}$ boundary, which is just below the P13/14 zonal boundary, the disappearance of "Globigerinatheka" senni and Pseudohastigerina danvillensis is recorded. In the uppermost part of Zone P12, as here inferred, common Subbotina linaperta occurs. Very rare specimens of $S$. linaperta are recorded much earlier in the sequence (lower part of Zone P12) (Table 5, back pocket). At Site 702 the LO of Acarinina primitiva occurs about $24 \mathrm{~m}$ above the Chron $18 \mathrm{R} / 18 \mathrm{~N}$ boundary, thus much higher than the P13/14 zonal boundary. Consequently, the LO of A. primitiva cannot be a P13 zonal event, as suggested by Edwards and Hoskins (1982), being very close, if not coincident, with the P14/15 zonal boundary at Site 702 .

A few reworked Cretaceous Globigerinelloides and Heterohelix were found in late Paleocene and early Eocene age strata.

Major hiatuses are not present in the Paleogene, but minor hiatuses between the upper Paleocene and lower Eocene and 


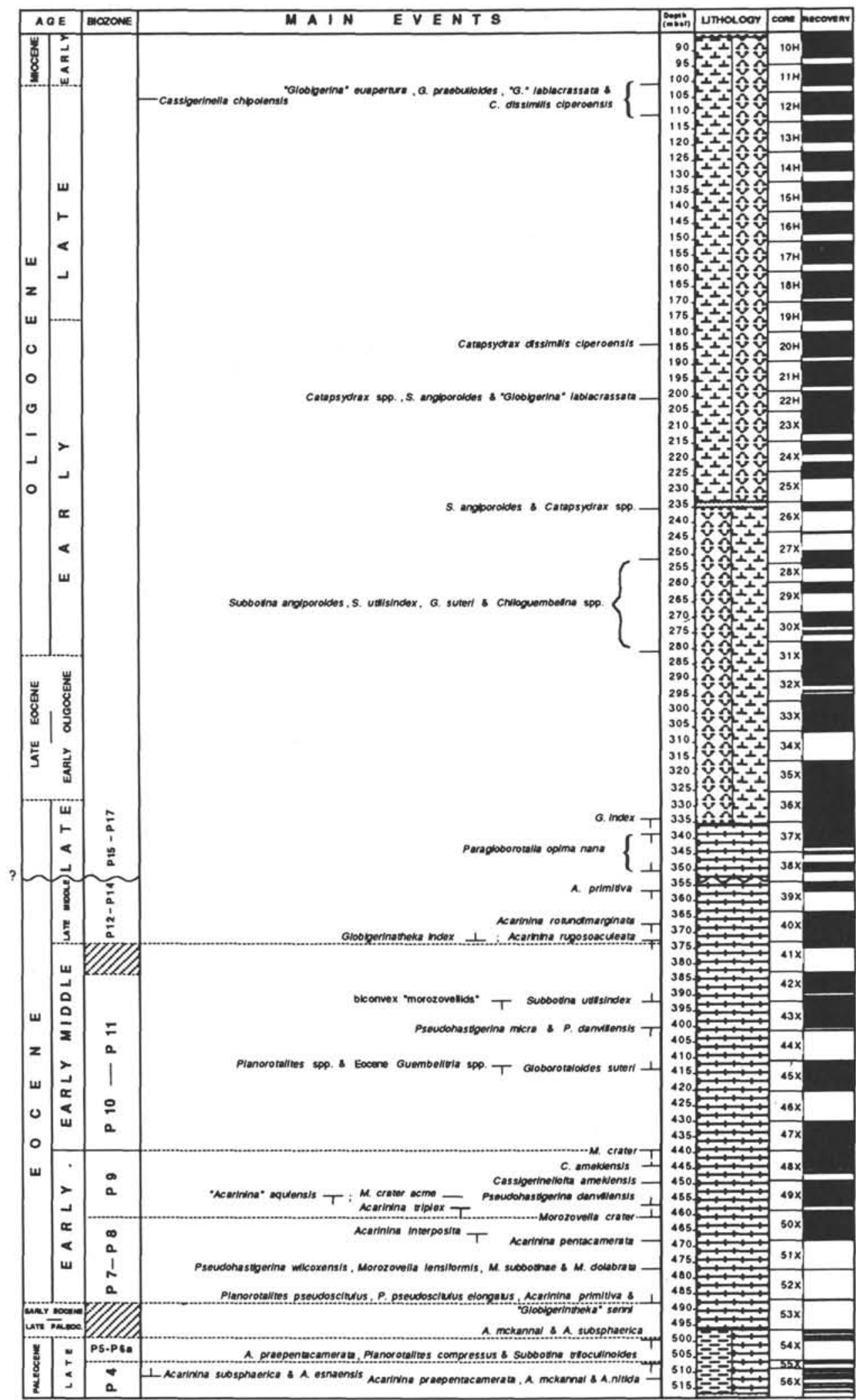

Figure 5. Paleogene planktonic foraminiferal zonation, Hole 699A. 


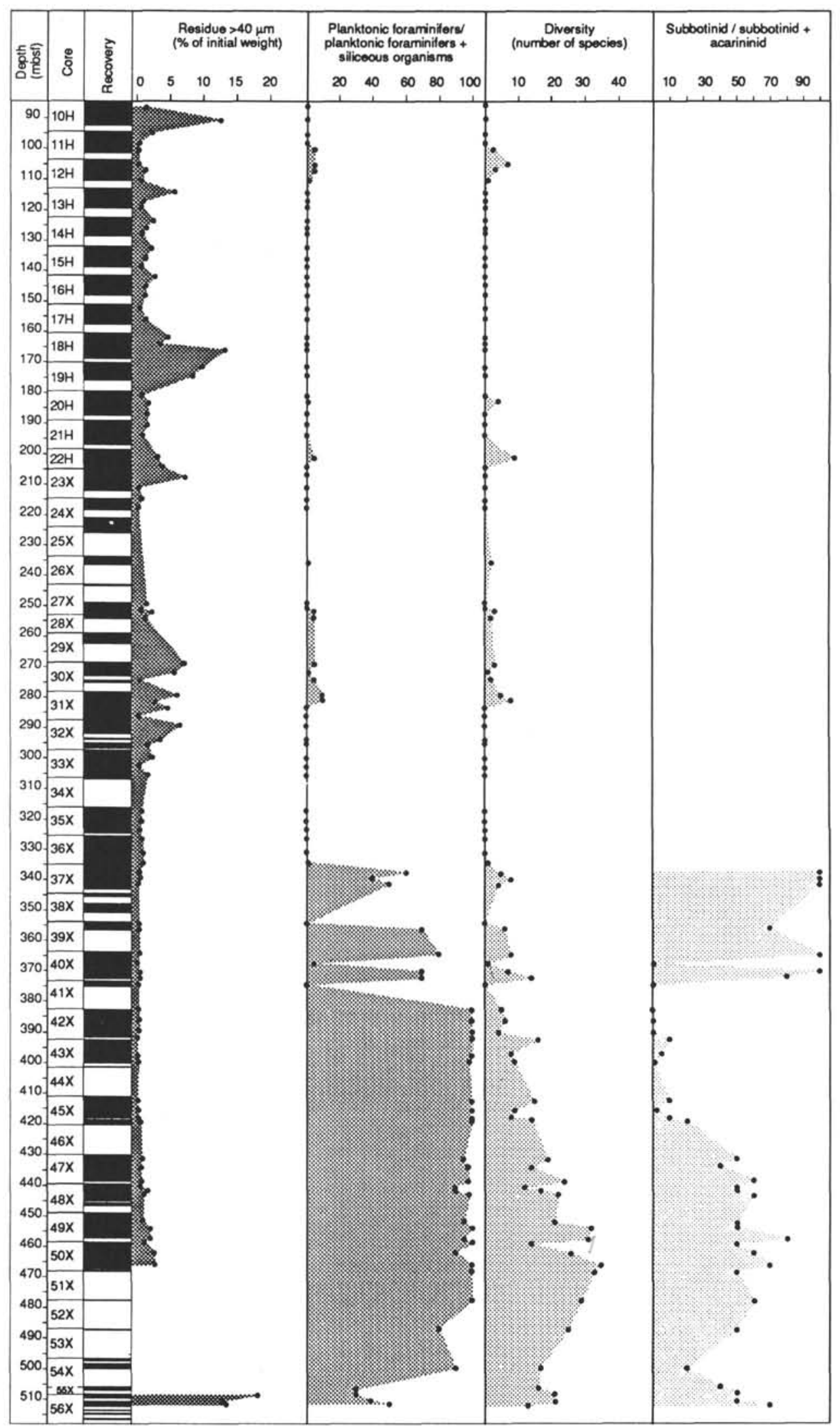

Figure 6. Selected parameters plotted against depth to depict changes in biofacies deposition at Hole 699A. 


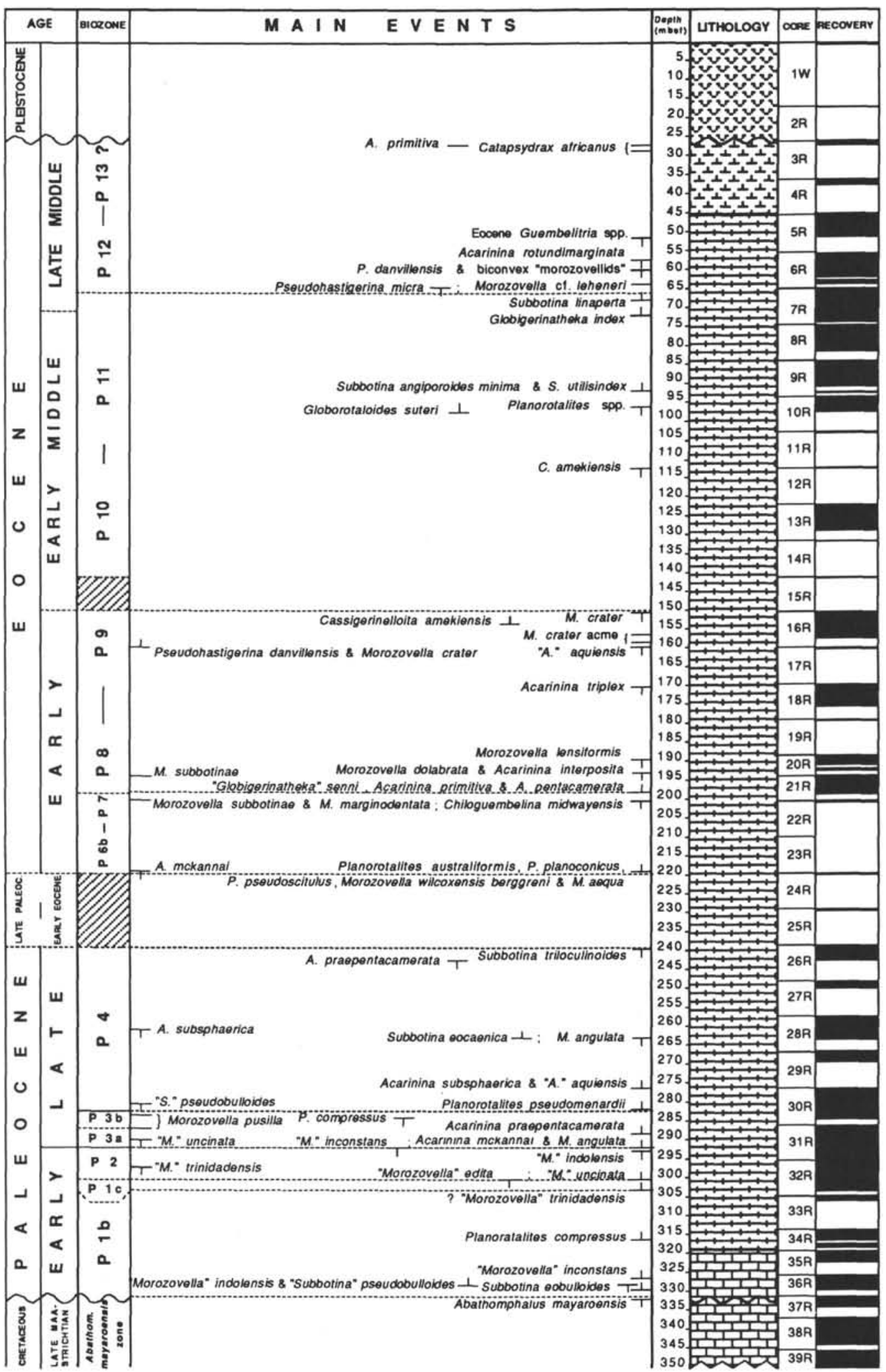

Figure 7. Paleogene planktonic foraminiferal zonation, Hole 700B. 


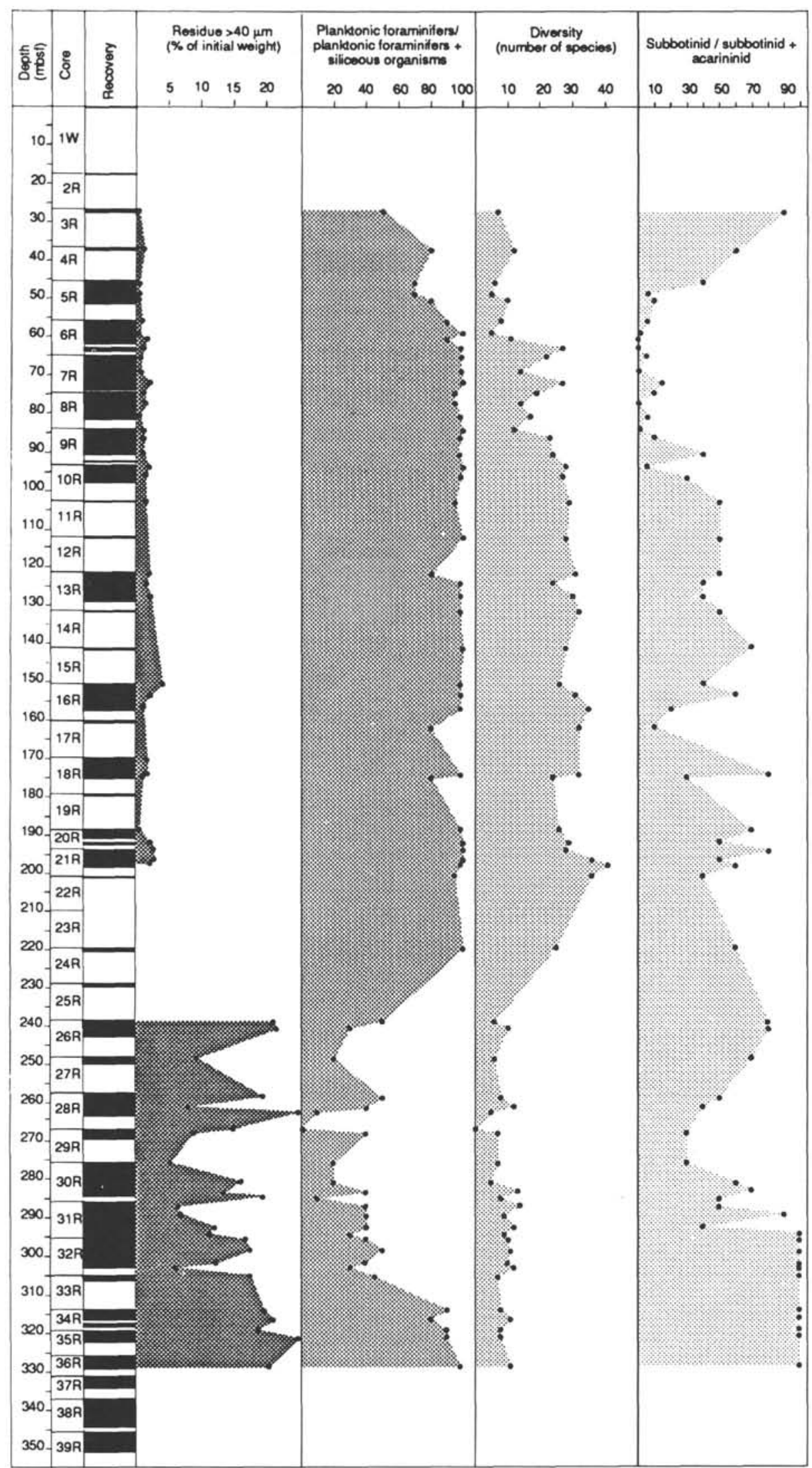

Figure 8. Selected parameters plotted against depth to depict changes in biofacies deposition at Hole 700B. 
between Zones P7 and P8 cannot be ruled out due to poor recovery. A hiatus occurring at the lower/middle Eocene boundary has removed most of Chron 21R (Clement and Hailwood, this volume). A major hiatus truncates the Paleogene section at the level of Zone P15 or basal Zone P16 (nannofossil Zone NP18), identified on the basis of the occurrence of small round-chambered acarininids (see "Biostratigraphy" section). The Morozovella crater Zone spans $20 \mathrm{~m}$ of sediments at this site.

In Figure 10, S/SA ratio was plotted separately for the size fractions $<150$ and $>150 \mu \mathrm{m}$. In the lower Eocene up to Zones P11/12, the acarininids are more abundant and diversified than the subbotinids in the finer fraction without domination by any species. By the upper middle Eocene the acarininids increase in abundance in the size fraction $>150 \mu \mathrm{m}$, mainly because of the dominance of the large species $A$. primitiva. Considering both size fractions, the acarininids are abundant up to the middle to upper Eocene boundary.

The generally good preservation of planktonic foraminifers and the completeness of the Paleogene record at least up to the upper Eocene at Site 702 suggest that this site is the most suitable for biogeographic and paleoceanographic reconstructions.

\section{Site $\mathbf{7 0 3}$}

Site 703 was drilled on Meteor Rise, an aseismic ridge extending southwest from the Agulhas Fracture Zone. This

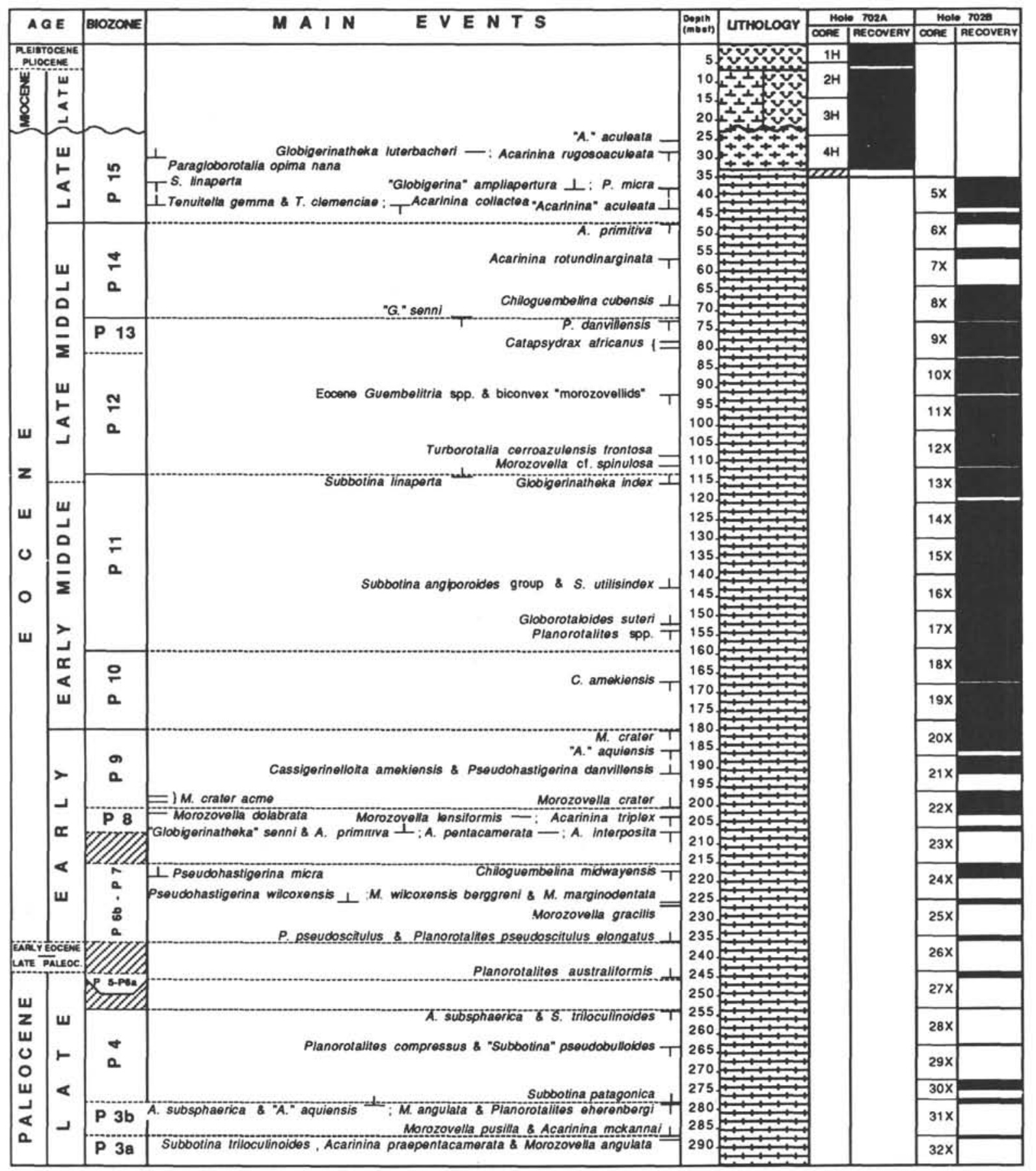

Figure 9. Paleogene planktonic foraminiferal zonation, Holes 702A and 702B. 


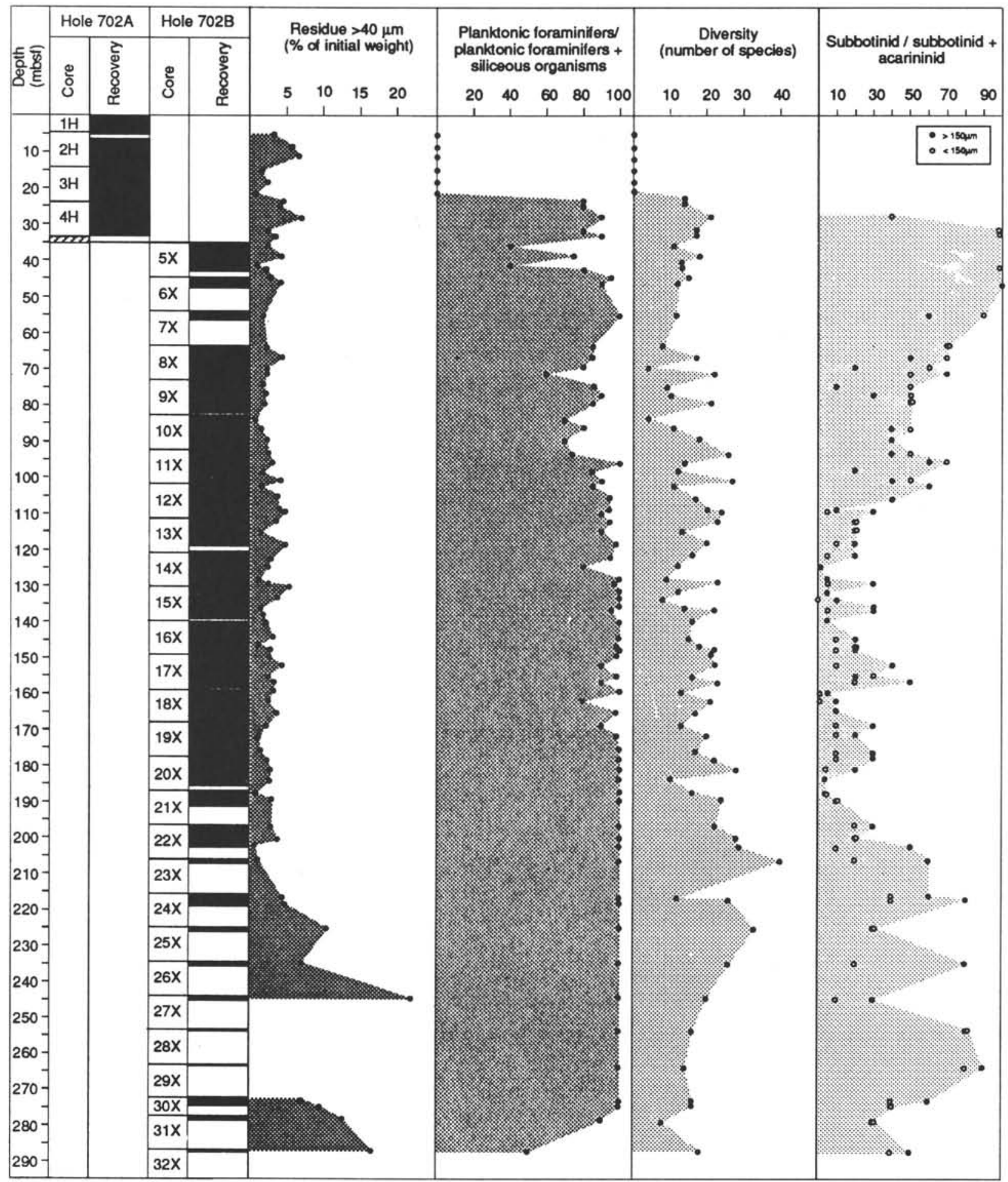

Figure 10. Selected parameters plotted against depth to depict changes in biofacies deposition at Holes 702A and 702B.

site is presently located between the Subtropical Convergence and the Antarctic Convergence Zone, the northern edge of which is about $2.5^{\circ}$ south of Site 703 . One of the major objectives of this site was to investigate the influence of the shallow Paleogene Meteor Rise, Islas Orcadas Rise, and the adjacent fracture zone on the oceanic communication between high and temperate latitudes in the South Atlantic.

At Site 703 the 377-m-thick sedimentary sequence consists predominantly of calcareous biogenic sediments, middle
Eocene to Pleistocene in age, resting on volcanic rocks. However, significant biosiliceous input occurred in the late Eocene, late Oligocene, and early Miocene, and mass-flow deposits are common throughout the middle Eocene. The Paleogene section represents almost eight-ninths of the entire sequence. In the lowest part of the section, recovery was poor and discontinuous (Fig. 11). The common drilling disturbances are due to the occurrence of extremely variable lithotypes, including gravelly volcanic sand, volcanic brec- 


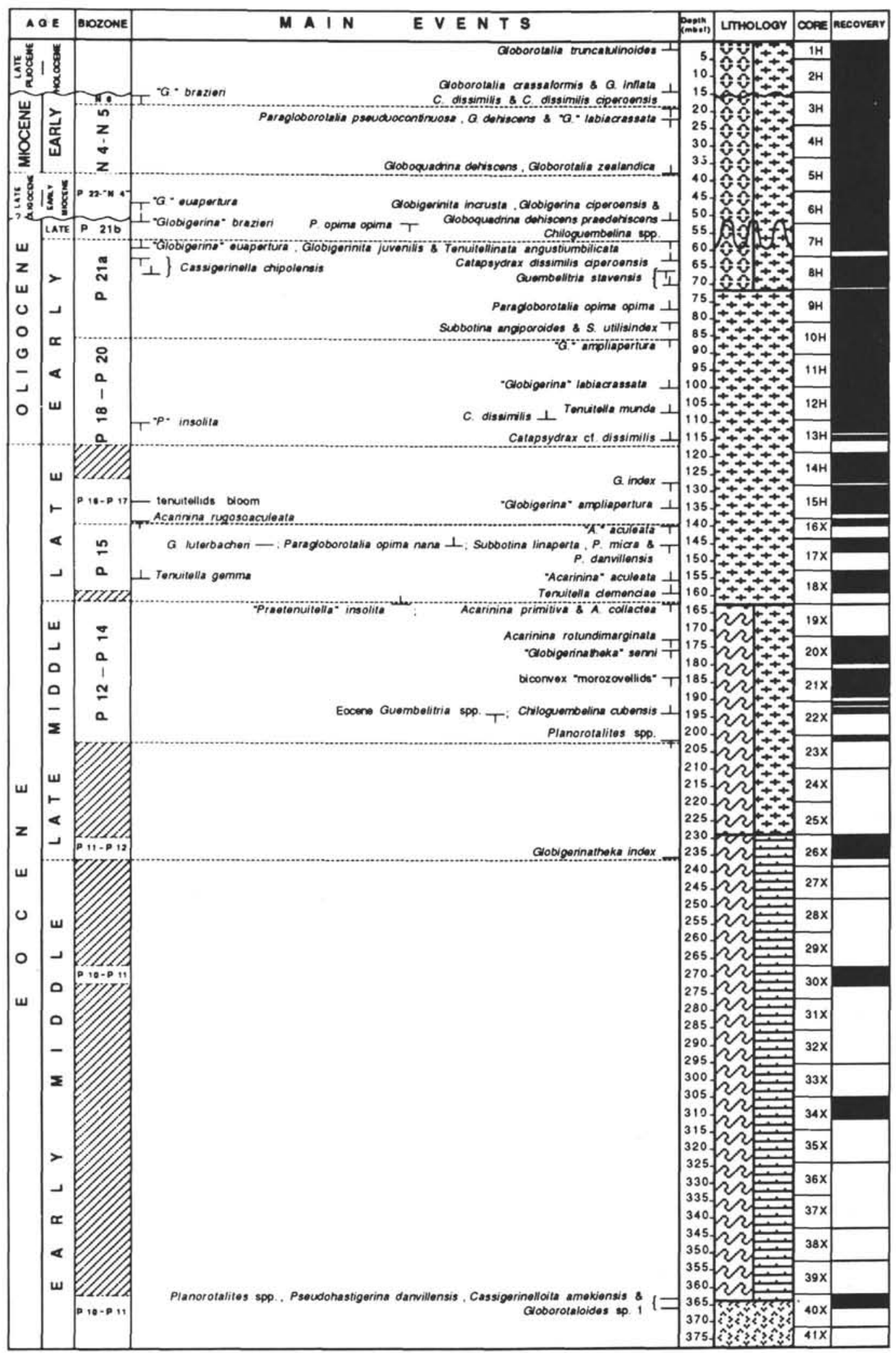

Figure 11. Paleogene planktonic foraminiferal zonation, Hole 703A. 
cias, chert, basalt, quartz and granodiorite fragments, and minor amounts of nannofossil chalk. Higher in the sequence (above $250 \mathrm{mbsf}$ ) the main lithotypes are nannofossil oozes containing mass-flow deposits of clay, sand, gravel, and volcanic breccias, replaced by siliceous, foraminifer-bearing nannofossil oozes in the uppermost part. The carbonate content is $0 \%$ in the lowest part and increases abruptly above 300 mbsf; from this level upward $\mathrm{CaCO}_{3}$ content is high on average ( $80 \%)$. Lower carbonate content reflects the presence of noncarbonate components, such as volcanic ash and siliceous organisms, which are more abundant in residues $>40$ $\mu \mathrm{m}$ (Fig. 12).

Intensive downhole contamination of planktonic foraminifers occurs in the bottom core, where well-preserved planktonic foraminifers are extremely abundant and of mixed ages, although the differences in age of the various taxa are minor. Above Core 114-703A-23X (200 mbsf) planktonic foraminifers are abundant to common throughout the remaining Paleogene sequence except for some lower Oligocene levels where few planktonic foraminifers were recovered (see Table 6, back pocket, and Fig. 12). In the upper middle Eocene planktonic foraminifers are more abundant than siliceous organisms, but by the upper Eocene through the Oligocene-lower Miocene radiolarians become a significant component of the microfaunas (Fig. 12).

Planktonic foraminifers are variably preserved throughout the Paleogene sequence. Foraminiferal tests are well preserved without signs of dissolution in Core 114-703A-40X at the bottom of the hole in the upper middle Eocene, alternatingly slightly to strongly dissolved in the uppermost middle Eocene and upper Eocene, and strongly dissolved in the lower Oligocene. Foraminiferal preservation improves upsection in the upper Oligocene Subzones P21a and P21b and in the interval attributed to Zones P22-"N4," where planktonic foraminifers are only slightly recrystallized. Preservation becomes poor again later in the lower Miocene.

Overall at Site 703 dissolution is not only extremely variable, but is also randomly distributed through the section. It does not, however, affect species diversity except in the early Oligocene assemblages. Dissolution affects the sediments differently than at Site 699.

On the basis of the good to moderate preservation of the faunas at the bottom of the hole, the early middle Eocene sedimentary depositional environment was well above the foraminiferal lysocline. In contrast to the inferred deepening of the CCD in the South Atlantic Ocean from the early Eocene to late Oligocene (van Andel, 1975), at Site 703 the occurrence of dissolved sediments from upper middle Eocene, at least partially, and especially in the lower Oligocene must be attributed to other causes independent of depth. This is corroborated by the succession of regularly spaced bioevents in the upper middle and upper Eocene that is strictly comparable with that from Site 702 , which is supposed to have remained at an almost constant water depth.

From middle Eocene Core 114-703A-18X upward diatoms are recorded in the $\mathrm{HCl}$-insoluble residue, even when they are not visible in washed residues. Between Cores 114-703A-20X and $114-703 \mathrm{~A}-32 \mathrm{X}$ (170 to $230 \mathrm{mbsf})$ they were possibly present, but are now completely dissolved, as suggested by the occurrence of clinoptilolite in the silty fraction. Therefore, we suggest that the dissolution of planktonic foraminifers (generally few in the size fraction $>150 \mu \mathrm{m}$ ) could have increased during episodes of increasing siliceous productivity or for climatic reasons (Boersma, 1977).

Downhole contamination at the bottom (Core 114-703A$40 \mathrm{X})$ proved to be quite useful in indicating the character and ages of planktonic foraminiferal faunas from a portion of the sequence that was either poorly or not recovered.
At Site 703 reworking of planktonic foraminifers, especially pronounced in the lower Miocene, is indicated by the common occurrence of middle Eocene taxa such as Acarinina primitiva, Acarinina rotundimarginata, Acarinina rugosoaculeata, Globigerinatheka index, the pseudohastigerinids, the planorotalitids, and in minor amounts, Oligocene forms (possibly the chiloguembelinids and Paragloborotalia opima opima) found in Zone P22-"N4" and in the lower Miocene.

Reworking during the middle Eocene is uncertain. Some Planorotalites have been found above the FO of $G$. index. At the studied sites west of Mid-Atlantic Ridge, the planorotalitids are reported to disappear earlier than the FO of $G$. index, which was also paleomagnetically calibrated. Thus, the planorotalitids could be reworked when mass flows were redeposited. Alternatively, because Site 703 is located at a lower latitude than that of the other sites (Table 1), Planorotalites could be in place, ranging up to the middle/late Eocene boundary, as it does in middle and low latitudes.

As evidenced by the terrigenous and siliceous input, the occurrence of mass flows, and common reworking of planktonic foraminifers, the environment at Site 703 could be characterized as rather unstable because of either upslope erosional events or strong bottom currents. This is in contrast with the quieter deposition on the western sites.

Several hiatuses inferred from siliceous phytoplankton and paleomagnetic data (Hailwood and Clement, this volume) are not easily detectable at this site on the basis of planktonic foraminifers as a result of reworking and mass slides.

In the middle Eocene species diversity is high (about 25 on average) and rather constant, with fewer fluctuations than at Site 702. While diversity fluctuates more in the upper Eocene, species diversity is always $>10$. In the lower Oligocene species diversity shows the lowest value, about 10 , whereas it markedly increases in the upper Oligocene-lower Miocene (Fig. 12).

The acarininids increase in abundance in Core 114-703A$21 \mathrm{X}$, attributable to Zone P12, where the last biconvex morozovellids occur, and then they drastically decrease after the $A$. primitiva extinction. Only a few small, round-chambered acarininids persist into the upper Eocene with the same trend as at Site 702.

On the basis of paleomagnetic data (Hailwood and Clement, this volume) the Eocene/Oligocene boundary is estimated to occur at about 122 mbsf via correlation to the Umbrian sequences (Nocchi et al., 1986). Above the inferred Eocene/ Oligocene boundary we recorded the FO of small-sized specimens named Catapsydrax cf. dissimilis and the LO of "Praetenuitella" insolita.

Because the paleomagnetic data above Chron $12 \mathrm{~N}$ are somewhat difficult to interpret and because of the mixed nature of planktonic foraminiferal faunas, most of the correlations between biostratigraphic events and magnetic data within the Oligocene interval should be considered tentative.

Subbotina angiporoides and Subbotina utilisindex, which should fall within the lower part of Zone 21a, disappear in Sample 114-703A-9H-CC ( $81 \mathrm{mbsf})$, about $2.5 \mathrm{~m}$ below a proposed hiatus between Chrons $11 \mathrm{~N}$ and 9R. P. opima opima first occurs immediately above the Chron $9 \mathrm{R} / 11 \mathrm{~N}$ hiatus; however, its FO must be younger than the base of Chron $11 \mathrm{~N}$ and it should be considered an immigrant.

The chiloguembelinids strongly decrease in abundance between Samples 114-703A-8H-2, 130-132 cm, and 114-703A$8 \mathrm{H}-1,130-132 \mathrm{~cm}$, and disappear at Sample 114-703A-7H-4, $124-126 \mathrm{~cm}$. Diatoms and paleomagnetic data suggest that a hiatus may be present at or near the level of the chiloguembelinid's strong decrease, separating Chron $9 \mathrm{~N}$ from Chron $8 \mathrm{~N}$ (Hailwood and Clement, this volume). According to this 


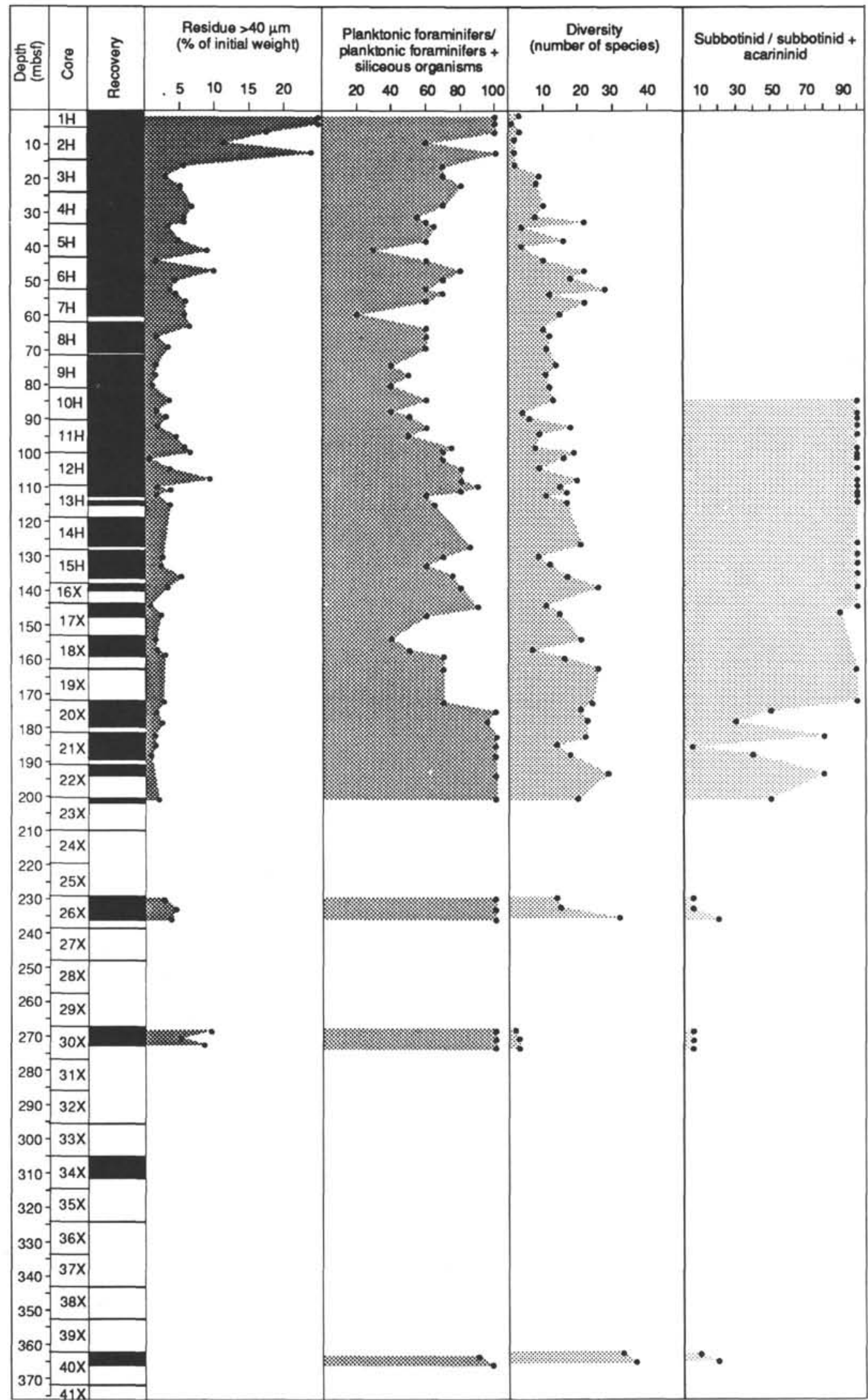

Figure 12. Selected parameters plotted against depth to depict changes in biofacies deposition at Hole 703A. 


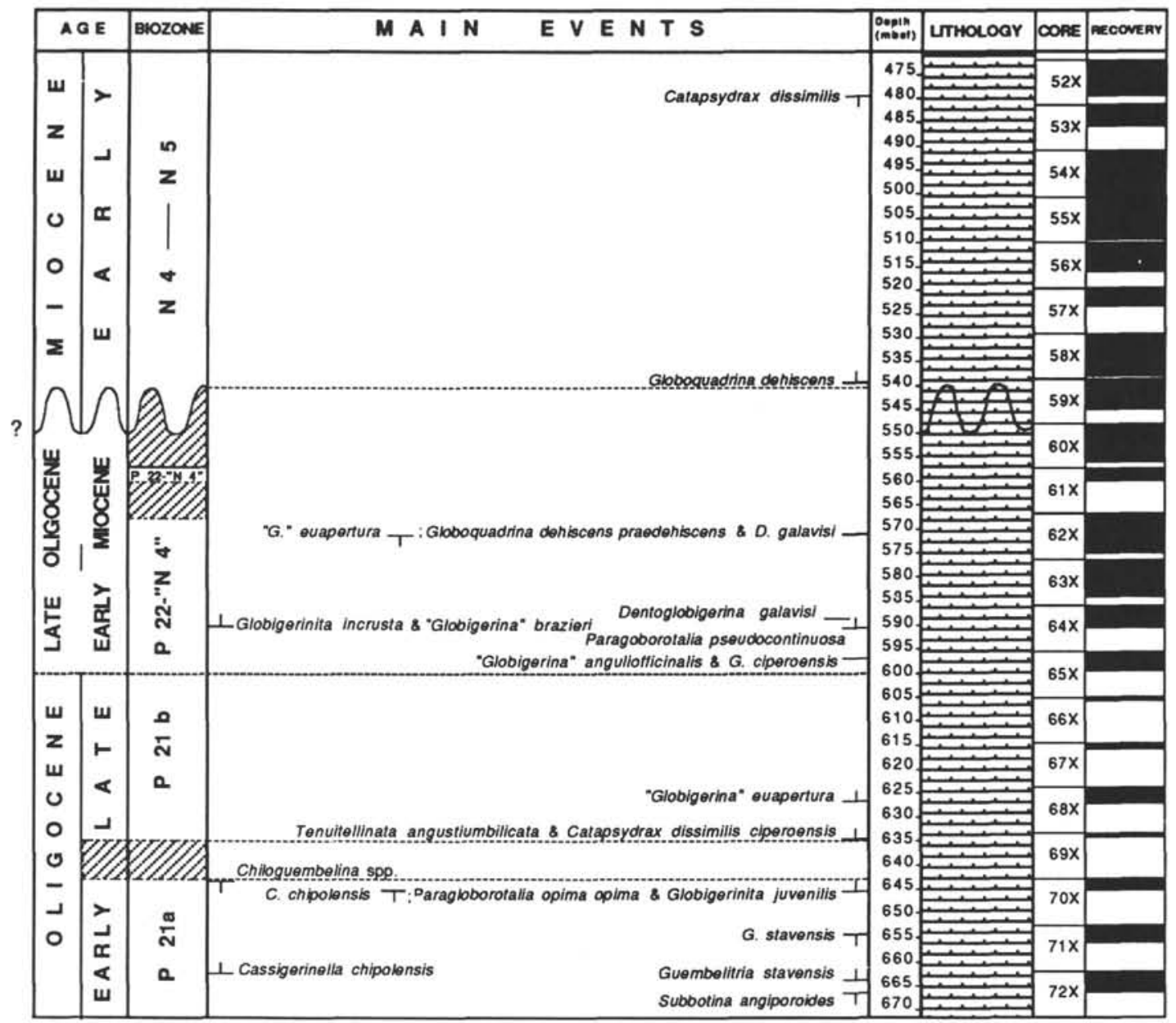

Figure 13. Paleogene planktonic foraminiferal zonation, Hole 704B.

interpretation the $\mathrm{P} 21 \mathrm{a} / 21 \mathrm{~b}$ zonal boundary, based on chiloguembelinid extinction, is considered uncertain and chiloguembelinids might be reworked above Sample 114$703 \mathrm{~A}-8 \mathrm{H}-2,130-132 \mathrm{~cm}$.

\section{Site 704}

Site 704 was drilled on the southern part of the Meteor Rise, between the present Subtropical Convergence and the Antarctic Convergence Zone. This site was located on a region of the Meteor Rise where a maximum thickness of Neogene and upper Paleogene sediments could be obtained in order to provide a high-resolution paleoceanographic-paleoclimatic record of an interval not well represented at the previous Leg 114 sites.

A 670 -m-thick mixed carbonate and biosiliceous sequence, of early Oligocene to Pleistocene age, was obtained at Site 704. The Paleogene portion ( $120 \mathrm{~m}$ thick) represents only about one-fifth of the entire sequence and consists of indurated micritic nannofossil chalks, with little variation in lithology, grading to nannofossil chalks in the lower Miocene. Within the Oligocene, pelagic carbonate sediments predominate, with a $\mathrm{CaCO}_{3}$ content up to $80 \%$ on average.

Planktonic foraminifers are abundant in the lower Oligocene up to Zone P21a, become rare to few in the middle of Zone P21b, and then increase again in abundance upward. Radiolarians and other siliceous organisms are always common to abundant in washed residues, although their occur- rence is not mentioned in the lithologic description (Ciesielski, Kristoffersen, et al., 1988).

Preservation of planktonic foraminifers is poor, with signs of dissolution evident in the lower part of Zone P21b. Poor preservation and the decrease in planktonic foraminiferal abundance correspond to an increase in diatom abundance at about 600-650 mbsf; therefore, poor foraminiferal assemblages may be related to an increase in siliceous productivity, possibly associated with major late Oligocene climatic and oceanographic changes (e.g., Kennett, 1977, 1978; Boersma, 1977).

Reworking of planktonic foraminifers occurs at various intervals. At the bottom of the hole, in the lower part of Zone P21a, abundant forms $>300 \mu \mathrm{m}$ in size, of middle to late Eocene age, such as Acarinina primitiva, Globigerinatheka index, and Subbotina linaperta, are reworked and well sorted. This sorting can be attributed to winnowing or turbidity currents. A. primitiva and the chiloguembelinids also occur within the late Oligocene P22-"N4" zonal interval.

In the Paleogene section hiatuses are not easily recognizable on the basis of planktonic foraminifers. In the interval from Zone P21a through the P22-"N4" zonal interval we record the same succession of events as at Site 703 (Fig. 13) except that the Zone P21b is much thicker than at the previous site (about 40 vs. $<10 \mathrm{~m}$ ).

A distribution chart and diagrams were not constructed for Site 704 because of the poor preservation and reworking. The sedimentation history at Site 704 is similar, however, to that of 
the nearby, more elevated Site 703, except that the late Oligocene age sequence records a higher accumulation rate than at Site 703 .

\section{BIOSTRATIGRAPHY}

Like modern planktonic foraminifers, Paleogene planktonic foraminifers are distributed in biogeographic zones parallelling latitude. Climatically induced expansion or contraction of these zones is reflected in changing foraminiferal distributions through the Paleogene (Boersma et al., 1987). Consequently, planktonic foraminiferal assemblages recovered in Leg 114 should represent the climatic evolution of the subantarctic region.

Paleogene planktonic foraminifers from the subantarctic transect display distributions strongly dependent upon their location at high latitudes.

In general, we can distinguish two major associations among the planktonic foraminiferal assemblages recovered during Leg 114: (1) "indigenous" faunas containing species or genera that are present with some continuity after their evolutionary appearance and (2) single species or a few species per genus that display discontinuous or stratigraphically very limited ranges and that are interpreted to have immigrated into the area, usually during warm periods. The latter are called "guests," or "immigrants." Indigenous faunas display lower diversity and high to very high dominance. Faunas containing immigrants have higher species diversity and, as expected, dominance decreases.

Because the forms indigenous to high latitudes are not only cosmopolitan species, but have longer stratigraphic ranges, biostratigraphic correlation with the low-latitude standard zonation must be based mainly on the warmer immigrants. Consequently, zoning is based on event stratigraphy, not datums, which produces a higher degree of uncertainty. This is strongly amplified in those parts of the stratigraphic column characterized by very poor recovery. Nevertheless, the lower latitude standard zonation (Berggren et al., 1985) was applied, as shown in Figure 14. The applicability of such a zonation is corroborated by the paleomagnetic stratigraphy of some of the sequences and by comparison with the paleobiogeographic reconstructions of the Paleogene Atlantic Ocean. The new data are not only in agreement with, but also complement, what has already been described from the Atlantic Ocean for this interval (Boersma and Shackleton, 1977; Haq et al., 1977; Boersma and Premoli Silva, 1983; Boersma et al., 1987; Premoli Silva and Boersma, 1988).

The taxonomy used in this paper is rather informal and mainly follows that proposed by Boersma and Premoli Silva (1983) and Premoli Silva and Boersma (1988, in press). This loose taxonomy reflects the numerous unsolved questions in Paleogene taxonomy remaining from the major treatment by Blow (1979).

\section{Early Paleocene}

\section{Zone P1a-1c}

The oldest Paleocene Subzone Palpha $(=$ Planorotalites eugubinus Zone) according to the calcareous nannofossil data seems to be missing because of a hiatus (Ciesielski, Kristoffersen, et al., 1988). The other three subzones have been recognized at Sites 698 and 700 . The boundaries between them are based on the FO of the nominate taxa "Subbotina" pseudobulloides, Subbotina triloculinoides, and "Morozovella" trinidadensis, respectively. These boundaries, however, are somewhat uncertain in terms of sub-bottom depth at each site because of poor recovery.
Planktonic foraminiferal faunas are rich and diversified. The oldest P1b fauna consists of few to common chiloguembelinids $(<150 \mu \mathrm{m})$, Globoconusa daubjergensis, common Subbotina triloculinoides, few "Subbotina" fringa, common " $S$." pseudobulloides, few Planorotalites praecompressus, Tenuitella reissi, and rare "Morozovella" edita. In Zone P1c, the chiloguembelinids are larger than $150 \mu \mathrm{m}$, and more abundant "S." pseudobulloides is associated with rare "Morozovella" inconstans, few Planorotalites compressus, Subbotina imitata, Subbotina triangularis, and rare "Morozovella" indolensis. The zonal marker, "Morozovella" trinidadensis, is very rare.

\section{Zone P2}

This zone was recorded only from Site 700; its presence or absence at Site 698 cannot be proved because of poor recovery. The assemblage of Zone P2 is similar to those of the previous zones, but is characterized by common "Morozovella," the zonal marker, much rarer Globoconusa daubjergensis, small-sized chiloguembelinids $(<150 \mu \mathrm{m})$, and by the FO of "Morozovella" praecursoria. A few "Morozovella" trinidadensis are still present.

\section{Late Paleocene}

\section{Zone P3a}

In this zone, recorded at Sites 700 and 702 but again not at Site 698, the FO of Morozovella angulata, the index species,

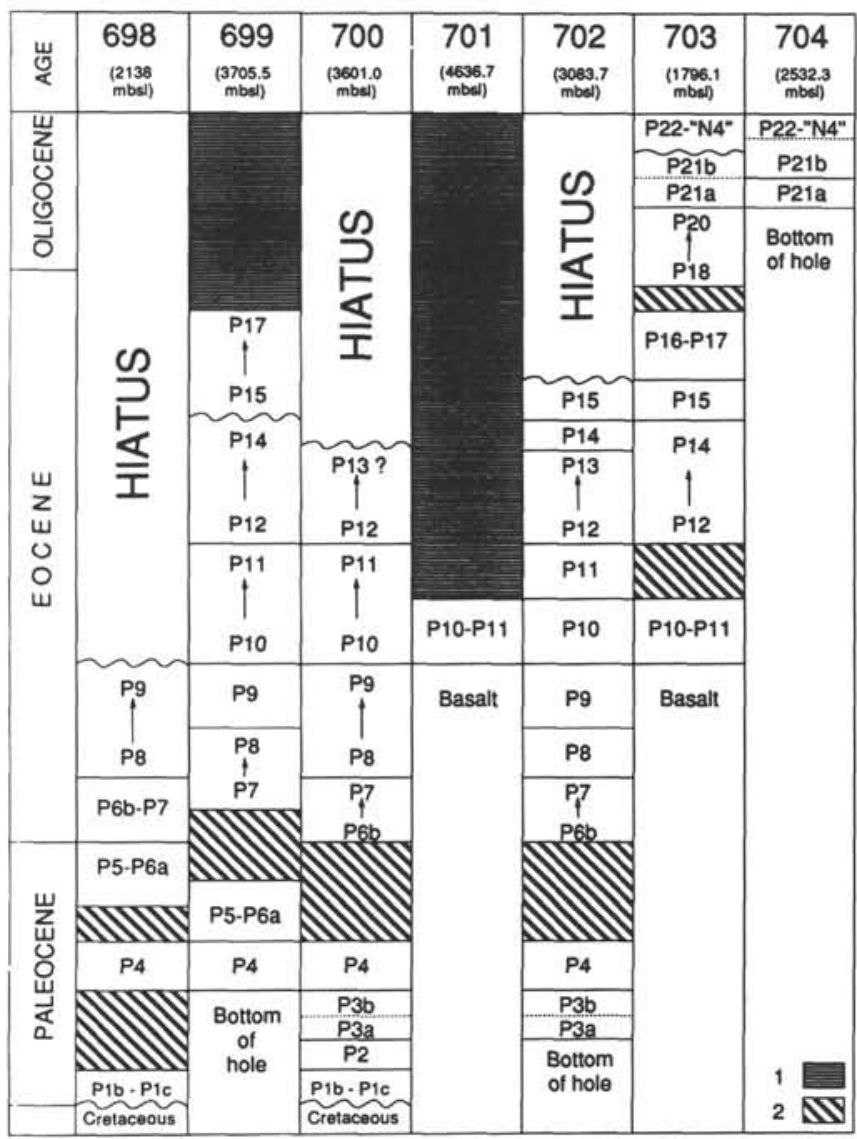

Figure 14. Composite scheme of Paleogene planktonic foraminiferal zones, Sites 698 through 704. Patterns: $1=$ siliceous biofacies; 2 = no recovery or no sampling. 
is associated with the appearance of the other new taxa "Morozovella" schachdagica, rare Morozovella abundocamerata (at the top), Acarinina mckannai, and Acarinina praepentacamerata. Low-spired subbotinids, the chiloguembelinids, Subbotina pseudobulloides, and Tenuitella reissi still make up the bulk of the assemblage. Rare "Morozovella" uncinata is still present at the base of the zone.

\section{Zone P3b}

The assemblages attributed to this subzone, from Sites 700 and 702 , are similar to those from the previous zone except that species diversity increases with the appearance of the index species, Morozovella pusilla, and Morozovella simulatilis, "Morozovella" tadjikistanensis djanensis, Acarinina nitida, Acarinata acarinata, and Planorotalites ehrenbergi, all of which are generally rare except for the last taxon. The bulk of the assemblages is still composed of the subbotinids, the chiloguembelinids (also $>150 \mu \mathrm{m}$ ) " $S$." pseudobulloides, and much rarer $T$. reissi and Planorotalites compressus. When muricate forms, such as the acarininids and morozovellids, become much rarer, assemblages are dominated by the lowspired subbotinids or by A. mckannai. The large morozovellid lineage is represented by only $M$. abundocamerata.

\section{Zone P4}

The lower boundary of this zone, recorded in all four western sites $(698,699,700$, and 702$)$, is marked by the appearance of a few Planorotalites pseudomenardii. This index species, however, is recorded only at the base of the zone, whereas $P$. compressus is the only planorotalitid that occurs, although discontinuously, in the upper layers of the zone. " $S$." pseudobulloides, already rare at the base of the zone, became extinct in the lower part of it.

Significant fluctuations in abundance of various taxa from layer to layer are first observed in Zone P4. The alternating faunas are: (1) Acarinina mckannai frequently associated with Acarinina subsphaerica, "Acarinina" aquiensis, "Acarinina" chascanona, "Morozovella" tadjikistanensis, and " $M$." tadjikistanensis djanensis; (2) the low-spired subbotinids including $S$. triloculinoides, $S$. triangularis, Subbotina eocaenica, and Subbotina patagonica; and (3) the true acarininids ( $A$. nitida, A. acarinata, and A. velascoensis). Assemblages also contain, but never in abundance, A. praepentacamerata, $T$. reissi, the chiloguembelinids mainly of small size $(<150 \mu \mathrm{m})$, "Morozovella" convexa, and, finally, a possible new species of Globorotaloides, identified here as Globorotaloides sp. 1, which appears in the middle to upper part of Zone P4 in the small fraction $(<150 \mu \mathrm{m})$. Representatives of the large morozovellids are absent.

\section{Zones P5-6a}

The P5-6a zonal interval was recovered at Sites 698, 699, and 702 .

The absence of Planorotalites pseudomenardii through most of Zone P4, however, prevented identification of the P4/5 zonal boundary according to the standard definition. Consequently, the beginning of Zone P5 was tentatively placed above the extinction level of Subbotina triloculinoides, which is known to disappear close to the top of Zone P4 elsewhere. This is in agreement with the calcareous nannofossil data.

The youngest assemblages attributed to the Paleocene contain species of round-chambered acarininids inherited from the previous zones, except for $A$. subsphaerica, which is missing. Common species are " $M$." tadjikistanensis djanensis, which became extinct at the top of this interval; " $M$." convexa and other biconvex morozovellids; the low-spired subbotinids, mainly $S$. triangularis and $S$. eocaenica-S, pat- agonica; Globorotaloides sp. 1; common chiloguembelinids, including large-sized forms only at Site 698; and $T$. reissi; among others.

Important events in this interval are (1) the reappearance of Planorotalites represented by large-sized $P$. planoconicus, $P$. australiformis, and $P$. chapmani (sensu Berggren et al., 1967); (2) the FO of Zeauvigerina sp. at Site 698 among the biserial heterohelicids; and (3) the FO of sporadically common Acarinina interposita, Acarinina rotundimarginata, Acarinina rugosoaculeata, and Acarina gravelli. Large morozovellids, including Morozovella velascoensis, are missing. No layers show dominance of single groups.

\section{Early Eocene}

\section{Zones P6b-7}

This interval is recorded at Sites 698, 700, and 702.

The base of Zone P6b, equated to the Paleocene/Eocene boundary, is placed according to calcareous nannofossil data. In terms of planktonic foraminifers, this boundary seems to be marked by the FO of Planorotalites pseudoscitulus associated with an overall increase in abundance of all planorotalitids. Rare, small-sized Pseudohastigerina wilcoxensis occurs slightly higher, associated with Morozovella wilcoxensis.

Besides the abundant large and small-sized planorotalitids, in this interval planktonic foraminiferal assemblages are characterized by abundant Acarinina acarinata, $A$. nitida, $A$. esnaensis, and A. soldadoensis particularly in the fine fraction $(<150 \mu \mathrm{m})$, by large-sized Chiloguembelina midwayensis, by common "A." aquiensis and " $A$." chascanona, and by " $M$." convexa. "A." mckannai is the only large-sized, roundchambered acarininids present, but it decreases drastically in abundance. A few Globorotaloides sp. 1 and Globorotaloides sp. (Pl. 1, Figs. 13-15) occur also in the fraction $>150 \mu \mathrm{m}$.

Peculiar to this interval is the occurrence of a few large morozovellids, represented by the species Morozovella marginodentata, Morozovella subbotinae, and very rare Morozovella gracilis and Morozovella aequa. Low-spired subbotinids, enriched by the appearance of Subbotina eocaenica irregularis and Subbotina pseudoeocaena may be more abundant in some levels, but they never are so dominant as in some horizons of Zone P4. "Globorotalia" praecentralis occurs in some abundance in a single horizon, then disappears.

\section{Zone P8}

The lower boundary of this zone is placed at the level of the FO of Acarinina pentacamerata, which is mainly confined to the lower part of the zone and occurs only sporadically in any abundance. This zone, represented in all the western drill sites, is characterized by a major change in planktonic foraminiferal assemblages, which become dominated by Acarinina primitiva and its overgrown morphotype, attributed to Muricoglobigerina senni by Blow (1979). At the beginning of this acme, several new species appear in almost all genera or groups, resulting in a large increase in specific diversity. In particular, there are the appearances of Acarinina pseudotopilensis, A. triplex, and later A. praetopilensis among the subquadrate acarininids; of Morozovella lensiformis, $M$. dolabrata, and very rare Morozovella aragonensis along with $M$. subbotinae among the large morozovellids; of Subbotina inaequispira and $S$. pseudoeocaena compacta associated with the always common $S$. eocaenica-S. patagonica and $S$. pseudoeocaena irregularis among the low-spired subbotinids; of Globorotaloides turgida and Globorotaloides aff. suteri along with common, typically large-sized Globorotaloides sp. 1 among the globorotaloids; of the first representatives of the 
high-spired subbotinids, Subbotina eocaena, Subbotina corpulenta, Subbotina lozanoi, and very rare Subbotina higginsi; and of common "Globigerinatheka," very rare Pseudohastigerina micra, Acarinina bullbrooki, and small-sized "Morozovella" broedermanni, among others. The small acarininids are still very common in the fine fraction $(<150 \mu \mathrm{m})$ where they are associated with some Guembelitria. By contrast, the planorotalitids tend to decrease in both abundance and size upward and are more common in the $<150-\mu \mathrm{m}$ fraction. Moreover, the chiloguembelinids (always $<150 \mu \mathrm{m}$ in size), A. aquiensis, A. chascanona, $T$. reissi, and biconvex morozovellids all decrease in number.

\section{Zone P9}

This zone is also recorded in all western drill sites.

The lower boundary is placed at the FO of Morozovella crater, generally close to the FO of Pseudohastigerina danvillensis. Zone $\mathrm{P} 9$ seems to correspond to most of the range of $M$. crater, which, although never frequent, is continuously recorded throughout this interval (Pujol and Sigal, 1979). This correlation is corroborated by calcareous nannofossil (Crux, this volume) and paleomagnetic data (Hailwood and Clement, this volume).

The bulk of the P9 zonal assemblage is similar to that described from Zone P8 with all the acarininids more abundant in the fine fraction $(<150 \mu \mathrm{m})$ except for $A$. primitiva, which dominates the larger fraction $(>150 \mu \mathrm{m})$. The species first appearing in this interval are Catapsydrax taroubaensis and Cassigerinelloita amekiensis in the upper part. Biconvex morozovellids become more common in the lower to middle part of the zone, from where they decrease in number toward the top. Acarinina aquiensis and associated forms become rare and disappear at the top of the zone; the subbotinids, in general, as well as Acarinina pseudotopilensis and Acarinina praetopilensis, increase in abundance. Acarinina bullbrooki remains very rare.

\section{Middle Eocene}

\section{Zones P10-11}

This zonal interval is recorded at Sites 699, 700, and 702, whereas it is missing at Site 698 because of a large hiatus (see "Site Description" section).

The lower boundary of Zone P10 is placed on the basis of paleomagnetic data (Hailwood and Clement, this volume) and falls within Chron $22 \mathrm{~N}$ very close to the Chron 22N/21R boundary (Lowrie et al., 1982; Napoleone et al., 1983). Accordingly, Morozovella crater ranges up into the lower part of this interval, in contrast with that reported in the literature (Bolli et al., 1985), in which the disappearance of $M$. crater at midlatitude is equated to the early to middle Eocene boundary (=Zone P9/10 boundary).

The boundaries between Zones P10 and P11 and the overlying Zone P12 could not be documented on the basis of planktonic foraminiferal faunas or calcareous nannofossils, because both groups are missing the index species. They were placed through correlation of paleomagnetic data from Site 702 with other paleomagnetically calibrated sequences from the South Atlantic (Tauxe et al., 1983) and land sections (Lowrie et al., 1982; Napoleone et al., 1983). Accordingly, the P10/11 zonal boundary would fall between Chrons $21 \mathrm{~N}$ and 20R, whereas the P11/12 zonal boundary lies between Chrons $20 \mathrm{R}$ and $20 \mathrm{~N}$.

Planktonic foraminiferal assemblages attributed to Zone P10 are characterized by abundant $A$. primitiva, the lowspired subbotinids ( $S$. pseudoeocaena compacta, S. pseudoeocaena irregularis, and $S$. eocaenica-patagonica), some globorotaloids in the coarse fractions $(>150 \mu \mathrm{m})$ and by abundant acarininids, common pseudohastigerinids, common globorotaloids, and some Cassigerinelloita amekiensis and Guembelitria in the fine fractions $(<150 \mu \mathrm{m})$. Pseudohastigerina danvillensis increases in abundance in this zone. The planorotalitids are still common in the fine fraction $(<150 \mu \mathrm{m})$ up to the middle part of the zone, then abruptly decrease in abundance upward. Biconvex morozovellids, still common at the base of Zone P10, are absent in the upper part. The chiloguembelinids are rare throughout and the high-spired subbotinids are still a minor component of the faunas. Conversely, the upper part is characterized by the appearance of Globorotaloides oregonensis associated with a general increase in abundance and size of all globorotaloids.

Just above the boundary between Zones P10 and P11, defined according to paleomagnetic data, all planorotalitids disappear. Peculiar to Zone P11 is a general upward decrease in abundance of most of the species inherited from Zone P10, except for the still abundant $A$. primitiva, the globorotaloidids, and, to a lesser extent, the low-spired subbotinids.

The upper part of Zone P11 is characterized by the FO of Globigerinatheka index, Subbotina angiporoides, and Subbotina utilisindex. The FO of $G$. index is here used for marking the lower boundary of the late middle Eocene interval. The LO of Planorotalites and the younger FO of $G$. index seem to be recorded in the same order and are possibly coeval with the same events recorded by McGowran (1986) in South Australia.

\section{Zones P12-13}

This interval could be identified at Sites 700 and 702 .

As mentioned previously, the lower boundary of this interval was placed according to paleomagnetic data. In terms of planktonic foraminifers it occurs just above the FO of $G$. index. The upper boundary, according to paleomagnetic data from Site 702, is near the base of Chron $18 \mathrm{~N}$ (Fig. 15).

Planktonic foraminiferal assemblages, still dominated by Acarinina primitiva, are also characterized by the occurrence of Acarinina bullbrooki, A. decepta, the low-spired subbotinids ( $S$. pseudoeocaena irregularis, $S$. angiporoides, and $S$. utilisindex), rare high-spired subbotinids, the catapsydracids, Globorotaloides suteri, few G. oregonensis, Globigerinatheka index, and " $G$." senni in the coarse fractions and by the small round-chambered acarininids, the pseudohastigerinids, and common chiloguembelinids in the fine fractions $(<150 \mu \mathrm{m})$.

In the lower to middle part of this interval, attributed to Zone P12, the biconvex morozovellids reappear in some abundance before becoming extinct. Moreover, Subbotina eocaenica and Guembelitria disappear, whereas the subbotinids of the $\mathrm{S}$. angiporoides group increase in abundance upward. Rare Acarinina spinuloinflata are recorded in this interval.

In the upper part of this interval at Site $702,5 \mathrm{~m}$ below the Chron $18 \mathrm{R} / 18 \mathrm{~N}$ boundary, which is possibly still in Zone P12, two closely spaced horizons are characterized by the occurrence of common Catapsydrax africanus, allowing us to make a good correlation between Sites 700 and 702. Accordingly, the Eocene sequence at Site 700 is truncated at this level. At Site 702, where this interval is complete, its uppermost part, attributable to Zone P13, is characterized by a generalized decrease in abundance of most of the previously common taxa, such as the low-spired subbotinids, the small acarininids, the pseudohastigerinids, and Acarinina bullbrooki and, in contrast, by an increase in the abundance of Globigerinatheka index, the Subbotina angiporoides group, and Subbotina linaperta s. str., which appears in Zone P12. Acarinina primitiva is still dominant. 
The whole interval is also recorded at Sites 699 and 703; however, it cannot be distinguished from the overlying Zone P14 because of heavy dissolution at Site 699 and poor recovery at Site 703 (see "Site Description" section).

\section{Zone P14}

This zone is identified only at Site 702. Its lower boundary is defined by the previously mentioned paleomagnetic data. The upper boundary, however, is placed above the extinction level of Acarinina primitiva.

In this zone, planktonic foraminiferal assemblages gradually record the loss of the acarininids (represented only by $A$. primitiva and small round-chambered forms), the low-spired subbotinids, and Pseudohastigerina micra. "Globigerinatheka" senni and Pseudohastigerina danvillensis disappear at the base of the zone.

In general, planktonic foraminiferal assemblages are characterized by common globorotaloids, abundant Globigerinatheka index, common chiloguembelinids $(<150 \mu \mathrm{m})$, the catapsydracids, the $S$. angiporoides group, $S$. linaperta s. str., and $S$. eocaena (commonly with abortive chambers). The tenuitellids are still represented only by $T$. reissi.

At Site 699, because of the strong dissolution affecting the upper middle Eocene strata, planktonic faunas consist only of solution-resistant species, such as few $A$. primitiva, $G$. index, and some catapsydracids. At Site 703 , planktonic foraminiferal assemblages evolved similarly to those at Site 702 . However, poor recovery, especially in the upper part of the $A$. primitiva range, associated with some reworking, prevented precise placement of the lower boundary of Zone P14 at this site.

\section{Late Eocene}

\section{Zone P15}

The base of Zone P15, corresponding to the LO of Acarinina primitiva and associated with a marked decrease in abundance of the small round-chambered acarininids, is here equated to the beginning of the late Eocene. This zone is tentatively separated from the other late Eocene zones, although the index forms or other standard criteria for separating it are missing in the Leg 114 record. The identification of Zone P15 at Sites 702 and 703 is based on the occurrence of rare specimens belonging to the small acarininids, the occurrence of which above the major extinction level of this muricate group is confined to the lower part of Zone P15 in other areas (Poore, 1984; Boersma et al., 1987; Parisi et al., 1988; Premoli Silva and Boersma, 1988).

Planktonic foraminiferal assemblages contain very abundant $G$. index, common chiloguembelininds (also recorded sporadically in the $>150-\mu \mathrm{m}$ fraction), the globorotaloids, subbotinids with abortive chambers, catapsydracids, Subbotina linaperta s. str., the $S$. angiporoides group, and very rare Pseudohastigerina micra. A renewal among the tenuitellids was observed at the base of this zone with the appearance of Tenuitella clemenciae, Tenuitella gemma, and Tenuitella insolita (only at Site 703) replacing the older $T$. reissi and rare Praetenuitella. Among the small acarininids, just above the base of the zone, the FO of Acarinina aculeata (= Tenuitella aculeata Auct.) is observed, whereas the other forms successively disappear upward: first Acarinina collactea, followed by Acarinina medizzai, and finally A. rugosaculeata associated with $A$. aculeata. Except for the range of the latter taxon, the same succession of extinction events among the small acarininids was observed by McGowran (1986) in southern Australia.
Other events observed in Zone P15 are (1) a single horizon rich in Globigerinatheka luterbacheri along with the appearance of Paragloborotalia opima nana, which coincides with the LO of Subbotina linaperta s. str., and of the pseudohastigerinids in both sites, and (2) the FO of "Globigerina" ampliapertura at Site 702.

\section{Zones P16-17}

This interval, recorded only at Site 703, contains planktonic foraminiferal assemblages very similar to those described from the previous zone, except for the aforementioned disappearances. The assemblages are dominated by $G$. index up to Sample 114-703A-14H-CC, the only sample from that core. Moreover, the tenuiteliids increase in abundance, the chiloguembelinids, a common component of the finest fraction, consistently occur in the $>150-\mu \mathrm{m}$ fraction also, and the Subbotina angiporoides group is common.

Because of poor sampling from Core $114-703 \mathrm{~A}-14 \mathrm{H}$ as a result of drilling disturbances and the incomplete recovery of Core 114-703A-13H, the placement of the Eocene/Oligocene boundary, equated to the P17/18 zonal boundary, was inferred from paleomagnetic data. The identification of Chron $13 \mathrm{~N}$ at the top of Core 114-703A-13H suggests that the Eocene/ Oligocene boundary would fall lower in the missing portion of Core 114-703A-13H (Nocchi et al., 1986).

\section{Oligocene}

\section{Zones P18-20}

The placement of the Eocene/Oligocene boundary, and thus the base of Zone P18, within the missing portion of Core $114-703 \mathrm{~A}-13 \mathrm{H}$ is confirmed by the FO of Catapsydrax cf. dissimilis in the core catcher, followed closely upward by the LO of "Praetenuitella" insolita, an event considered characteristic of the latest Eocene/earliest Oligocene. The upper boundary of this interval is placed just above the LO of "Globigerina" ampliapertura, the nominal marker of Zone $\mathrm{P} 20$. The absence of the index species at Site 703 prevented further subdivision of this interval.

Planktonic foraminiferal assemblages in this interval are less diversified than in the lower or upper parts of the Paleogene. Moreover, in the upper part of the interval species diversity decreases to less than 10 species.

The diversified tenuitellids are further enriched by new species such as Tenuitella munda and Tenuitella cf. pseudoedita and by more abundant $T$. gemma. The chiloguembelinids are generally common in the $<150-\mu \mathrm{m}$ fraction and are rarer but constantly present in the coarse fractions. Catapsydrax dissimilis, Catapsydrax unicavus, the globorotaloids, and the Subbotina angiporoides group are among the most common components of the faunas. Moreover, in the lower part an acme of Globorotaloides sp. 1 and G. oregonensis was observed, in the middle to upper part of the interval "Globigerina" labiacrassata becomes common, and few Globigerina praebulloides occlusa first appear in the upper part. "Globigerina" ampliapertura is rare and occurs discontinuously throughout.

\section{Zone P21a}

This zone is recorded at Site 703 and it is apparently complete at Site 704. The lower boundary is well defined by the LO of G. ampliapertura at both Sites 703 and 704. At Site 703 the upper boundary is placed tentatively at the level of the chiloguembelinid disappearance, whereas at Site 704 it is uncertain because of poor recovery. 
Planktonic foraminiferal assemblages in this zone, together with most of the forms inherited from the previous interval, include Paragloborotalia opima opima and $P$. opima nana, common $G$. labiacrassata, and Globigerina praebulloides. In the lower part the Subbotina angiporoides group disappears. In the upper part several forms first appear: "Globigerina" anguliofficinalis, Tenuitellinata angustiumbilicata, and Cassigerinella chipolensis occur, each for a short interval with their ranges slightly overlappping.

\section{Zone P21b}

This zone is recorded at Sites 703 and 704 . However, at Site 703 it is not completely represented, whereas sediment thickness $(40 \mathrm{~m})$ at Site 704 seems to suggest that Zone P21b might be represented in its entirety. Uncertainty in estimating the completeness of this zone at Site 704 is due to the occurrence of faunas depauperated by dissolution in most of this interval, the presence of reworking, poor recovery, and the fact that index species are rarely represented in the assemblages. Calibration of bioevents to magnetostratigraphy in this interval is too poor to increase biostratigraphic resolution. Tentatively, the upper boundary is placed at the FO of large-sized Globigerina ciperoensis associated with " $G$." anguliofficinalis, which is followed shortly by the reappearance of Paragloborotalia pseudocontinuosa and by the FO of Globigerinita incrusta and "Globigerina" brazieri. All of these species are known to be normal components of the youngest Oligocene faunas.

Planktonic foraminiferal assemblages contain abundant Catapsydrax $(C$. dissimilis, $C$. dissimilis ciperoensis, and $C$. unicavus), "Globigerina" brazieri, tenuitellids larger than 150 $\mu \mathrm{m}$, Tenuitellinata angustiumbilicata, Globigerinita juvenilis, Globigerina praebulloides, $G$. praebulloides occlusa, $G$. ouachitaensis, "G." anguliofficinalis, and "G." euapertura. The zonal marker $P$. opima opima is present but never abundant.

\section{Zones P22-"N4"}

This interval is recorded from Sites 703 and 704 . The two zones included in this interval could not be separated because of the absence of the entire Globorotalia kugleri group, and thus of G. kugleri, the appearance of which marks the beginning of Zone N4. The upper boundary of this interval was placed just below the FO of Globoquadrina dehiscens and Globorotalia zealandica, which are considered Miocene index forms (Srinivasan and Kennett, 1983).

Planktonic foraminiferal assemblages consist of common catapsydracids, the globorotaloids, the tenuitellids (also $>150$ $\mu \mathrm{m})$, Paragloborotalia opima nana, P. pseudocontinuosa, "Globigerina" labiacrassata, "G.' brazieri, Globigerina praebulloides, G. praebulloides occlusa, G. ouachitaensis, "G." anguilofficinalis, G. ciperoensis, "G.," euapertura, "G." venezuelana, Globigerinita incrusta, Globoquadrina praedehiscens, "Globorotalia" obesa, Dentoglobigerina globularis, Globorotaloides praestainforthi, rare G. testarugosa, and G. variabilis in the upper part. Moreover, some dentoglobigerinids (D. galavisi and D. pseudovenezuelana) occur randomly. The few specimens of $P$. opima opima and rare chiloguembelinids that occur throughout this interval are interpreted as reworked. A single specimen of Globigerinoides was observed at Site 703 .

\section{Early Miocene}

\section{Zones N4-5}

This interval is recorded at Sites 703 and 704. The two zones cannot be separated because of the absence of Globorotalia kugleri. The lower boundary is placed at the FO of Globoquadrina dehiscens, whereas the upper boundary is placed according to the LO of Catapsydrax dissimilis. Plank- tonic foraminifer assemblages are very similar to those described from the previous interval. Besides the occurrence of G. dehiscens, some new species appeared: Globorotalia zealandica, "Globigerina" woodi, and "G." woodi connecta. No Globigerinoides were found.

Above the LO of Catapsydrax dissimilis, a very short interval at Site 703 is tentatively attributed to Zone N6. Planktonic foraminifers are rare and affected by dissolution.

\section{Tentative High-Latitudinal Zonal Scheme}

Several authors have proposed biostratigraphic zonal schemes based on planktonic foraminifers for the high latitudes, especially in the Southern Hemisphere. None of these schemes fully apply to the Subantarctic Convergence Zone, where, as shown in this chapter, Paleogene planktonic foraminiferal assemblages exhibit, at least sporadically, a combination of lowand high-latitude index faunas. This fact allows us, first, to apply the lower latitude standard zonation, as previously described, and, second, to calibrate at least some tie-points from highlatitude zonal schemes to the standard zonation.

In Figure 15, the main planktonic foraminiferal events used for constructing the zonal scheme proposed here are plotted against age, local zonation, standard zones, and paleomagnetic data.

Austral Paleogene zonations that apply best to the subantarctic region are those proposed by Jenkins (1985) for the early and early middle Eocene and by Ludbrook and Lindsay (1969) for younger levels. While one zone at the Eocene/ Oligocene boundary from Orr and Jenkins (1977) can be applied, the tentative zonation, shown in Figure 15, had to be completed with two new zones for the late Eocene and latest Oligocene, respectively. The former one, the Subbotina utilisindex Zone (interval zone), partially replaces the previous $S$. linaperta Zone. The latter taxon had to be dropped as an index form because paleomagnetic calibration proved its range was different in southern Australia from in the subantarctic region. The second new zone is named "Globigerina" brazori and spans the latest Oligocene-early Miocene. It corresponds to the interval between the LO of Paragloborotalia opima opima, associated locally with the FO of the nominal marker, and the FO of Globoquadrina dehiscens. The Globigerina euapertura Zone of Jenkins (1985) was restricted to the early late Oligocene, because the nominal taxon is absent in the upper part of the sequences recovered during Leg 114. Moreover, the LO of $P$. opima opima was considered a first-order event. Another biostratigraphically useful event is the LO of "Praetenuitella" insolita (= Globorotalia insolita in Orr and Jenkins, 1977). It was used for defining the upper boundary of the nominal zone, which was drawn as barely straddling the Eocene/ Oligocene boundary. We suspect that this partial range zone could represent only the earliest Oligocene. Poor recovery in this interval from Leg 114 sites prevents the use of the LO of Globigerinatheka index for marking the Eocene/Oligocene boundary as it does in the southwestern Pacific.

Finally, the standard zonation was easily applied to the Paleocene interval, because most of the key biostratigraphic events marking zonal boundaries are present in the Leg 114 sequences.

\section{CORRELATION}

\section{Intersite Correlation}

Several biostratigraphic events, based on first, last, or only occurrence of planktonic foraminiferal taxa, have been found to recur in the same stratigraphic order in the Paleogene sequences recovered during Leg 114 . The most reliable succession of events is that based on the combined records from 


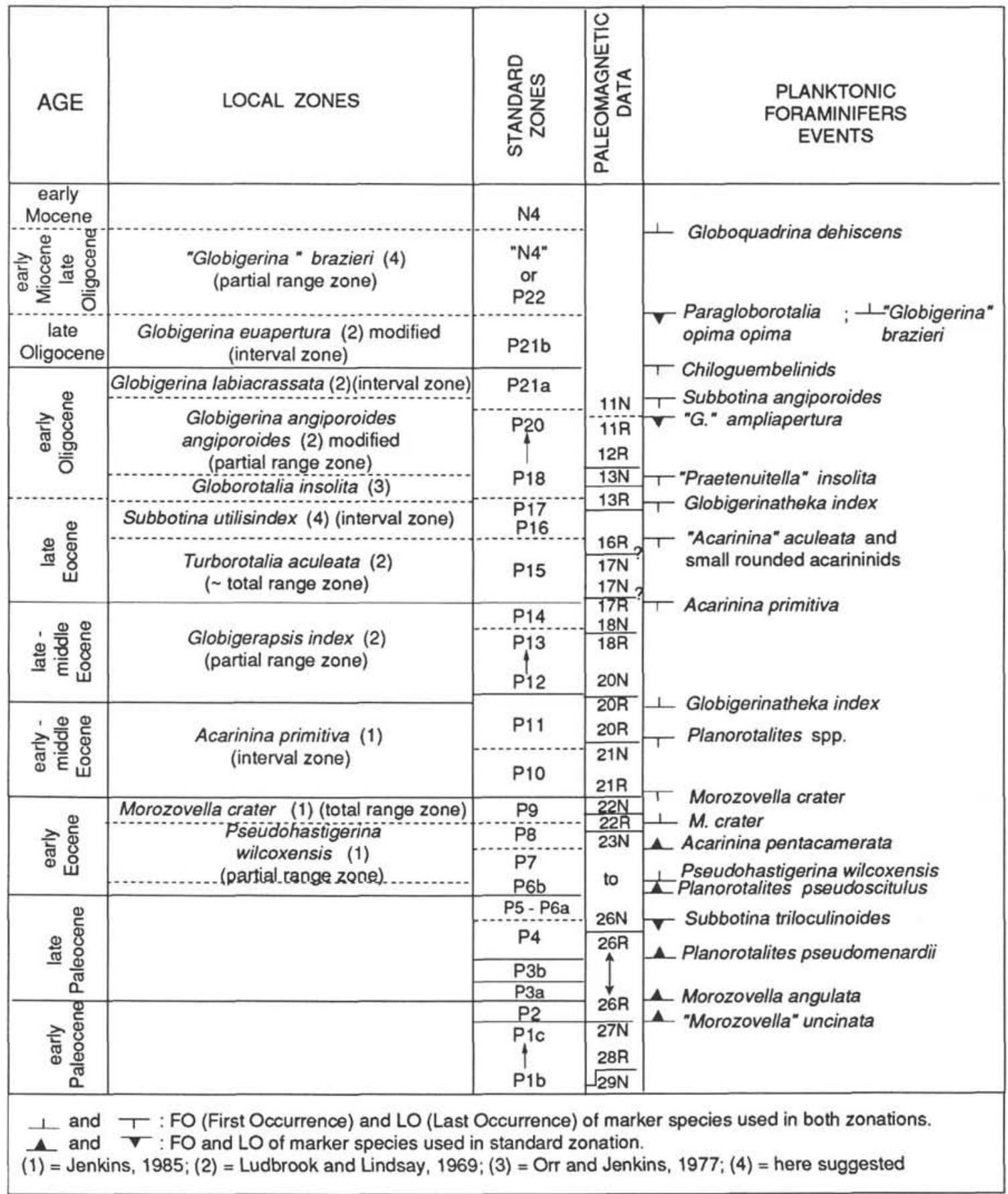

Figure 15. Planktonic foraminiferal biozonal scheme, Leg 114.

Sites 702 and 703 , which then provides a direct calibration to paleomagnetic stratigraphy. Such a succession of events was used as a framework to which all the other successions could be correlated. This allows us to demonstrate possible gaps, synchroneity and/or diachroneity of some events from site to site, and changes in sedimentary features. Correlatable, agediagnostic, or paleoenvironmentally significant events are plotted in Figure 16 against depth, standard planktonic biostratigraphy, and magnetostratigraphy.

Comparison among the various sites allows us to identify the following steps in the evolutionary history of the Atlantic subantarctic faunas:
1. Calcareous sedimentation characterized the opening of the Paleocene up through Zone P3a. Planktonic foraminiferal faunas evolved similarly to those from lower latitudes, except that some of the low-latitude index forms were less common in this area.

2. By the middle to early late Paleocene (Zones P3b-4), radiolarians appeared at the westernmost sites, whereas at Site 702 they were found to occur in small amounts only at the bottom of the hole. Planktonic foraminiferal assemblages started to evolve differently from their lower latitude counterparts. Large morozovellids temporarily disappeared, planorotalitids of the $P$. pseudomenardii group disappeared after a short acme of 
the nominate taxon early in Zone P4, and planktonic assemblages began exhibiting the dominance of one group vs. other groups, which alternate from layer to layer. The first representatives of the genus Globorotaloides appeared in this interval, increasing slightly in abundance upward.

3. In the middle of Zone P4, sediments are enriched in clay content. This thick interval at the westernmost sites thins eastward, but it is also present at Site 702 on the isolated Islas Orcadas Rise. Planktonic foraminifers in this layer are poorly preserved.

4. At the end of the Paleocene, carbonate sedimentation dominated. Radiolarians decreased in abundance, whereas planktonic foraminifers increased in diversity. The planorotalitids reappeared, but were represented by different species, mainly of smaller size than the $P$. pseudomenardii group.

5. From the beginning of the Eocene up to Zone P7, planktonic foraminiferal assemblages displayed the highest diversity and are the best preserved of the entire Paleogene sequence. They include some immigrant large morozovellid species, large-sized planorotalitids, and abundant and diversified acarininids, associated with more abundant globorotaloids, among others. Radiolarians are absent.

6. By early Eocene Zone P8, planktonic assemblages were dominated by a single species, Acarinina primitiva, which remained the most important species up to the middle to late Eocene boundary.

7. The early Eocene closes at all sites with a marker level of variable thickness, characterized by the occurrence in some abundance of Morozovella crater. Above this level, no more large morozovellids are recorded in the Atlantic subantarctic region.

8. With the beginning of the middle Eocene, dissolution of the planktonic foraminiferal assemblages begins at Site 699, whereas at nearby Site 700 , at almost the same water paleodepth, planktonic foraminifers are moderately well preserved. Calcareous sediments, recovered also at Site 701, the deepest site drilled at the foot of the Islas Orcadas Rise, were quickly replaced by predominantly siliceous sediments, which persisted through the remainder of the Paleogene. According to the calcareous nannofossil data, the sequence from Site 701 is affected by a hiatus spanning part of the middle Eocene. Poor planktonic foraminiferal assemblages were also recovered, but are mixed within a heterogeneous breccia at Site 703 on the Meteor Rise. At the other sites planktonic foraminifers are abundant and fairly well preserved.

9. By early middle Eocene Zone P11, planktonic foraminiferal faunas began to change: the globorotaloidids increased in abundance and size; the planorotalitids, already rare and of small size at the end of the previous interval, definitely disappeared; the Subbotina angiporoides group first occurred; and by the end of Zone P11 Globigerinatheka index appeared. Dissolution continued to heavily affect the planktonic faunas at Site 699 and, to a lesser degree, those at Site 700 . Radiolarians started to increase in abundance or were better preserved at Site 699 , and they were also recorded in minor amounts at Site 702 .

10. By the beginning of the late middle Eocene, sedimentary environments, which were relatively uniform during the previous intervals, became different at each site. At Site 699 sediments became dominantly siliceous and carbonate content decreased dramatically. A short hiatus at Site 699 encompasses the topmost part of the middle Eocene. At Site 700 carbonate content greatly decreased and planktonic assemblages, strongly affected by dissolution, consist only of a few solution-resistant species. Radiolarians further increased in abundance. The sequence is truncated at the level of the upper part of Zone P12-13? by a major hiatus. At Site 701 the predominantly siliceous sediments yield very few specimens of the solution-resistant species $A$. primitiva. By contrast, carbonate sedimentation continues at Site 702 , but planktonic foraminiferal assemblages, although rich in species, are slightly dissolved. Radiolarians are always present, but never abundant. At Site 703 carbonate sediments are dominant, but are disturbed by mass-flows and slumps. Close to the end of the middle Eocene, radiolarians also occurred on the eastern side of the South Atlantic.

11. During the late Eocene carbonate sedimentation occurred at three sites. At Site 699 dissolution is very strong and planktonic foraminifers are rare. Siliceous input rapidly increased there and predominated before the end of the Eocene. At Site 701 planktonic foraminifers are recorded only as fragments and the dominantly siliceous sediments became enriched in clay. Sites 702 and 703 still were sites of carbonate-rich sedimentation, which, however, at the former site is truncated by a major hiatus at the level of Zone P15 (or possibly the base of P16). Planktonic foraminiferal assemblages are dominated by Globigerinatheka index, which replaced $A$. primitiva as the dominant species after the middle Eocene. The tenuitellids became an important constituent of the faunas, chiloguembelinids are consistently found in the $>150-\mu \mathrm{m}$ fraction, and a pulse in abundance of Globigerinatheka luterbacheri allowed us to correlate the very distant Sites 702 and 703. Although planktonic foraminifers are only slightly affected by dissolution at Site 702 , dissolution was important, though variable, at Site 703, where radiolarians are also more abundant.

12. In the lower Oligocene up to Zone P20, very few planktonic foraminifers were found in the dominantly siliceous sediments of Site 699 . They are absent at Site 701, where siliceous sediments dominate. The only site where planktonic foraminifers of this age occur continuously is Site 703, where they are frequent but species diversity is low. An acme of Globorotaloides was observed and rare chiloguembelinids occur in the $>150-\mu \mathrm{m}$ fraction. Radiolarians are common.

13. In Zone P21a planktonic foraminifers are absent at Site 699 , where the interval is represented by siliceous sediments. At Site 701, a discrete hiatus, identified on the basis of siliceous organisms, includes this interval zone. Planktonic foraminiferal assemblages occur at Sites 703 and 704 associated with abundant radiolarians. Planktonic foraminiferal diversity increases, and the occurrence of the FO of "Globigerina" anguliofficinalis and short acmes of Cassigerinella chipolensis and Guembelitria stavensis, which partially overlap in the upper part of the zone, were recorded.

14. In Zone P21b radiolarians are common at Site 703, but few at Site 704. At Site 703 the upper part of Zone P21b is missing - or possibly all of the zone, as reworking makes identification of the P21a/21b boundary difficult-because of a short hiatus. Just before the gap, a remarkable increase in species diversity was noticed. At Site 704 , Zone P21b is apparently complete, but planktonic foraminifers are more dissolved, especially at the level where sedimentation was interrupted at Site 703.

15. The latest Oligocene is represented by siliceous sediments at Sites 699 and 701. A few species, including rare Cassigerinella chipolensis, are, however, recorded at Site 699 in the upper part of the Paleogene sequence. At Sites 703 and 704 calcareous sediments are well represented. Planktonic foraminiferal assemblages increase remarkably in diversity, and some warmer species are recorded, including "Globigerina" ciperoensis, "G." anguliofficinalis, Globoquadrina praedehiscens, a single Globigerinoides at Site 703, and a few dentoglobigerinids, among others. 

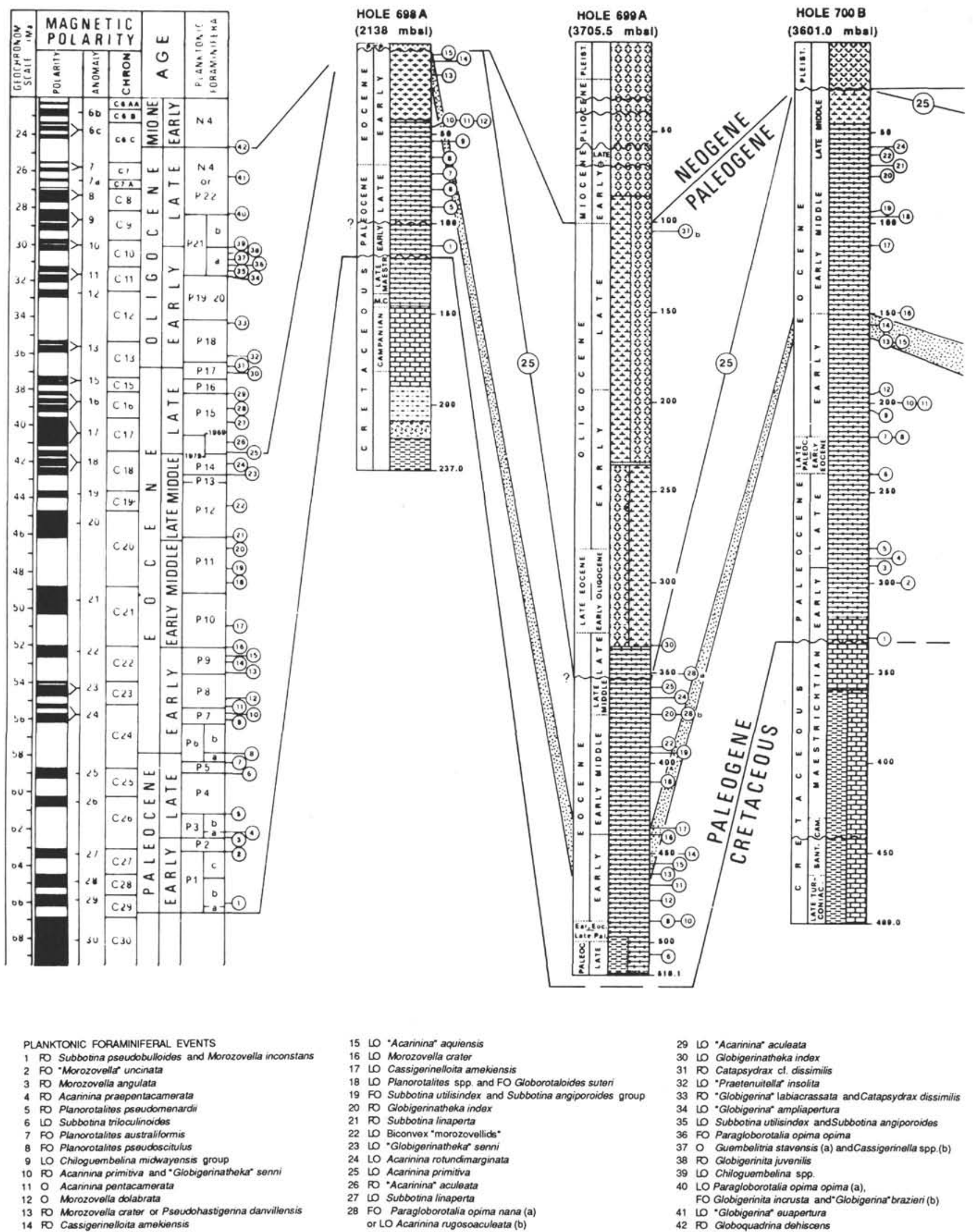

15 to 'Acarinina' aquiensis

16 L Morozovella crater

17 Lo Cassigerinelloita amekiensis

18 L Planorotalites spp. and FO Globorotaloides suteri

19 FO Subbotina utilisindex and Subbotina angiporoides group

20 Fo Globigerinatheka index

21 To Subbotina linaperta

22 L Biconvex "morozovellids"

23 L "Globigerinatheke' senni

24 LO Acarinina rotundimarginata

25 Lo Acarinina primitiva

26 Fo "Acarinina" aculeata

27 L Subbotina linaperta

28 FO Paragloborotalia opima nana (a)

\author{
29 10 "Acarinina' aculeata \\ 30 L 10 Globigerinatheka index \\ 31 RO Catapsydrax ct. dissimilis \\ 32 م 31 - Praetenuitells insolita \\ 33 TO "Glabigerina" labiacrassata andCatapsydrax dissimilis \\ 34 ம * - Globigerina ampliapertura \\ 35 ம Subbotina utlisindex and Subbotina angiporoides \\ 36 FO Paragioborotalia opima opima \\ 37 - Guembelitria stavensis (a) andCassigerinella spp.(b) \\ 38 TO Globigerinita juvenilis \\ 40 LO Paragloborotalia opima opima (a), \\ FO Globigerinita incrusta and "Globigerina" brazieri (b) \\ 41 เ "Globigerina' euapertura \\ 42 FO Globoquadrinatehiscens
}

Figure 16. Intersite correlation of Leg 114. M-C = Maestrichtian-Campanian; P-P = Pliocene-Pleistocene; eE-IP = early Eocene-late Paleocene. 
PLANKTONIC FORAMINIFERAL PALEOGENE BIOSTRATIGRAPHY

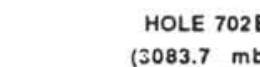

(3083.7 mbsl)

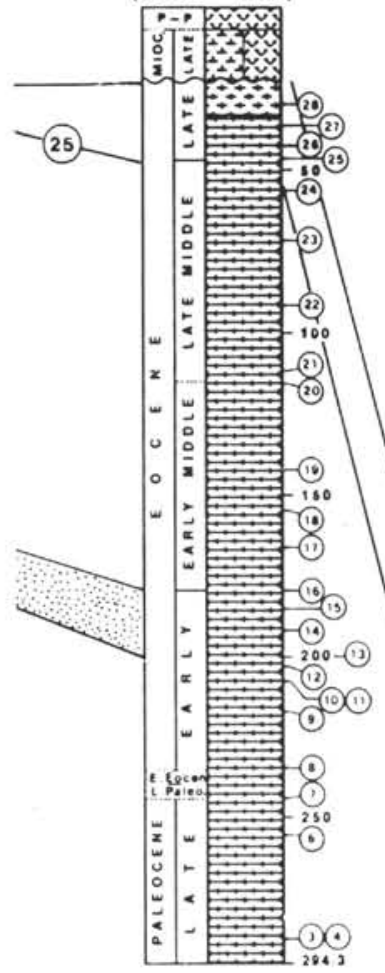

Morozovella crater Zone
HOLE 701C

(4636.7 mbsl)

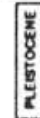

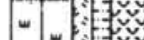

$x-25$

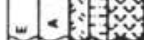

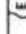

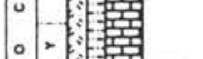

- 100

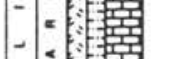

.

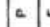
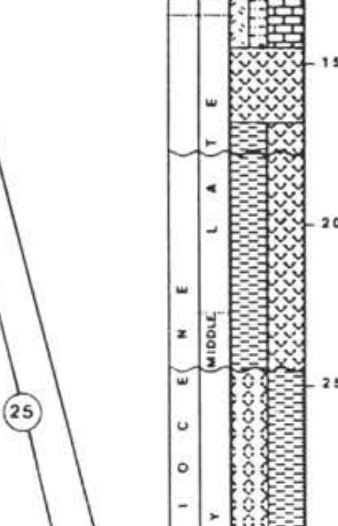

)

\section{$=$}

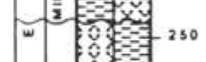

.

.

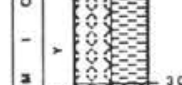

$=0.000$

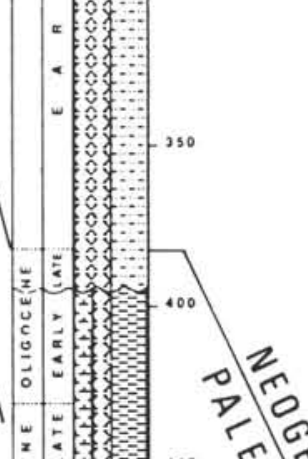

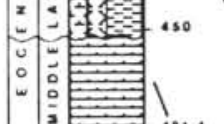

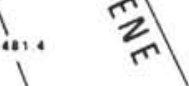

Figure 16 (continued). 
16. The Miocene N4-5 zonal interval is the last interval included in this study. Planktonic foraminiferal assemblages from both Sites 703 and 704 are once more poorly diversified and are dominated by the catapsydracids, a cooler, less solution-susceptible group, but Globoquadrina dehiscens and Globorotalia zealandica were also recorded. Rare radiolarians occur at Site 703.

\section{Correlation with the Other High-Latitude Sites Drilled in the South Atlantic}

The seven holes drilled during Leg 114 fill the central gap of the South Atlantic transect from the Falkland Plateau (Holes 327-330, DSDP Leg 36; Sites 511-514, DSDP Leg 71) in the western South Atlantic to the Cape Basin (Holes 360 and 361, DSDP Leg 40) in the southeastern Atlantic (see Krasheninnikov and Basov, 1986).

A comparison between the Paleogene planktonic foraminiferal record from Leg 114 and those from previous Legs 36 (Tjalsma, 1977), 71 (Krasheninnikov and Basov, 1983), and 40 (Toumarkine, 1978) allows us to describe spatially and temporally the evolution of the South Atlantic latitudinal belt between $51^{\circ} \mathrm{S}$ (western side) and $45^{\circ} \mathrm{S}$ (eastern side) during the Paleogene.

During most of the Paleocene siliceous sediments predominated on both sides of the South Atlantic. On the western side of the Mid-Atlantic Ridge the more external areas, such as the Maurice Ewing Bank, the Malvinas Outer Basin, and the Argentine Basin, received major clay and siliceous input, discontinuities due to erosional events were common, and sedimentary sequences were more condensed than in the central area (Sites 698-702). On the eastern side of the Mid-Atlantic Ridge, in the Cape Basin, zeolitic clay with some fish remains was recovered at Site 360 , located below the CCD. Paleocene sediments rich in carbonate were recorded on the Agulhas Plateau (Boersma and Premoli Silva, 1983) or much farther north at shallower depths than Site 360 . Specifically, at Site $524\left(29^{\circ} \mathrm{S}\right.$ modern latitude) the Paleocene sequence appears complete and planktonic foraminiferal assemblages exhibit a clearly warm character.

In the subantarctic region, the oldest Paleogene carbonaterich sediments were recovered at Site 329 (DSDP Leg 36), the shallowest site (1510 m water depth) drilled on the Falkland Plateau. These sediments yielded moderately rich planktonic foraminiferal assemblages of late Paleocene to early Eocene age that are very similar to those recovered from the western sites of Leg 114. At sites from both legs, late Paleocene large morozovellids are lacking and assemblages are dominated by the low-spired subbotinids, rounded-chambered large acarininids, the planorotalitids, rare "Morozovella" convexa, and Chiloguembelina wilcoxensis. The same species together with rare Morozovella subbotinae and $M$. aequa testify that the P6b-7 zonal interval recorded at Sites 698, 700, and 702 is at least partially represented also at Site 329 .

Although early Eocene age sediments are very poor in carbonate on the Falkland Plateau and in the Cape Basin, planktonic foraminifers are strongly dissolved in late early Eocene Zone P9, as indicated by the co-occurrence of Morozovella aragonensis and Morozovella crater $(=M$. aragonensis caucasica in Tjalsma, 1977; Toumarkine, 1978) associated with $A$. primitiva and " $G$." senni in both areas at Sites 327 and 361 , respectively.

In the western South Atlantic, middle Eocene sediments (about $90 \mathrm{~m}$ thick) containing planktonic foraminifers were recovered only from a shallower location (Site 512, $1846 \mathrm{~m}$ water depth) at the eastern margin of the Maurice Ewing Bank. At this site planktonic foraminiferal assemblages indicate that part of the interval corresponding to Zone P10 (the base is missing) and the entire Zone P11 up to possibly Zone P13, which are recorded in the sites here studied, are also present. The species recorded are Acarinina primitiva, $\operatorname{rare} A$. pseudotopilensis and A. bullbrooki, Globorotaloides suteri, Chiloguembelina cubensis, Subbotina angiporoides, $S$. utilisindex $(=S$. linaperta in Krasheninnikov and Basov, 1983), Pseudohastigerina micra, and Globigerinatheka index higher in the sequence. The well-preserved specimens illustrated by Krasheninnikov and Basov (1983) as Globigerina boweri and Globigerina frontosa are common in our material, but are considered to belong to the genus Subbotina, based on their wall structure. A single specimen of Hantkenina was also found at Site 512 , confirming that this taxon is mainly absent at high latitudes, independent of dissolution.

In the eastern Atlantic, at Site 361 (4549 m water depth) dissolution is still strong and results in a discontinuous planktonic record. Although planktonic foraminiferal assemblages are dominated by solution-resistant species, they contain some warmer taxa, such as Acarinina bullbrooki, Morozovella spinulosa, and representatives of the Turborotalia cerroazulensis lineage, which except for the former species were not recorded at the subantarctic sites. The middle Eocene record is more continuous at Site 360 and the warmer species recorded are more abundant in the assemblages than at Site 361. Beside those mentioned from Site 361, there are common and diversified Globigerinatheka, common Acarinina bullbrooki and A. spinuloinflata, Turborotalia pomeroli, and a few Hantkenina.

The major difference between planktonic foraminiferal assemblages from the Cape Basin and those from subantarctic sites is that the middle Eocene assemblages from the Cape Basin exhibit a much warmer character that makes them comparable to those from the Rio Grande Rise-Walvis Ridge region. Moreover, in the eastern Atlantic $S$. angiporoides and Globorotaloides occur later in the late Eocene and the genus Globigerinatheka exhibits higher species diversity.

Within the upper Eocene calcareous sediments are poorly represented on the Maurice Ewing Bank. At Site 511 planktonic foraminiferal assemblages are similar to those from the subantarctic transect except for the occurrence of Globoquadrina tripartita and lower species diversity at Site 511, where sediments consist of diatom-nannofossil oozes.

At Site 360 in the eastern Atlantic, late Eocene assemblages contain several species in common with those recorded from Sites 702 and 703 , such as $S$. linaperta, $S$. eocaena, $S$. angiporoides, G. index, T. gemma, Globorotaloides suteri, and Globigerinatheka luterbacheri. The latter species, however, is much more abundant and continuously present, "Globigerina" brevis occurs continuously in the upper part, and Turborotalia pomeroli and Hantkenina are present, whereas they have never been found in the subantarctic South Atlantic. At Site 361, late Eocene assemblages are recorded only in a very short interval between dissolved facies. Although they occur mixed together with some middle Eocene faunas, they contain some Globoquadrina tripartita and Dentoglobigerina galavisi in addition to $S$. angiporoides, few catapsydracids, and "G." brevis. Again, the late Eocene assemblages have a warmer character in comparison with the subantarctic sites.

In the western South Atlantic, Oligocene sediments containing planktonic foraminifers were recovered at Sites 329 and 511 on Maurice Ewing Bank and on the Falkland Plateau, respectively, at depths shallower than at Site 699, and at Site 513 (4373 $\mathrm{m}$ water depth) on the lower flank of the MidAtlantic Ridge in the southeastern Argentine Basin, at approximately at the same latitude as Site 703. At each site planktonic foraminifers occur mainly in the lower Oligocene. In 
fact, the late Oligocene/early Miocene age sediments grade upward from nannofossil diatomaceous ooze or nannofossil ooze/chalk to diatom ooze. The assemblages from all these sites are similar to the lower diversity faunas found in the lower Oligocene at Site 703, including S. angiporoides, $S$. utilisindex, Globorotaloides suteri, Chiloguembelina cubensis, Catapsydrax unicavus, C. dissimilis, "Globigerina" labiacrassata, Tenuitella munda, and T. gemma. However, in the lower Oligocene at Site 511 are forms such as Globigerina praebulloides, G. senilis, G. ouachitaensis, and T. angustiumbilicata, which occur later in the Oligocene (Zone P21) in our material, and "Globigerina" prasaepis, which is absent at the subantarctic sites. At Site 329, the shallowest drilled along the Falkland Plateau-Cape Basin transect, the occurrence of Paragloborotalia opima nana, Globigerina praebulloides, "Globigerina" woodi, and "G." brazieri above the LO of $S$. angiporoides suggests some similarity among this assemblage and the assemblages from Zone P21 and in the Zone P22"N4" interval at Site 703.

Considering all the holes drilled during Legs 36, 71, and 114 west of the Mid-Atlantic Ridge, the planktonic foraminiferal record is confined to the early Oligocene time both on the plateau and in the basinal area north of Site 701. After that time planktonic foraminifers were almost totally absent from the sediments, indicating that the strong decrease of planktonic foraminiferal abundance by the late Oligocene-early Miocene may be related either to a climatic exclusion (cooling) or to an increase in dissolution at depth. On the whole, west of the Central Atlantic area studied here, Paleogene sediments yielding low-diversity planktonic foraminiferal faunas are patchy and discontinuous.

East of the Mid-Atlantic Ridge, the Oligocene to early Miocene stratigraphic interval from Sites 703 and 704 can be correlated with that at Site 360 in the Cape Basin. Within the lower Oligocene the planktonic faunas are similar except for the absence of the globoquadrinids, Subbotina brevis, "Globigerina" euapertura, Paragloborotalia opima nana, Turborotalia increbescens, and Globorotaloides testarugosa in the subantarctic South Atlantic. In Zone P21 "Globigerina" euapertura, Paragloborotalia opima opima, P. opima nana, $P$. pseudocontinuosa, and Globigerina praebulloides were recorded at both Sites 703 and 360 . Moreover, above the chiloguembelinid extinction level, some events or occurrences are similar, such as the FO of Globigerinita juvenilis, "Globigerina" ciperoensis, and Tenuitellinata angustiumbilicata. At Site 360 Cassigerinella chipolensis also has a short range in Zone P21, but that occurs above the chiloguembelinid extinction instead of below it, as at Sites 703 and 704. "Globigerina" angulisuturalis is missing at all the sites, although its predecessor "Globigerina" anguliofficinalis is present. Globoquadrina dehiscens appears earlier at Site 360 than at Sites 703 and 704 , where it was recorded already in association with Globorotalia zealandica, a Miocene marker species. Sites 703 and 360 have several species in common in the lower Miocene, such as Catapsydrax dissimilis, "Globigerina" woodi and "G." woodi connecta, Globoquadrina dehiscens, Paragloborotalia pseudocontinuousa, and Globorotalia zealandica, typical species restricted to cool austral waters (Jenkins, $1978 \mathrm{~b})$. The genus Globigerinoides, however, is represented by a single specimen, but Globorotalia kugleri is absent at the Meteor Rise sites. Once more, the Oligocene assemblages, although very, similar in the areas of the Meteor Rise and the Cape Basin, exhibit a much warmer character in the Cape Basin than on Meteor Rise. This difference becomes more pronounced later in the Miocene. South of the area here investigated, Paleogene sequences were penetrated during Leg 113 in the Weddell Sea (Barker, Kennett, et al., 1988).
Paleocene and Eocene pelagic calcareous oozes/chalks, yielding abundant and well-preserved planktonic foraminifers, were recovered at Sites 689 and 690 on the Maud Rise, an aseismic ridge at $64^{\circ}$ and $65^{\circ} \mathrm{S}$ latitude, in water depths of 2080 and $2900 \mathrm{~m}$, respectively. A preliminary comparison between Paleogene planktonic foraminiferal faunas recovered from Legs 113 and 114 indicates that the assemblages are very similar and display a similar evolution in the early Paleocene, confirming the cosmopolitan character of planktonic foraminifers at that time (Boersma and Premoli Silva, 1983). By Zone P3 time, the planktonic assemblages from the two areas started to differentiate. Zone P3 seems to be missing on the Maud Rise. In Zone P4, identified here on the basis of calcareous nannofossil content (Barker, Kennett, et al., 1988), the Maud Rise assemblages are rich in round-chambered acarininids associated with "Morozovella" convexa and " M." djanensis, but Planorotalites pseudomenardii is apparently missing. Zones P5-6a, also recalibrated via calcareous nannofossils, are characterized by large planorotalitids (not $P$. pseudomenardii, but $P$. pseudoscitulus) and round-chambered acarininids as at the subantarctic sites, and the early Eocene Zone P6b-7 Maud Rise assemblages are devoid of large morozovellids. Large planorotalitids are common and the FO of Pseudohastigerina wilcoxensis occurs slightly higher than the Paleocene/Eocene boundary, according to calcareous nannofossils, as at Site 698 . The FO of Acarinina pentacamerata appears to be coeval with that from the subantarctic sites and should mark the base of Zone P8, but planktonic foraminifers from Site 690 did not register an increase in abundance of Acarina primitiva $(=A$. coalingensis Auct.). The absence of Morozovella crater in the late early Eocene age section at the Maud Rise sites prevents us from correlating between the two areas for that time. The remaining Eocene sequence at Sites 689 and 690 seems to contain planktonic faunas similar to those recorded in the subantarctic region, although species diversity is, in general, lower than in the subantarctic South Atlantic. The LO of the acarininids and of Globigerinatheka index, used for placing the middle to late Eocene boundary and the Eocene/Oligocene boundary, respectively, seem to be coeval or very close in time to those from the subantarctic sites.

From the late Eocene through the Oligocene in the Weddell Basin, siliceous biogenic facies progressively replaced the carbonate facies. Consequently, planktonic foraminifers became much less important, and species diversity was low. This sedimentary and microfaunal development is analogous to that recorded from the sequences penetrated at the western sites on the Mid-Atlantic Ridge during Leg 114.

\section{CONCLUSIONS}

Comparison of the occurrence and composition of Paleogene planktonic foraminiferal assemblages from the southernmost latitudes and from the lower latitude paleobiogeographic and paleoceanographic reconstructions in the Atlantic Ocean (e.g., Haq et al., 1977; Kennett, 1978; Boersma and Premoli Silva, 1983; Krasheninnikov and Basov, 1986; Boersma et al., 1987; Barker, Kennett, et al., 1988; Boersma and Premoli Silva, 1989) enhances our knowledge of the climatic evolution of Atlantic water masses during the Paleogene.

The Paleocene opened with the occurrence of the cosmopolitan planktonic foraminiferal assemblages of Zone Palpha (=P. eugubinus Zone) as far south as the Antarctic Ocean, despite distinct latitudinal paleotemperature gradients. During the remainder of the early Paleocene planktonic foraminiferal assemblages at such high latitudes exhibited the same evolutionary patterns recorded at lower latitudes. For example, species diversity among planktonic foraminifers increased as 
it did at lower latitudes. Only the lower latitude tropical indices, such as the ancestral morozovellids, occur in lower percentages in these very high-latitude faunas than at lower latitudes. The beginning of provinciality in Zones P2 and P3a is marked by the absence or rarity of "Morozovella" uncinata and $M$. angulata in the Maud Rise faunas.

Zone P3b time is characterized by the occurrence of some radiolarians associated with poorly preserved planktonic foraminifers at subantarctic latitudes and is spanned by a short hiatus in the Antarctic region. These data suggest that the spurious temperature drop in Zone P3b, related to dissolution by Boersma and Premoli Silva (1983), is expressed in faunas and related to changes occurring around Antarctica.

Although during late Paleocene Zone P4 the overall diversity among planktonic foraminifers increased, differences among planktonic assemblages from the subantarctic to the antarctic regions become more pronounced than those from lower latitudes; large morozovellids, already rare in the previous zone, are missing while consistently present in Zone P4 elsewhere in the Atlantic. Planorotalites pseudomenardii occurs very shortly only at subantarctic latitudes. The lowspired subbotinids, round-chambered acarininids, and rare biconvex morozovellids begin to fluctuate in abundance from layer to layer in the higher latitudes. The first representatives of the genus Globorotaloides were recorded earlier at the subantarctic sites, whereas rare globorotaloidids occur at lower latitudes only by the late early Eocene (Fig. 17). The occurrence of the globorotaloids, cooler dwelling forms (Boersma and Premoli Silva, 1986), would suggest that a new cooler niche opened at that time in these southern high latitudes several million years before it developed in lowlatitude upwelling zones. A dissolution event in the middle of Zone P4 is evidenced by a clayey layer widespread in the subantarctic region, and radiolarians become common components of Zone P4 faunas.

In the latest Paleocene Zones P5-6b radiolarians become less abundant, whereas the biofacies are dominated by wellpreserved, abundant planktonic foraminifers. Although large morozovellids are still missing, the assemblages are rich in small biconvex morozovellids, round-chambered acarininids, and common planorotalitids and globorotaloids (Fig. 17). It is at this time that planktonic foraminifers first occurred at locations closer to the South American continent on the Falkland Plateau. The resemblance of the faunas in subantarctic and antarctic assemblages corroborates the idea of the extended influence of warm boundary currents at high latitudes near the end of the Paleocene (Boersma and Premoli Silva, 1983; Barker, Kennett, et al., 1988).

A warming trend during the early Eocene is confirmed by the immigration to the subantarctic region of some large morozovellids. This immigration of warm, low-latitude indices coincided with the warmest period of the entire Eocene (Savin, 1977; Boersma et al., 1987). Although large morozovellids apparently never reached the Antarctic Ocean, planktonic assemblages there are well-diversified and contain species similar to those in the subantarctic region. Warmer conditions continued through the remainder of the early Eocene up to Zone P9 in the southernmost regions, as indicated by the persistent occurrence of large morozovellids at least at subantarctic latitudes. Marked change in subantarctic faunal composition is evidenced by the dominance of Acarinina primitiva, a high-latitude marker species beginning by Zone P8. That this Acarinina-dominance event is not reported from the antarctic region (Barker, Kennett, et al., 1988) may be related to the fact that studies of the latter region are still preliminary.

Latest early Eocene Zone P9 is a time of a paleobiogeographic uniformity throughout the entire subantarctic region.
The high-latitude Morozovella crater Zone (mainly Zone P9) (Fig. 16) is recorded from the Falkland Plateau on the west to the Cape Basin on the east, an area where dissolution effects at last decreased at this time. The antarctic region is still inhabited by warm faunas, although lacking the large morozovellids as in previous times.

By the beginning of the middle Eocene, the previously uniform faunas become more heterogeneous. At intermediatedepth Site 699 in the East Georgia Basin planktonic foraminifers are dissolved, whereas in all other locations including the antarctic region, planktonic assemblages are in general well diversified and moderately preserved up to the base of Zone P11. Within Zone P11 planktonic foraminiferal assemblages register a major change. The planorotalitids are replaced by new groups, such as the Subbotina angiporoides. group, followed slightly later by Globigerinatheka index. The overall character of the planktonic foraminiferal faunas is still warm-temperate, as evidenced by the occurrence of several acarininids also in the antarctic region. Radiolarians became important at the East Georgia Basin sites where dissolution also increased, and they occur in small amounts at the shallower Site 702.

The warm-temperate character of the foraminiferal faunas, still well diversified, is maintained through the remainder of the middle Eocene. However, at the deeper sites dissolution drastically increased and planktonic foraminifers were replaced by radiolarians as the major constituent of planktonic assemblages. By Zone P12 dissolution, although slight, affected also the shallower sites and hiatuses, even of short duration, affected the deepest Site 701, already enriched in siliceous organisms.

By the late Eocene, following the extinction of the acarininids, species diversity drastically decreased across the southernmost latitude sites; however, planktonic foraminiferal faunas were still temperate in character. Planktonic foraminiferal assemblages are dominated by $G$. index, but the warmer forms for that time, such as the Turborotalia cerroazulensis group or the dentoglobigerinids, are generally missing. This trend is interrupted by a warmer event in late Zone P15/earliest Zone P16, as evidenced by the occurrence of Globigerinatheka luterbacheri and of rare Globoquadrina tripartita. This event, however, seems confined only to the shallowest sites from the subantarctic region.

On the eastern side of the South Atlantic, after Zone P9, middle to late Eocene planktonic foraminiferal assemblages exhibit a much warmer character than their western counterparts. Consequently, the assemblages are more similar to those from the middle latitudes, even when affected by dissolution, as at the Cape Basin site. However, among the warmer water species, the turborotaliids are represented only by $T$. pomeroli, whereas the $T$. cerroazulensis lineage is missing.

Oligocene planktonic foraminifers occurred in the western South Atlantic mainly in the early Oligocene and at shallow depths. Where present, the assemblages consist only of cold, high-latitude indicators. On the contrary, in the eastern South Atlantic planktonic foraminifers are common or abundant, and a few subtropical species are present, as in the Eocene. The occurrence of rare Cassigerinella chipolensis, Guembelitria stavensis, "Globigerina" anguliofficinalis, and Paragloborotalia opima opima indicates a warmer interval in Zone $\mathrm{P} 21 \mathrm{a}$ also in the subantarctic region.

Of importance in the eastern Atlantic is the dissolution event within Zone P21b, which at some sites seems to be represented by an erosional event. Although the biostratigraphic calibration is not perfectly attained, it seems that a hiatus within siliceous sediments occurs at the same time also in the western South Atlantic at the deepest Hole 701. 


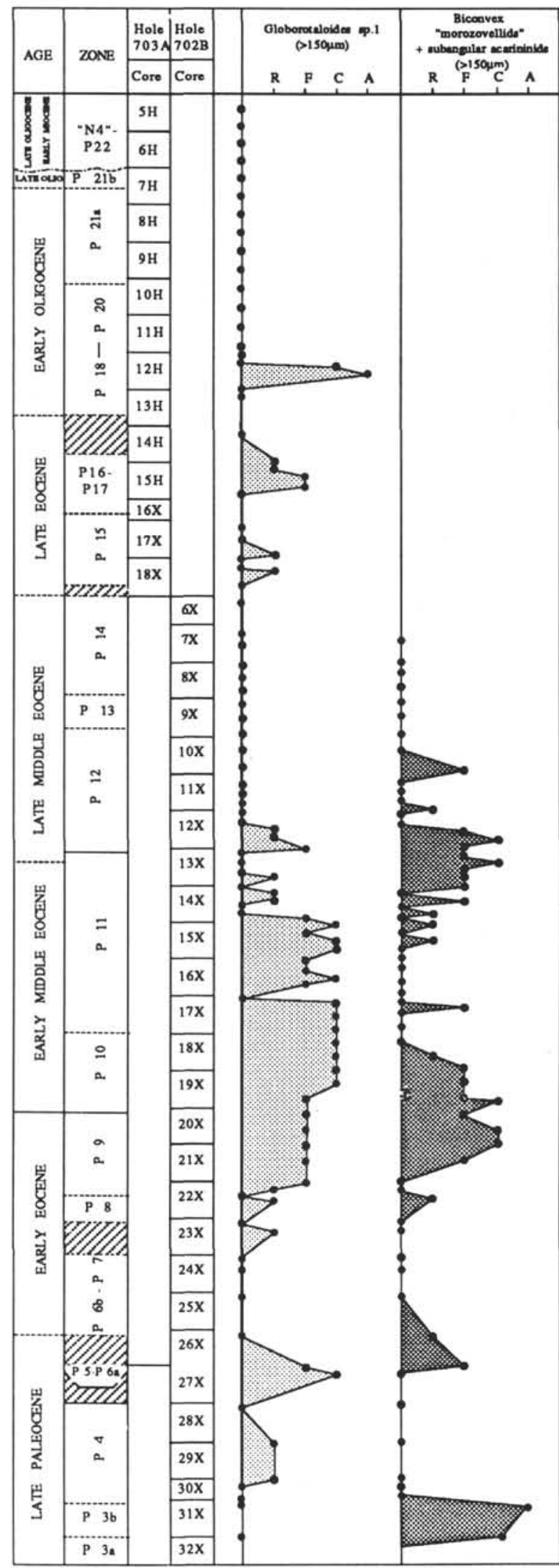

Figure 17. Relative abundance of Globorotaloides sp. 1 and biconvex "morozovellids" at Sites 702 and 703. 
Within the upper Oligocene Zones P22-"N4" planktonic foraminiferal faunas in the eastern Atlantic display evidence of a warming with a remarkable increase in species diversity and the occurrence of more abundant and diversified warmer indicators. Species composition again becomes more similar to those from lower latitudes. This warming event is registered also on the western side of the Mid-Atlantic Ridge by the occurrence of rare planktonic foraminifers, including few specimens of Cassigerinella, $P$. opima nana, and some globigerinids at shallow- and medium-depth sites. The preliminary data from the antarctic region do not allow us to state if the highest latitudes also experienced the immigration of planktonic foraminifers during this event.

The remarkable reverse of the late Oligocene warming trend in the early Miocene is evidenced by a drop in species diversity, the occurrence of species typical of the Pacific southern latitudes, and a new dissolution event.

\section{SPECIES LIST AND TAXONOMIC NOTES}

The generic and specific concepts and the species groups used by Boersma and Premoli Silva (1983), Boersma et al. (1987), and Premoli Silva and Boersma (1988) are retained herein, wherever possible. The comments and list of the species, which are in order of stratigraphic appearance in the distribution charts, are arranged in alphabetic order. The species figured in this paper are those rarely illustrated elsewhere or of stratigraphic interest. The identified species not here illustrated are referable to the indicated illustrations of other authors.

Acarinina acarinata Subbotina, 1953. (Pl. 1, Figs. 22, 23). Subbotina (1953), pl. XXII, figs. 4a, 4b, 4c.

"Acarinina" aculeata (Jenkins, 1971) (= Globorotalia (Turborotalia) aculeata Jenkins). (Pl. 4, Figs. 27, 28). Jenkins (1971), figs. 250-256.

Acarinina appressocamerata (Blow, 1979) (= Globorotalia (Acarinina) Blow). See Blow, 1979, pl. 144, figs. 2, 4-9.

"Acarinina" aquiensis (Loeblich and Tappan, 1957) (= Globigerina aquiensis Loeblich and Tappan). See Loeblich and Tappan (1957), pl. 56, figs. 4a-6c.

Acarinina bullbrooki (Bolli, 1957) (= Globorotalia bullbrooki Bolli). See Bolli (1957a), pl. 38, figs. 4-5.

"Acarinina" chascanona (Loeblich and Tappan, 1957) (= Globigerina chascanona Loeblich and Tappan). See Loeblich and Tappan (1957), pl. 49, figs. 4-5c.

Acarinina collactea (Finlay, 1939) (= Globorotalia collactea Finlay). See Jenkins (1965), figs. 1-27. In our specimens secondary apertures on the dorsal side are not visible.

Acarinina cuneicamerata (Blow, 1979) (= Globorotalia (Acarinina) cuneicamerata Blow). See Blow (1979), pl. 153, figs. $1-4$.

Acarinina decepta (Martin, 1943) (= Globigerina decepta Martin). See Martin (1943), pl. 7, figs. 2a-2c.

"Acarina" echinata (Bolli, 1957) (= Catapsydrax echinatus Bolli). See Bolli (1957a), pl. 37, figs. 2-5.

Acarina esnaensis (Le Roy, 1953) (= Globigerina esnaensis Le Roy). (Pl. 1, Figs. 24-26). Le Roy (1953), pl. 6, figs. 8-10.

Acarinina gravelli (Brönnimann, 1952) (= Globigerina gravelli

Brönnimann). See Brönnimann (1952), pl. 1, figs. 16-18.

Acarinina aff. hainesi (Samanta, 1970) (= Truncorotaloides hainesi Samanta). See Toumarkine and Luterbacher (1985), fig. $32(2-3)$.

Acarinina intermedia Subbotina, 1953. See Subbotina (1953), pl. XX, figs. 14-16.

Acarinina interposita Subbotina, 1953. See Subbotina (1953), pl. XXIII, figs. 7a, 7b, 7c.

Acarinina aff. libyaensis (El Khoudary, 1977) (= Truncorotaloides libyaensis El Khoudary). (PI. 2, Figs. 10-12).
Toumarkine and Luterbacher (1985), fig. 32 (4-6). This very rare form has six chambers with an imbricated arrangement in the last whorl similar to the holotype, but with a closer umbilicus and a more angular axial profile.

Acarinina matthewsae (Blow, 1979) $(=$ Globorotalia (Acarinina) matthewsae Blow). See Blow (1979), pl. 170, figs. 1-9.

Acarinina aff. mattseensis alticonica Fleisher, 1974. (PI. 3, Figs. 20-23) Fleisher (1974), pl. 2, figs. 1-5. In subantarctic material there are several specimens similar to Acarinina mattseensis alticonica but with fewer chambers in the final whorl and a shorter spire than Fleisher's species. Named here as A. aff. mattseensis alticonica, they appear in Zone P8 but have a longer range (from Zones P8 to P11) than Fleisher's species, which has been found only in samples of Zone P8 age. These forms may be related to the muricoglobigerinids.

Acarinina mckannai (White, 1928) (= Globigerina mckannai White). See Toumarkine and Luterbacher (1985), fig. 18 (3-6).

Acarinina medizzai (Toumarkine and Bolli, 1975). (Pl. 4, Fig. 23). Toumarkine and Bolli (1975), pl. 5, fig. 16; pl. 6, figs. $1,5,7,8$. This form seems closely related to Acarinina rugosoaculeata.

Acarinina nitida (Martin, 1943) (= Globigerina nitida Martin). (Pl. 1, Figs. 19-21). Martin (1943), pl. 7, fig. 1. We consider this species separate from $A$. acarinata because of its more subquadrate equatorial profile, less rounded axial periphery, more subrectangular chambers on the dorsal side of the last whorl, and more umbilical-extraumbilical aperture. Some forms suggest a relationship between $A$. nitida and Acarinina primitiva (Pl. 1, Figs. 4-6).

Acarinina pentacamerata Subbotina, 1953. See Subbotina (1953), pl. XXIV, figs. 1-6.

Acarinina pentacamerata acceleratoria Khalilov, 1956. See Khalilov (1956), pl. 5, figs. 7a-7c.

Acarinina pentacamerata acceleratoria Khalilov, 1956. See Khalilov (1956), pl. 5, figs. 6a-6c.

Acarinina planodorsalis Fleisher, 1974. See Fleisher (1974), pl. 2, figs. 6-9; pl. 3, figs. 1, 2.

Acarinina praepentacamerata (Shutskaya, 1956) (= Globorotalia praepentacamerata Shutskaya). See Luterbacher (1964), fig. 45.

Acarinina praetopilensis (Blow, 1979) $(=$ Globorotalia (Truncorotaloides) topilensis praetopilensis Blow). See Blow (1979), pl. 169, figs. 1-9. This species occurs in Zone P9 and is ancestral to A.topilensis, a characteristic form of the middle Eocene.

Acarinina primitiva (Finlay, 1939) (= Globoquadrina primitiva Finlay). (Pl. 3, Figs. 1-18). Jenkins (1971), pl. 18, figs. 555-561. In our material there are numerous forms tending to make more compact tests with a subquadrate equatorial periphery, thickening the wall, with a tight coiling mode and a deep subquadrate umbilical area. Most of these specimens have a final abortive chamber further restricting the umbilical area. Their relationship with typical $A$. primitiva is evidenced by the characteristic very steep apertural face of the last chambers and by the possession of a muricate wall.

Acarinina pseudotopilensis Subbotina 1953. See Subbotina (1953), pl. XXI figs. 8-9; pl. XXII, figs. 1-2.

Acarinina cf. punctocarinata Fleisher, 1974. See Fleisher (1974), pl. 3, figs. 4-8.

Acarinina cf. quadratoseptata Davidzon and Morozova, 1964. See Davidzon and Morozova (1964), pl. 2, figs. 1-3.

Acarinina rohri piparoensis (Brönnimann and Bermudez, 1953) (= Truncorotaloides rohri var. piparoensis Brönnimann and Bermudez). See Toumarkine and Luterbacher (1985), Fig. 32 (11). This is one of the few species with 
secondary sutural apertures on the spiral side that occurs in the studied area.

Acarinina rotundimarginata Subbotina, 1953. See Subbotina (1953), pl. XXV, figs. 1-3.

Acarinina rugosoaculeata Subbotina, 1953. See Subbotina (1953), pl. XXV, figs. 4-5.

Acarinina soldadoensis (Brönnimann, 1952) (= Globigerina soldadoensis Brönnimann). See Sigal (1974), pl. 6, figs. 1a-1c.

Acarinina soldadoensis angulosa (Bolli, 1957) (= Globigerina soldadoensis Brönnimann subsp. angulosa Bolli). See Bolli (1957c), pl. 16, figs. 4-6.

Acarinina spinuloinflata (Bandy, 1949) (= Globigerina spinuloinflata Bandy). See Cifelli (1972), figs. 2a-2c.

Acarinina spiralis (Bolli, 1957) (= Globigerina spiralis Bolli). See Bolli (1957a), pl. 16, figs. 13-18.

Acarinina subsphaerica (Subbotina, 1947) (= Globigerina subsphaerica Subbotina). See Ellis and Messina (1940), figs. 23-28; Blow (1979), pl. 93, fig. 6; pl. 91, figs. 4-6.

Acarinina topilensis (Cushman, 1925) (= Globigerina topilensis Cushman). See Toumarkine and Luterbacher (1985), Fig. 33 (1-7).

"Acarinina" trichotrocha (Loeblich and Tappan, 1957) (= Globorotalia trichotrocha Loeblich and Tappan). See Loeblich and Tappan (1957), pl. 50, figs. 5a-5c.

Acarinina triplex Subbotina, 1953. See Subbotina (1953), pl. XXIII, figs. 1-5.

Acarinina velascoensis (Cushman, 1925) (= Globigerina velascoensis Cushman). See Sigal (1974), pl. 6, figs. 7a-7c.

Acarinina whitei (Weiss, 1955) (= Globorotalia whitei Weiss). See Ellis and Messina (1940), figs. 1-3. This rare species has been found only in the upper Paleocene and is considered separate from $A$. rotundimarginata on the basis of its more angular axial periphery.

Cassigerinella chipolensis (Cushman and Ponton, 1932) (= Cassidulina chipolensis Cushman and Ponton). See Bolli and Saunders (1985), Fig. 16 (1-2).

Cassigerinelloita amekiensis Stolk, 1965. (PI. 4, Figs. 1, 2). Stolk (1965), pl. 1, fig. 1. In agreement with Stolk's suggestion, this species is probably related to Guembelitria, with which it is always associated in the Eocene, rather than to the genus Globigerinita as suggested by Blow (1979). In fact, the final apertures in Cassigerinelloita and Guembelitria are similar (Pl. 4, Fig. 3), and in both taxa no true umbilicus is present because the walls of the opposing chambers of each whorl join without leaving an umbilical cavity. The range of $G$. amekiensis is from uppermost Zone P9 to Zones P10-11, in agreement with the stratigraphic range reported by Stolk (1965) from southern Nigeria.

Catapsydrax africanus (Blow and Banner, 1962) (= Globigerinita africana Blow and Banner). See Blow and Banner (1962), pl. XV, figs. A-C.

Catapsydrax dissimilis (Cushman and Bermudez, 1937) (= Globigerina dissimilis Cushman and Bermudez). See Blow and Banner (1962), pl. XIV, fig. d.

Catapsydrax cf. dissimilis. The specimens here included are smaller in size, with a tighter coiling and less lobulate periphery, than the typical $C$. dissimilis; however, they possess a clear bulla with two infralaminal accessory apertures. Catapsydrax dissimilis is considered to appear in the lower Oligocene (Molina, 1979).

Catapsydrax dissimilis ciperoensis (Blow and Banner, 1962) (= Globigerinita dissimilis ciperoensis Blow and Banner). See Blow and Banner (1962), pl. XIV, figs. A-C.

Catapsydrax globiformis (Blow and Banner, 1962) (= Globigerinita globiformis Blow and Banner). See Blow and Banner (1962), pl. XIV, figs. S-U.
Catapsydrax taroubaensis (Brönnimann, 1952) (= Globigerina taroubaensis). See Bolli (1957c), pl. 15, figs. 1, 2.

Catapsydrax unicavus Bolli, Loeblich, and Tappan, 1957. See Bolli, Loeblich, and Tappan (1957), pl. 7, figs. 9a-9c. Only specimens very close to the holotype were included in $C$. unicavus. They become abundant and clearly identifiable only in the Oligocene.

Chiloguembelina cubensis (Palmer, 1934) (= Guembelina cubensis Palmer). See Palmer (1934), figs. 1-6.

Chiloguembelina midwayensis group Beckmann, 1957. See Beckmann (1957), pl. 21, figs. 1-3, 6.

Chiloguembelina wilcoxensis (Cushman and Ponton, 1932) (= Guembelina wilcoxensis Cushman and Ponton). See Beckmann (1957), pl. 21, figs. 10a, 10b, 12a-13.

Dentoglobigerina galavisi (Bermudez, 1961) (= Globigerina galavisi Bermudez). See Bermudez (1961), pl. 4, fig. 3.

Dentoglobigerina globularis (Roemer, 1838) (= Globigerina globularis Roemer). See Rögl (1985), fig. 4 (9-10).

Dentoglobigerina pseudovenezuelana (Blow and Banner, 1962) (= Globigerina yeguaensis pseudovenezuelana Blow and Banner).

See Blow and Banner (1962), pl. XI, figs. J-L, N, O.

"Globigerina" ampliapertura Bolli, 1957. See Bolli (1957b), pl. 22, figs. 5-6.

"Globigerina" anguliofficinalis Blow, 1969. (Pl. 5, Figs. 6-8). Blow (1969), pl. 11, figs. 1-5.

"Globigerina" brazieri (Jenkins, 1966) (= Globigerina brazieri Jenkins). (Pl. 5, Figs. 15-17). Jenkins (1985), p. 274, fig. $6(20 \mathrm{a}-20 \mathrm{c})$.

"Globigerina" ciperoensis Bolli, 1957. (PI. 5, Fig. 9). Bolli (1957b), pl. 22, figs. 10a-10b.

"Globigerina" connecta Jenkins, 1964. See Kennett and Srinivasan (1983), pl. 8, figs. 1-3.

"Globigerina" euapertura Jenkins, 1960. See Jenkins (1985), fig. 6 (18a-18c).

"Globigerina" labiacrassata Jenkins, 1966. (Pl. 5, Figs. 11, 12). See Jenkins (1985), Fig. 6 (19a-19c).

Globigerina officinalis Subbotina, 1953. See Subbotina (1953), pl. 11, figs. 1-7.

Globigerina ouachitaensis Howe and Wallace, 1932. See Blow and Banner (1962), pl. IX, figs. D, H-K.

Globigerina praebulloides Blow, 1959. See Blow and Banner (1962), pl. IX, figs. O-Q.

Globigerina praebulloides leroyi Blow and Banner, 1962. See Blow and Banner (1962), pl. IX, figs. R-T.

Globigerina praebulloides occlusa Blow and Banner, 1962. See Blow and Banner (1962), pl. IX, figs. U-W.

“Globigerina" pseudodruryi Brönnimann and Resig, 1971. See Brönnimann and Resig (1971), pl. 7, figs. 1, 2.

Globigerina senilis Bandy, 1949. See Blow and Banner (1962), pl. XI, figs. R-U.

"Globigerina" venezuelana Hedberg, 1937. See Bolli and Saunders (1985), Fig. 13 (20).

"Globigerina" woodi s. str. Jenkins, 1960. See Chapronière (1988), pls. 1, 2. In our material it is quite difficult to keep separated from "Globigerina" labiacrassata specimens with almost a trilobate test and a large final chamber illustrated by Chapronière as G. woodi. We consider " $G$." woodi to have a wider arched aperture and a thinner lip than " $G$."' labiacrassata.

Globigerinatheka index (Finlay, 1939) (= Globigerinoides index Finlay). (Pl. 4, Figs. 17-22). Toumarkine and Luterbacher (1985), fig. 38 (20-24).

Globigerinatheka luterbacheri Bolli, 1972. (Pl. 4, Fig. 29). Toumarkine and Luterbacher (1985), fig. 38 (1-13).

Globigerinatheka rubriformis (Subbotina, 1953) (= Globigerinoides rubriformis Subbotina). (Pl. 4, Fig. 30). Toumarkine and Luterbacher (1985), fig. 38 (18-19). 
"Globigerinatheka" senni (Beckmann, 1953) (= Sphaeroidinella senni Beckmann). (PI. 3, Fig. 19). Toumarkine (1978), pl. 10, figs. 10-14. In our material there are several forms similar to Globigerina senni as illustrated by Toumarkine (1978), which have some morphological analogy with the compacted and thickened forms of A. primitiva. They differ from the latter by their rounded and lobate equatorial peripheral margin and by the shape of the umbilical area, which is more elongated and apparently without umbilical muricae.

Globigerinatheka subconglobata (Shutskaya, 1958) (= Globigerinoides subconglobatus var. subconglobata Khalilov (ms.) in Shutskaya, 1958). See Toumarkine and Luterbacher (1985), fig. 40 (16-20).

Globigerinita incrusta Akers, 1955. (Pl. 5, Figs. 18-20). Akers (1955), pl. 65, figs. 2a-2d.

Globigerinita juvenilis (Bolli, 1957) (= Globigerina juvenilis Bolli). (Pl. 5, Figs. 3-5). Bolli (1957b), pl. 24, figs. 5, 6. In our material there are specimens without a bulla or with a bulla lacking sutural expansions; the spiral side can be more or less elevated with few high-spired forms tending to Globigerinita bradyi. The first occurrence is within Zone P21a.

Globoconusa daubjergensis (Brönnimann, 1953) (= Globigerina daubjergensis Brönnimann). See Sigal (1974), pl. 3, figs. 1a-1c. Globoquadrina dehiscens (Chapman, Parr, and Collins, 1934) (= Globorotalia dehiscens Chapman, Parr, and Collins). (Pl. 5, Figs. 21-23). Bolli and Saunders (1985), fig. 15 (4-7).

Globoquadrina dehiscens praedehiscens Blow and Banner, 1962. (Pl. 5, Figs. 24-26). Blow and Banner (1962), pl. 15, figs. $\mathrm{O}-\mathrm{S}$. This species has a short range and it appears after the LO of Paragloborotalia opima opima. Its stratigraphic distribution is late Oligocene/early Miocene.

"Globorotalia"' obesa Bolli, 1957. See Bolli (1957b), pl. 29, figs. $2 \mathrm{a}-3$.

"Globorotalia" praecentralis Blow, 1979. (Pl. 2, Figs. 20-25). Blow (1979), pl. 135, figs. 7-9; pl. 136, figs. 1-6.

"Globorotalia" aff. praecentralis Blow, 1979. (PI. 1, Figs. 16-18). This specimens shows numerous chambers in the last whorl and a characteristic concave-convex axial profile. The closest form is "Globorotalia" centralis.

Globorotalia scitula praescitula Blow, 1959. See Kennett and Srinivasan (1983), pl. 25, figs. 4-6.

Globorotalia zealandica Hornibrook, 1958. See Kennett and Srinivasan (1983), pl. 25, figs. 1-3.

Globorotaloides aff. carcoselleensis Toumarkine and Bolli, 1975. See Toumarkine and Luterbacher (1985), Fig. 41 (9-16).

Globorotaloides oregonensis (McKeel and Lipps, 1975) (= Subbotina oregonensis McKeel and Lipps). (PI. 6, Figs. 23-25). McKeel and Lipps (1975), pl. 4, figs. 3a-3c. This form is considered to belong to the genus Globorotaloides because of the association of an initial globorotaliform coiling mode with globigeriniform outer chambers and a coarsely honeycomb wall structure. It differs from Globorotaloides sp. 1 in having only three chambers in the last whorl. Its range is discontinuous; it first occurs in lower middle Eocene Zone P10 and ranges through Zone P11, and then it reappears in the lower Oligocene.

Globorotaloides praestainforthi (Blow, 1969) (= Globigerinita stainforthi praestainforthi Blow). See Blow (1969), pl. 25 , figs. 3-5.

Globorotaloides suteri Bolli, 1957. See Bolli (1957b), pl. 27, figs. 9-13. Herein this form appears much earlier than in Trinidad (probably in Zones P10-11).

Globorotaloides aff. suteri Bolli, 1957. (Pl. 4, Figs. 4, 5). This form is common in the size fraction $<150 \mu \mathrm{m}$ from late Paleocene throughout middle Eocene. It differs from typical specimens of $G$. suteri because of a more oval axial profile in the smaller last chamber.
Globorotaloides testarugosa Jenkins, 1960) (= Globorotalia testarugosa Jenkins). See Jenkins (1960), pl. 5, figs. 8a-8c; Pujol (1984), pl. 13, figs. 2-3. In this area typical G. testarugosa, with straight and tangential sutures on the spiral side, are rare and limited to Core $114-703 \mathrm{~A}-6 \mathrm{H}$, attributed to the P22-"N4" zonal interval of late Oligocene-early Miocene age.

Globorotaloides turgida (Finlay, 1939) (= Globigerina turgida Finlay). See Jenkins (1971), pl. 23, figs. 656-658.

Globorotaloides sp. 1. (Pl. 4, Figs. 6-9; Pl. 6, Figs. 19-22). We include in this informal species several small forms $(<150$ $\mu \mathrm{m})$ that possess a globorotaliform inner coiling mode resulting in a subacute lateral profile associated with subspherical outer chambers increasing abrubtly in size as added, a very coarse honeycomb wall structure particularly evident in the last chambers, and an umbilical-extraumbilical aperture bordered by a distinct rim. Sutures of the inner spire are curved, then depressed and radial to slightly curved in the last whorl. Globorotaloides $\mathrm{sp} .1$ shows some similarities with Globorotaloides variabilis Bolli, from which it can be distinguished by having fewer chambers, abruptly increasing in size, in the last whorl (no more than four in the Eocene, and four to five in the Oligocene forms); a more closed umbilicus; and a much coarser wall structure in the last chambers. It occurs almost continuously from late Paleocene through the Oligocene; it is particularly abundant in Zones P10-11 and P18, where it also increases in size $(>150 \mu \mathrm{m})$. It seems a potential climatic index species.

Guembelitria stavenisis Bandy, 1949. (Pl. 5, Fig. 10). Jenkins (1974), fig. 1. This form is very tiny, rare, with a short range confined to the upper part of Zone P21a before the chiloguembelinid extinction. Rare forms show holes in the adult chambers, but the specimens are too rare and badly preserved for distinguishing dissolution holes from the real secondary apertures, which are typical of Jenkinsina (= Guembelitria) samwelli (Jenkins, 1978a).

Morozovella aequa (Cushman and Renz, 1942) (= Globorotalia crassata (Cushman) var. aequa Cushman and Renz). See Toumarkine and Luterbacher (1985), fig. 15 (1-3).

Morozovella angulata (White, 1928) (= Globigerina angulata White). See Luterbacher (1964), figs. 37-39.

Morozovella angulata abundocamerata (Bolli, 1957) (= Globorotalia angulata abundocamerata Bolli). See Luterbacher (1964), figs. 41,42 .

Morozovella aragonensis (Nuttall, 1930) (= Globorotalia aragonenis Nuttall). (PI. 2, Fig. 6). Blow (1979), pl. 141, figs. 4-9. Rare specimens belonging to this species occur in the sediments of the studied area and are mainly transitional to the more common Morozovella crater.

"Morozovella" boudreauxi (Fleisher, 1974). See Fleisher (1974), pl. 1, figs. 2-5.

"Morozovella" broedermanni (Cushman and Bermudez) (= Globorotalia (Truncorotalia) broedermanni Cushman and Bermudez). See Toumarkine and Luterbacher (1985), fig. 29 (14-20).

"Morozovella" convexa (Subbotina, 1953)(= Globorotalia convexa Subbotina). See Subbotina (1953), pl. XVII, figs. 2-3.

Morozovella cf. crassata densa (Cushman, 1925) (= Pulvinulina crassata var. densa Cushman). See Toumarkine and Luterbacher (1985), fig. 29 (1).

Morozovella crater (Finlay, 1939) (= Globorotalia crater Finlay). (Pl. 2, Figs. 4-5). Blow (1979), pl. 134, figs. 8-9. Besides some typical specimens, several individuals can be referred to Globorotalia aragonensis Nuttall var. twisselmanni Mallory, 1959, which is considered a junior synonym of Morozovella crater by Blow (1979).

Morozovella dolabrata (Jenkins, 1971) (= Globorotalia (Morozovella) dolabrata Jenkins). (PI. 2, Figs. 7-9). Jenkins (1971), pl. 10, figs. 233-241. 
"Morozovella" edita (Subbotina, 1953) (= Globigerina edita Subbotina). See Subbotina (1953), pl. II, figs. 1a-1c.

Morozovella gracilis (Bolli, 1957) (= Globorotalia formosa gracilis Bolli). See Bolli (1957c), pl. 18, figs. 4-6.

Morozovella hispidicidaris (Loeblich and Tappan, 1957) (= Globorotalia hispidicidaris Loeblich and Tappan). See Loeblich and Tappan (1957), pl. 58, figs. 1a-1c.

"Morozovella" inconstans (Subbotina, 1953) (= Globigerina inconstans Subbotina). See Subbotina (1953), pl. III, figs. $1 \mathrm{a}-1 \mathrm{c}, 2 \mathrm{a}-2 \mathrm{c}$.

"Morozovella" indolensis (Morozova, 1959) (= Acarinina indolensis Morozova). See Luterbacher (1964), figs. 33 and 34.

Morozovella kubanensis (Shutskaya, 1956) (= Globorotalia kubanensis Shutskaya). See Luterbacher (1964), fig. 43.

Morozovella cf. lehneri (Cushman and Jarvis, 1929) (= Globorotalia lehneri Cushman and Jarvis). See Toumarkine and Luterbacher (1985), fig. 31 (11-13).

Morozovella lensiformis (Subbotina, 1953) (= Globorotalia lensiformis Subbotina). See Subbotina (1953), pl. XVIII, figs. 4-5; Blow (1979), pl. 126, figs. 1-3, 5, 6.

Morozovella marginodentata (Subbotina, 1953) (= Globorotalia marginodentata Subbotina). (PI. 2, Figs. 1-3). Subbotina (1953), pl. XVII, figs. 14-16; pl. XVIII; figs. 3a-3c.

"Morozovella" nicoli (Martin, 1984) (= Globorotalia nicoli Martin). (Pl. 4, Figs. 10-12). Martin (1943), pl. 7, fig. 3; Blow (1979), pl. 97, figs. 1, 2, 6.

"Morozovella" nicoli ? salisburgensis (Gorbandt, 1967) (= ?Globorotalia salisburgensis). (PI. 4, Figs. 13-15). Blow (1979), pl. 97, figs. 3-5.

"Morozovella" praecursoria (Morozova, 1957) (= Acarinina praecursoria Morozova). See Toumarkine and Luterbacher (1985), fig. $13(5 \mathrm{a}-5 \mathrm{c})$.

Morozovella pusilla (Bolli, 1957) (= Globorotalia pusilla pusilla Bolli). See Toumarkine and Luterbacher (1985), fig. 12 (13-14).

"Morozovella" schachdagica (Khalilov, 1956) (= Globigerina schachdagica Khalilov). See Luterbacher (1964), fig. 24.

Morozovella simulatilis (Schwager, 1883) (= Discorbina simulatilis Schwager). See Luterbacher (1964), figs. 53-55.

Morozovella spinulosa (Cushman, 1927) (= Globorotalia spinulosa Cushman). See Toumarkine and Luterbacher (1985), fig. 30 (1-2). The specimens attributed to this taxon, according to Cushman's description, have a very faint muricocarina (formerly carena) and are small and delicate.

Morozovella subbotinae (Morozova, 1929) (= Globorotalia subbotinae Morozova). See Toumarkine and Luterbacher (1985), fig. 15 (9-11).

Morozovella tadjikistanensis (Bykova, 1953) (= Globorotalia tadjikistanensis Bykova). See Luterbacher (1964), fig. 52.

"Morozovella" tadjikistanensis djanensis (Shutskaya, 1963) (= Globorotalia tadjikistanensis djanensis Shutskaya). See Tjalsma (1977), pl. 1, figs. 9-12.

"Morozovella" trinidadensis (Bolli, 1957) (= Globorotalia trinidadensis Bolli). See Bolli (1957c), pl. 16, figs. 19-23.

Morozovella wilcoxensis berggreni (El-Naggar, 1966) (= Globorotalia berggreni El-Naggar). See Blow (1979), pl. 114, figs. $7,9,10$.

"Morozovella" uncinata (El-Naggar, 1966) (= Globorotalia woodi El-Naggar). See El-Naggar (1966), pl. 23, figs. 2a-2c.

"Morozovella" uncinata (Bolli, 1957) (Globorotalia uncinata Bolli). See Bolli (1957c), pl. 17, figs. 13-15.

Paragloborotalia opima nana (Bolli, 1957) (= Globorotalia opima nana, Bolli). See Bolli (1957b), pl. 28, figs. 3a-3c.

Paragloborotalia opima opima (Bolli, 1957) (= Globorotalia opima opima Bolli). See Bolli (1957b), pl. 28, figs. 1a-2.
Paragloborotalia pseudocontinuosa (Jenkins, 1967) (= Globorotalia pseudocontinuosa Jenkins). Jenkins and Srinivasan (1986), pl. 5, figs. 2-4. In our material transitional forms between $P$. opima nana and $P$. pseudocontinuosa are common when $P$. opima nana occurs either in the late Eocene or in the Oligocene. In the Oligocene some specimens show a tendency to have five chambers in the last whorl.

Paragloborotalia semivera (Hornibrook, 1961) (= Globigerina semivera Hornibrook). See Kennett and Srinivasan (1983), pl. 42, figs. 3-5.

Planorotalites archeocompressus Blow 1979 (= Globorotalia (Turborotalia) archeocompressa Blow). See Blow (1979), pl. 58, figs. 6-9.

Planorotalites australiformis (Jenkins, 1971) (= Globorotalia (Planorotalites) australiformis Jenkins). See Jenkins (1971), pl. 10, figs. 242-244.

Planorotalites chapmani (Parr, 1938) (= Globorotalia chapmani Parr). See Parr (1938), pl. 9, figs. 8-9.

"Planorotalites chapmani" sensu Berggren, Olsson, and Reyment, 1967. See Blow (1979), pl. 116, figs. 1-3.

Planorotalites compressus (Plummer, 1926) (= Globigerina compressa Plummer). See Toumarkine and Luterbacher (1985), fig. 12 (1-2).

Planorotalites ehrenbergi (Bolli, 1957) $(=$ Globorotalia ehrenbergi Bolli). (Pl. 1, Figs. 1-3). See Sigal (1974), pl. 4, figs. $5 \mathrm{a}-5 \mathrm{c}$.

Planorotalites cf. eugubinus (Luterbacher and Premoli Silva, 1964) (= Globigerina eugubina Luterbacher and Premoli Silva). See Stainforth et al. (1975), fig. 47 (1-6).

Planorotalites imitata (Subbotina, 1953) (= Globorotalia imitata Subbotina). See Subbotina (1953), pl. XVI, figs. 14a$14 \mathrm{c}, 15 \mathrm{a}-15 \mathrm{c}, 16 \mathrm{a}-16 \mathrm{c}$.

Planorotalites planoconicus (Subbotina, 1953) (= Globorotalia planoconica Subbotina). See Blow (1979), pl. 159, figs. $1-5$; pl. 161, figs. 1, 8, 9.

Planorotalites pseudomenardii (Bolli, 1957) (= Globorotalia pseudomenardii Bolli). (PI. 1, Figs. 7-9). See Bolli (1957c), pl. 20, figs. 14-17.

Planorotalites pseudoscitulus (Glaessner, 1937) (= Globorotalia pseudoscitula Glaessner). See Blow (1979), pl. 173, fig. 1-8.

Planorotalites pseudoscitulus elongatus (Glaessner, 1937) (= Globorotalia pseudoscitula var. elongata Glaessner). (PI. 1, Figs. 10-12). Blow (1979), pl. 105, figs 1, 2, 4-6.

"Praetenuitella" insolita (Jenkins, 1966). (PI. 4, Figs. 24-26). Jenkins and Srinivasan (1986), pl. 3, figs. 3, 4. This forms is a very important stratigraphic marker because it has a short range from the upper Eocene to the basal Oligocene. It probably evolved from Tenuitella reissi after a significant modification of the aperture, which becomes a very high and narrow arch extending parallel to the margin but not on the margin as in the typical Praetenuitella. 6-10.

Praetenuitella patefacta Li, 1987. See Li (1987), pl. 1, figs.

?Prosphaeroidinella sp. (Pl. 5, Figs. 13, 14). Here in the Oligocene are transitional specimens between "Globigerina" labiacrassata and very thick-walled and closed forms, morphologically similar to the taxon Prosphaeroidinella Ujiié, 1976 (early Miocene to Holocene) without any smooth outer cortex. However, this apparent similarity can be attributed to an intense secondary calcification that produces an almost straight aperture heavily covered with secondary calcite.

Pseudohastigerina barbadoensis Blow, 1969. See Blow (1969), pl. 53, figs. 7-9.

Pseudohastigerina danvillensis (Howe and Wallace, 1932) (= Nonion danvillensis). (Pl. 4, Fig. 16). Blow (1979), pl. 253, figs. 10-12. This form appears in Zone P9 (= Morozovella 
crater Zone) and becomes typical and increases in abundance in the lower middle Eocene.

Pseudohastigerina micra (Cole, 1927) (= Nonion micrus Cole). See Blow (1979), pl. 253, figs. 1-9.

Pseudohastigerina sharkriverensis Berggren, Olsson, and Reyment, 1967. (Pl. 2, Figs. 18, 19). Berggren et al. (1967), p1. 1, figs. $4 \mathrm{a}-4 \mathrm{~b}$.

Pseudohastigerina wilcoxensis (Cushman and Ponton, 1932) (= Nonion wilcoxensis Cushman and Ponton). See Berggren et al. (1967), text-fig. 2. In the studied area this species ranges from the base of the lower Eocene to the middle Eocene, although it is very rare in the middle Eocene.

Subbotina angiporoides (Hornibrook, 1965) (= Globigerina angiporoides Hornibrook). (Pl. 6, Fig. 18). Hornibrook (1965), pls. 1a-1i, 2.

Subbotina angiporoides minima (Jenkins, 1966) (= Globigerina angiporoides Hornibrook subsp. minima Jenkins). (Pl. 6, Figs. 13-15). Jenkins (1966), fig. 7, nos. 52-57.

Subbotina ayalai (Bermudez, 1961) (= Globigerina ayalai Bermudez). See Bermudez (1961), pl. 1, figs. 4a-4c.

Subbotina cf. azerbaidjanica (Khalilov, 1956) (= Globigerina azerbaidjanica Khalilov). See Khalilov (1956), pl. 4, figs. 1a-1c.

Subbotina bakeri (Cole, 1927) (= Globigerina bakeri Cole). See Bermudez (1961), pl. 1, figs. 5a-5c.

Subbotina brevis (Jenkins, 1966.) (= Globigerina brevis Jenkins). See Jenkins (1985), fig. 6(17a-17c). This form is very rare.

Subbotina corpulenta (Subbotina, 1953) (= Globigerina corpulenta Subbotina). See Subbotina (1953), pl. 10, figs. 1-4. The specimens attributed to this species tend to increase the height of the spire toward the Subbotina praeturritilina (Blow and Banner, 1962) stage.

Subbotina crassa (Shutskaya, 1970) (= Globigerina crassa Shutskaya). See Shutskaya (1970), pl. 22, figs. 1a-1c; pl. 24, figs. $9 \mathrm{a}-9 \mathrm{c}$.

Subbotina crociapertura Blow, 1979. See Blow (1979), pl. 176, figs. 1-9.

"Subbotina" danica (Bang, 1969) (= Globigerina danica Bang). See Bang (1969), pl. 1, figs. 1a-1c, 2a-2c, 3a-3c.

Subbotina eobulloides (Morozova, 1959) (= Globigerina (Eoglobigerina) eobulloides Morozova). See Ellis and Messina (1940), pl. 1a-1c.

Subbotina eocaena (Guembel, 1868) (= Globigerina eocaena Guembel). See Hagn and Lindenberg (1969), pl. 1, figs. $1 \mathrm{a}-1 \mathrm{c}$. This species includes several specimens with a final more or less large abortive chamber.

Subbotina eocaenica (Terquem, 1882) (= Globigerina eocaenica Terquem). (PI. 6, Figs. 4-6). Subbotina (1953), p. $\mathrm{XI}$, figs. $8-11$. This form is not easily distinguished from Subbotina utilisindex, with which it coexists in Zones P1112. The main difference between the two taxa consists in the nature of the aperture: Subbotina eocaenica possesses a slightly arched, umbilical-extraumbilical aperture, with a moderately thin curved rim that never extends to the peripheral margin, whereas Subbotina utilisindex has a slitlike aperture or an elongate low arch that extends almost to the peripheral margin, with a straight and well-developed lip. In the lower Eocene Subbotina eocaenica is transitional to Subbotina eocaenica irregularis whereas Subbotina utilisindex, which appears in the lower middle Eocene in this area, is related to Subbotina angiporoides.

Subbotina eocaenica irregularis (Subbotina, 1953) (= Globigerina eocaenica var. irregularis Subbotina). (Pl. 6, Figs. 7-9). Subbotina (1953), pl. XI, figs. 12a, 12b, 12c.

"Subbotina" fringa (Subbotina, 1953) (= Globigerina fringa Subbotina). See Subbotina (1953), pl. III, figs. 3a-3c, 4a-4c.
Subbotina gortanii (Borsetti, 1959) (= Catapsydrax gortanii Borsetti). See Borsetti (1959), pl. 1, figs. 1a-1c.

Subbotina hagni (Gohrbrandt, 1967) (= Globigerina hagni Gohrbandt). See Toumarkine and Luterbacher (1985), fig. 42 (7-9).

Subbotina higginsi (Bolli, 1957) (= "Globigerinoides" higginsi Bolli). (Pl. 2, Fig. 17). Bolli (1957a), pl. 36, figs. 11-13. In the lower Eocene a few specimens display a morphology very close to that of "Globigerinoides" higginsi without clearly showing the secondary sutural apertures. They seem to be high-spired variants of Subbotina lozanoi (see Pl. 2, Figs. 13-16) in agreement with Blow (1979). These forms are confined to the lower Eocene.

Subbotina aff. hornibrooki Brönnimann, 1952) (= Globigerina hornibrooki Brönnimann). See Blow (1979), pl. 124, figs. 7, 8.

Subbotina inaequispira (Subbotina, 1953) (= Globigerina inaequispira Subbotina). See Subbotina (1953), p. VI, figs. 1-4. The specimens herein found show a more restricted umbilical area than the holotype illustrated by Subbotina.

Subbotina linaperta group (Finlay, 1939) (= Globigerina linaperta Finlay). (Pl. 6, Figs. 26-31). Hornibrook (1958), pl. 1, figs. 19-21; Krasheninnikov and Basov (1983), pl. 2, figs. 8-11. The main characteristics of this species are the flattening of the last chamber to assume a kidney-shaped form, ellipsoidal in side view, and a very coarse hexagonal pore ridges. Aside from typical forms like the holotype, our material commonly contains specimens more tightly coiled with an aperture variably arched in the middle portion (Pl. 6, Figs. 26-28). They are similar to the variety of S. linaperta illustrated by Lindsay (1985, fig. 14) from topotype material. For the time being, all the illustrated morphotypes are included in the $S$. linaperta group. Further studies are needed to clarify the relationship among these forms. Subbotina linaperta s. str. and associated forms appeared in the late middle Eocene (Zones P12-13) and became extinct in the late Eocene.

Subbotina lozanoi (Colom, 1954) (= Globigerina lozanoi Colom). (Pl. 2, Figs. 13-16). Toumarkine and Luterbacher (1985), fig. 28 (6-11). Rare specimens have been attributed to Subbotina lozanoi, some of which show secondary sutural apertures (see Pl. 2, Fig. 16).

Subbotina patagonica (Todd and Kniker, 1952) (= Globigerina patagonica Todd and Kniker). (Pl. 6, Figs. 1-3). Todd and Kniker (1972), pl. 4, fig. 32. The main characteristics of this species are the size of the last chamber, which makes up almost half of the entire final whorl, the highly arched primary aperture, and the finely cancellate wall. It has been found mainly in the lower Eocene, where it shows some relationship with the $S$. eocaenica group.

"Subbotina" pseudobulloides (Plummer, 1926) (= Globigerina pseudobulloides Plummer). See Toumarkine and Luterbacher (1985), fig. 14 (1-2).

Subbotina pseudoecaena compacta (Subbotina, 1953) (= Globigerina pseudoeocaena var. compacta Subbotina). See Subbotina (1953), pl. V, figs. 3a, 3b, 3c.

Subbotina pseudoecaena (Subbotina, 1953) (= Globigerina pseudoeocaena var. pseudoeocaena Subbotina). See Subbotina (1953), pl. V, figs. 1-2.

Subbotina pseudoeocaena trilobata (Subbotina, 1953) (= Globigerina pseudoeocaena var. trilobata Subbotina). See Subbotina (1953), pl. V, figs. 5a-5c.

Subbotina ratusa (Kopayevich, 1970) (= Globigerina ratusa Kopayevich). (PI. 1, Figs. 27-28). Ellis and Messina (1940), pl. 3, figs. 2a-2c. This species is distinguished from $S$. inaequispira because the chambers in the last whorl remain uniform in size, the umbilical area is closed, and the coiling is tight. 
Subbotina triangularis (White, 1928) $(=$ Globigerina triangularis White). See Shutskaya (1970), pl. XXIII, figs. 1A-1B.

Subbotina triloculinoides (Plummer, 1926) (= Globigerina utilisindex Plummer). See Toumarkine and Luterbacher (1985), fig. 19 (1-2)

Subbotina utilisindex (Jenkins and Orr, 1973) (= Globigerina utilisindex Jenkins and Orr). (Pl. 6, Figs. 10-12, 16, 17). Jenkins and Orr (1973), pl. 1, figs. 1-6; pl. 2, figs. 1-9; pl. 3, figs. 1-3. The main characteristics of this species are the round final chamber and a finer wall structure than in the $S$. linaperta group. In topotypic material, $S$. utilisindex from subantarctic sites displays a constantly slitlike aperture, located umbilically-extraumbilically, always bordered by a distinct imperforate lip, which allows us to link this species to $S$. angiporoides. Subbotina utilisindex has a longer range than $S$. linaperta s. str. and disappeared in the early Oligocene together with $S$. angiporoides and $S$. angiporoides minima.

Subbotina yeguaensis (Weinzierl and Applin, 1929) (= Globigerina yeguaensis Weinzierl and Applin). Weinzierl and Applin (1929), pl. 43, figs. 1a-1b.

Tenuitella clemenciae (Bermudez, 1961) $(=$ Turborotalia clemenciae Bermudez). (Pl. 5, Figs. 1, 2). Bermudez (1961), pl. 17 , fig. 10 .

Tenuitella gemma (Jenkins, 1971) $(=$ Globorotalia (Turborotalia) gemma Jenkins). See Jenkins (1971), pl. 10, figs. 263-269.

Tenuitella minutissima (Bolli, 1957) (= globorotalia minutissima Bolli). See Li (1987), fig. 3 (16-18).

Tenuitella munda (Jenkins, 1966) (= Globorotalia munda Jenkins). See Jenkins (1966), figs. 14, 15.

Tenuitella cf. pseudoedita (Subbotina, 1960) (= Globigerina pseudoedita Subbotina). See Ellis and Messina (1940), pl. 11 , figs. 1-3.

Tenuitella reissi (Loeblich and Tappan, 1957) (= Globigerina ciperoensis Loeblich and Tappan). See Loeblich and Tappan (1957), pl. 50, figs. 3a-3c; pl. 58, figs. 3a-3c. This form displays a long range, from early Paleocene to middle Eocene.

Tenuitellinata angustiumbilicata (Bolli, 1957) (= Globigerina ciperoensis angustiumbilicata Bolli). See Li (1987), pl. 2, figs. $15,17-19$.

Turborotalia cerroazulensis frontosa (Subbotina, 1953) (= Globigerina frontosa Subbotina). See Toumarkine and Luterbacher (1985), fig. 35 (16-18). This species is extremely rare in the subantarctic.

\section{ACKNOWLEDGMENTS}

The senior author is indebted to the Ocean Drilling Program for having invited her to participate to Leg 114.

The authors would like to thank A. Boersma and M. B. Cita for their constructive reviews of the final manuscript. Their warm thanks go also to Armando Bartolucci, University of Perugia, and Gabriele Pezzi, University of Milan, for technical assistance; to Agostino Rizzi, Centro Alpi, CNR di Milano, for SEM micrographs; to Giampiero Tosti, University of Perugia, for printing photographs and preparing tables and plates; and to Dr. P. Monaco for priceless software assistance.

Participation on ODP Leg 114 and this work were supported by CNR Contribution Number 88.01643.05. to M. Nocchi.

\section{REFERENCES}

Akers, W. H., 1955. Some planktonic foraminifera of the American Gulf Coast and suggested correlations with the Caribbean Tertiary. J. Paleontol., 29:647-664.

Bang, I., 1969. Planktonic foraminifera and biostratigraphy of the type Danian. In Brönnimann, P., and Renz, H. H. (Eds.), Proc. 1st Int. Planktonic Microfossils Conf., 1:58-65.
Barker, P. F., and Burrell, J., 1977. The opening of Drake Passage. Mar. Geol., 25:15-34.

Barker, P. F., Kennett, J. P., et al., 1988. Proc. ODP, Init. Repts, 113: College Station, TX (Ocean Drilling Program).

Bé, A.W.H., and Tolderlund, D. S., 1971. Distribution and ecology of living planktonic foraminifera in surface waters of the Atlantic and Pacific oceans. In Funnel, B. M., and Riedel, W. R. (Eds.), Micropaleontology of the Oceans: Cambridge (Cambridge Univ. Press), 105-149.

Beckmann, J. P., 1957. Chiloguembelina Loeblich and Tappan and related Foraminifera from the lower Tertiary of Trinidad, B.W.I. Bull. U.S. Nat. Mus., 215:83-95.

Berger, W. H., and von Rad, U., 1972. Cretaceous and Cenozoic sediments from the Atlantic Ocean. In Hayes, D. E., Pimm, A. C. et al., Init. Repts. DSDP, 14: Washington (U.S. Govt. Printing Office), 787-954.

Berggren, W. A., Kent, D. V., and Flynn, J. J., 1985. Jurassic to Paleogene: part 2. Paleogene geochronology and chronostratigraphy. In Snelling, N. J. (Ed.), The Chronology of the Geological Record: Geol. Soc. London Mem., 10:141-195.

Berggren, W. A., Olsson, R. K., and Reyment, R. A., 1967. Origin and development of the foraminiferal genus Pseudohastigerina Banner and Blow. Micropaleontology, 13:265-288.

Bermudez, P. J., 1961. Contribuciön al estudio de las Globigerinidae de la regiön Caribe-Antillana (Paleocene-Recente). Memorias de la III Congreso Geologico Venezolano, tomo III. Soc. Geol. Venez., Bol. Geol., Publ. Espec., 3:1119-1393.

Blow, W. H., 1969. Late middle Eocene to Recent planktonic foraminiferal biostratigraphy. In Brönnimann, P., and Renz, H. H. (Eds.), Proc. 1st Int. Planktonic Microfossils Conf., 1:199-422. 1979. The Cainozoic Globigerinida: Leiden (E. J. Brill).

Blow, W. H., and Banner, F. T., 1962. The Mid-Tertiary (upper Eocene to Aquitanian) Globigerinacea. In Eames, F. E., Banner, F. T., Blow, W. H., and Clarke, W. J. (Eds.), Fundamentals of Mid-Tertiary Stratigraphical Correlation: Cambridge (Cambridge Univ. Press), 61-151.

Boersma, A., 1977. Cenozoic planktonic foraminifera, DSDP Leg 39 (South Atlantic). In Perch-Nielsen, K., Supko, P. R., et al., Init. Repts. DSDP, 39: Washington (U.S. Govt. Printing Office), 567590.

Boersma, A., and Premoli Silva, I., 1983. Paleocene planktonic foraminiferal biogeography and the paleoceanography of the Atlantic Ocean. Micropaleontology, 29:355-381.

1986. Terminal Eocene events: planktonic foraminiferal and isotopic evidence. In Pomerol, C., and Premoli Silva, I. (Eds.), Terminal Eocene Events: New York (Elsevier), 213-224. 1989. Atlantic Paleogene biserial heterohelicids and oxygen minima. Paleoceanography, 4:271-286.

Boersma, A., Premoli Silva, I., and Shackleton, N. J., 1987. Atlantic Eocene planktonic foraminiferal paleohydrographic indicators and stable isotope paleoceanography. Paleoceanography, 2:287-331.

Boersma, A., and Shackleton, N. J., 1977. Tertiary oxygen and carbon isotope stratigraphy, Site 357 (mid-latitude South Atlantic). In Perch-Nielsen, K., Supko, P. R., et al., Init. Repts. DSDP, 39: Washington (U.S. Govt. Printing Office), 911-924.

Bolli, H. M., 1957a. Planktonic foraminifera from the Eocene Navet and San Fernando formations of Trinidad, B.W.I. Bull. U.S. Nat. Mus., 215:155-172.

1957b. Planktonic foraminifera from the Oligocene-Miocene Cipero and Lengua formations of Trinidad, B.W.I. Bull. U.S. Nat. Mus., 215:97-124.

1957c. The genera Globigerina and Globorotalia in the Paleocene-lower Eocene Lizard Springs Formation of Trinidad, B.W.I. Bull. U.S. Nat. Mus., 215:61-82.

1972. The Genus Globigerinatheka Brönnimann. J. Foraminiferal Res., 2:109-136.

Bolli, H. M., and Saunders, J. B., 1985. Oligocene to Holocene low latitude planktonic foraminifera. In Bolli, H. M., Saunders, J. B., and Perch-Nielsen, K. (Eds.), Plankton Stratigraphy: Cambridge (Cambridge Univ. Press), 155-262.

Bolli, H. M., Saunders, J. B., and Perch-Nielsen, K., 1985. Introduction to foraminiferal chapters. In Bolli, H. M., Saunders, J. B., and Perch-Nielsen, K. (Eds.), Plankton Stratigraphy: Cambridge (Cambridge Univ. Press), 11-16. 
Borsetti, A. M., 1959. Tre nuovi Foraminiferi planctonici dell'Oligocene piacentino. G. Geol., 27:205-212.

Brönnimann, P., 1952. Trinidad Paleocene and lower Eocene Globigerinidae. Bull. Am. Paleontol., 34:1-34.

Brönnimann, P., and Bermudez, P. J., 1953. Truncorotaloides, a new foraminiferal genus from the Eocene of Trinidad, B.W.I. J. Paleontol, 27:817-820.

Brönnimann, P., and Resig, J., 1971. A Neogene globigerinacean biochronologic timescale of the Southwestern Pacific. In Winterer, E. L., Riedel, W. R., et. al., Init. Repts. DSDP, 7: Washington (U.S. Govt. Printing Office), 1235-1409.

Chapronière, G.C.H., 1988. Globigerina woodi from the late Oligocene and early Miocene of southeastern Australia. J. Foraminiferal Res., 18:124-129.

Ciesielski, P. F., Kristoffersen, Y., et al., 1988. Proc. ODP, Init. Repts., 114: College Station, TX (Ocean Drilling Program).

Cifelli, R., 1972. The holotypes of Pulvinulina crassata var. densa Cushman and Globigerina spinuloinflata Bandy. J. Foraminiferal Res., 2:157-159.

Davidzon, R. M., and Morozova, V. G., 1964. Planktonic and benthonic foraminifera from the Bukhara Beds (Paleocene) of the Tadzhik depression. Paleontol. Zh., 3:20-29.

Edwards, A. R., and Hoskins, R. H., 1982. International correlation in stages of the New Zealand marine Cenozoic: a synopsis. N.Z. Geol. Surv. Bull., 107:28-32.

Ellis, B. F., and Messina, A., 1940. Catalogue of foraminifera. Am. Mus. Nat. Hist.: New York (Micropaleontology Press).

El-Naggar, Z. R., 1966. Stratigraphy and planktonic foraminifera in the Upper Cretaceous-lower Tertiary succession in the Esna-Idfu region, Nile Valley, Egypt, U.A.R. London Br. Mus. (Nat. Hist. Bull. Geol., Suppl., 2:1-291.

Fleisher, R. L., 1974. Cenozoic planktonic foraminifera and biostratigraphy, Arabian Sea Deep Sea Drilling Project, Leg 23A. In Whitmarsh, R. B., Weser, O. E., Ross, D. A., et al., Init. Repts. DSDP, 23: Washington (U.S. Govt. Printing Office), 1001-1072.

Hagn, H., and Lindenberg, H. G., 1969. Revision der von Guembel 1868 aus dem Eozån des bayerischen Alpenvorlandes beschribenen planktonishen Foraminiferen. In Brönnimann, P., and Renz, H. H. (Eds.), Proc. 1st Int. Planktonic Microfossils Conf., 2:229250.

Haq, B. U., Premoli Silva, I., and Lohmann, G. P., 1977. Calcareous plankton paleobiogeographic evidence for major climatic fluctuations in the early Cenozoic Atlantic Ocean. J. Geophys. Res., 82:3861-3876.

Hornibrook, N. de B., 1958. New Zealand foraminifera: key species in stratigraphy, no. 6. N.Z. J. Geol. Geophys., 1:653-676. 1965. Globigerina angiporoides $\mathrm{n}$. sp. from the upper Eocene and lower Eocene of New Zealand and the status of Globigerina angipora Stache, 1865. N.Z. J. Geol. Geophys., 8:834-838.

Jenkins, D. G., 1960. Planktonic foraminifera from the Lakes Entrance oil shaft, Victoria, Australia. Micropaleontology, 6:345-371.

1965. A re-examination of Globorotalia collactea Finlay, 1939. N.Z. J. Geol. Geophys., 8:844-848.

1966. Planktonic foraminiferal zones and new taxa from the Danian to lower Miocene of New Zealand. N.Z. J. Geol. Geophys., 8:1088-1126.

1968. Variations in the number of species and subspecies of planktonic foraminiferida as an indicator of New Zealand Cenozoic paleotemperatures. Palaeogeogr., Palaeoclimatol., Palaeoecol., 5:309-313.

1971. Cenozoic planktonic foraminifera of New Zealand. N.Z. Geol. Surv. Paleontol. Bull, 42:1-278.

1973. Diversity changes in the New Zealand Cenozoic planktonic foraminifera. J. Foraminiferal Res., 3:78-88.

1974. Initiation of the ProtoCircum-Antarctic Current. Nature, 252:371-373.

1978a. Guembelitria samwelli Jenkins, a new species from the Oligocene of the Southern Hemisphere. J. Foraminiferal Res., 8:132-137.

1978b. Neogene planktonic foraminifers from DSDP Leg 40 Sites 360 and 361 in the Southeastern Atlantic. In Bolli, H. M., Ryan, W.B.F., et al., Init. Repts. DSDP, 40: Washington (U.S. Govt. Printing Office), 723-738.
1985. Southern mid-latitude Paleocene to Holocene planktic foraminifera. In Bolli, H. M., Saunders, J. B., and PerchNielsen, K. (Eds.), Plankton Stratigraphy: Cambridge (Cambridge Univ. Press), 263-282.

Jenkins, D. G., and Orr, W. N., 1973. Globigerina utilisindex n. sp. from the upper Eocene-Oligocene of the eastern equatorial $\mathrm{Pa}$ cific. J. Foraminiferal Res., 3:133-135.

Jenkins, D. G., and Srinivasan, M. S., 1986. Cenozoic planktonic foraminiferal biostratigraphy of the southwestern Pacific and Tasman Sea. In Kennett, J. P., von der Borch, C. C., et al., Init. Repts. DSDP, 90: Washington (U.S. Govt. Printing Office), 795834.

Keigwin, L. D., Jr., and Corliss, B. H., 1986. Stable isotope in late middle Eocene to Oligocene Foraminifera. Geol. Soc. Am. Bull., 97:335-345.

Kennett, J. P., 1977. Cenozoic evolution of Antarctic glaciation, the Circum-Antarctic Ocean, and their impact on global paleoceanography. J. Geophys. Res., 82:3843-3860.

1978. The development of planktonic biogeography in the Southern Ocean during the Cenozoic. Mar. Micropaleontol., 3:301-345.

Kennett, J. P., and Srinivasan, M. S., 1983. Neogene Planktonic Foraminifera: A Phylogenetic Atlas: Stroudsburg, PA (Hutchinson Ross).

Khalilov, D. M., 1956. On the pelagic foraminiferal fauna of the Paleogene of Azerbaidzhan. Akad. Nauk Azerb. S.S.R., Inst. Geol., 17:1-255.

Krasheninnikov, V. A., and Basov, I. A., 1983. Cenozoic planktonic foraminifers of the Falkland Plateau and Argentine Basin, Deep Sea Drilling Project Leg 71. In Ludwig, W. J., Krasheninnikov, V. A., et al., Init. Repts. DSDP, 71: Washington (U.S. Govt. Printing Office), 821-858.

1986. Late Mesozoic and Cenozoic stratigraphy and geological history of the South Atlantic high latitudes. Palaeogeogr., Palaeoclimatol., Palaeoecol., 55:145-188.

LaBrecque, J. L. (Ed.), 1986. South Atlantic Ocean and Adjacent Continental Margin: Ocean Margin Drilling Program Reg. Atlas Ser., 13.

LaBrecque, J. L., and Hayes, D. E., 1979. Sea floor spreading in the Agulhas Basin. Earth Planet Sci. Lett., 45:411-428.

Le Roy, L. W., 1953. Biostratigraphy of the Maqfi section, Egypt. Mem. Geol. Soc. Am., 54:1-73

$\mathrm{Li}$, O., 1987. Origin, phylogenetic development and systematic taxonomy of the Tenuitella plexus (Globigerinitidae, Globigerinina). J. Foraminiferal Res., 17:298-320.

Lindsay, J. M., 1985. Aspects of South Australian Tertiary foraminiferal biostratigraphy, with emphasis on studies of Massilina and Subbotina. Spec. Publ. S. Aust. Dep. Mines Energy, 5:187-231.

Loeblich, A. R., Jr., and Tappan, H., 1957. Planktonic foraminifera of Paleocene and early Eocene age from the Gulf and Atlantic coastal plains. Bull. U.S. Nat. Mus., 215:173-198.

Lowrie, W., Alvarez, W., Napoleone, G., Perch-Nielsen, K., Premoli Silva, I., and Toumarkine, M., 1982. Paleogene magnetic stratigraphy in Umbrian pelagic carbonate rocks: the Contessa sections, Gubbio. Geol. Soc. Am. Bull., 93:414-432.

Ludbrook, N. H., and Lindsay, J. M., 1969. Tertiary foraminiferal zones in South Australia. In Brönnimann, P., and Renz, H. H. (Eds.), Proc. 1st Int. Planktonic Microfossils Conf., 2:366-375.

Luterbacher, H. P., 1964. Studies in some Globorotalia from the Paleocene and lower Eocene of the central Apennines. Eclogae Geol. Helv., 57:631-670.

Martin, L. T., 1943. Eocene foraminifera from the type Lodo Formation, Fresno County, California. Stanford Univ. Publ. Geol. Sci., 3:93-125.

McGowran, B., 1986. Cainozoic oceanic and climatic events: the Indo-Pacific foraminiferal biostratigraphic record. Palaeogeogr., Palaeoclimatol., Palaeoecol., 55:247-265.

McKeel, D. R., and Lipps, J. H., 1975. Eocene and Oligocene planktonic foraminifera from the central and southern Oregon Coast Range. J. Foraminiferal Res., 5:249-268.

Molina, E., 1979. Oligocene-Mioceno inferior por medio de foraminiferos planctonicos en el sector central de las Cordilleras Beticas (España) [Ph.D. thesis]. Publicacion Univ. de Granada y Zaragoza, Deposito Legal Z-804-80. 
Napoleone, G., Premoli Silva, I., Heller, F., Cheli, P., Corezzi, S., and Fischer, A. G., 1983. Eocene magnetic stratigraphy at Gubbio, Italy, and its implications for Paleogene geochronology. Geol. Soc. Am. Bull., 94:181-191.

Nocchi, M., Parisi, G., Monaco, P., Monechi, S., Madile, M., Napoleone, G., Ripepe, M., Orlando, M., Premoli Silva, I., and Rice, D. M., 1986. The Eocene-Oligocene boundary in the Umbrian pelagic sequences. In Pomerol, C., and Premoli Silva, I. (Eds.), Terminal Eocene Events: New York (Elsevier), 25-40.

Orr, W. N., and Jenkins, D. G., 1977. Cainozoic planktonic foraminifera zonation and selective test solution. In Ramsay, A.T.S. (Ed.), Oceanic Micropaleontology (vol.1): London (Academic Press), 163-196.

Palmer, D. K., 1934. The foraminiferal genus Guembelina in the Tertiary of Cuba. Mem. Soc. Cubana Hist. Nat., 8:73-76.

Parisi, G., Guerrera, F., Madile, M., Magnoni, G., Monaco, P., Monechi, S., and Nocchi, M., 1988. Middle Eocene to early Oligocene calcareous nannofossil and foraminiferal biostratigraphy in the Monte Cagnero section, Piobbico (Italy). In Premoli Silva, I., Coccioni, R., and Montanari, A. (Eds.), The EoceneOligocene Boundary in the Marche-Umbria Basin (Italy). Int. Subcomm. Paleogr. Strat., E/O Meeting, Ancona 1987, Spec. Publ., 119-136.

Parr, W. J., 1938. Upper Eocene foraminifera from deep borings in King's Park, Perth, Western Australia. J. R. Soc. West. Australia, 24:69-101.

Poore, R. Z., 1984. Middle Eocene through Quaternary planktonic foraminifers from the southern Angola basin. In Hsü, K. J., LaBrecque, J. L., et al., Init. Repts. DSDP, 73: Washington (U.S. Govt. Printing Office), 429-448.

Premoli Silva, I., and Boersma, A., 1988. Atlantic Eocene planktonic foraminiferal historical biogeography and paleohydrographic indices. Palaeogeogr., Palaeoclimatol., Palaeoecol., 67:315-356. , in press. Atlantic Paleogene planktonic foraminiferal bioprovincial indices. Mar. Micropaleontol.

Pujol, C., 1984. Cenozoic planktonic foraminiferal biostratigraphy of the southwestern Atlantic (Rio Grande Rise): Deep Sea Drilling Project Leg 72. In Barker, P. F., Carlson, R. L., Johnson, D. A., et al., Init. Repts. DSDP, 72: Washington (U.S. Govt. Printing Office), 623-668.

Pujol, C., and Sigal, J., 1979. Les Foraminifères Planctoniques Palécogènes du Site 245, Bassin de Madagascar-Biostratigraphie (DSDP, Leg 25): Bordeaux (CNRS).

Rögl, F., 1985. Late Oligocene and Miocene planktic foraminifera of the Central Paratethys. In Bolli, H. M., Saunders, J. B., and Perch-Nielsen, K. (Eds.), Plankton Stratigraphy: Cambridge (Cambridge Univ. Press): 315-328.

Savin, S. M., 1977. The history of the Earth's surface temperature during the past one hundred million years. Annu. Rev. Earth. Planet Sci., 5:319-344.

Sclater, J. G., and Mckenzie, D. P., 1973. Paleobathymetry of the South Atlantic. Geol. Soc. Am. Bull, 84:3203-3215.

Shutskaya, E. K., 1970. Stratigraphy, foraminifera and paleogeography of lower Paleogene of Crimea, Ciscaucasus, and western Central Asia. Vses. Nauchno-Issled. Geol.-Razved. Neft Inst. (VNIGNI), 70:1-256.
Sigal, J., 1974. Comments on Leg 25 sites in relation to the Cretaceous and Paleogene stratigraphy in the eastern and southeastern African and Madagascar regional setting. In Simpson, E.S.W., Schlich, R., et al., Init. Repts. DSDP, 25: Washington (U.S. Govt. Printing Office), 687-723.

Srinivasan, M. S., and Kennett, J. P., 1983. The Oligocene-Miocene boundary in the South Pacific. Geol. Soc. Am. Bull., 94:789-812.

Stainforth, R. M., Lamb, J. L., Luterbacher, H. P., Beard, J. H., and Jeffords, R. M., 1975. Cenozoic planktonic foraminiferal zonation and characteristics of index forms. Univ. Kans. Paleontol. Contrib. Art., 62:1-425

Stolk, J., 1965. Contribution à l'ètude des correlations microfaunique du Tertiaire inférieur de la Nigèrie méridionale. Mem. BRGM, $32: 247-267$

Subbotina, N. N., 1953. Fossil Foraminifera of the USSR: Globigerinidae, Hantkeninidae and Globorotalidae: London (Collet).

Tauxe, L., Tucker, P., Petersen, N. P., and LaBrecque, J. L., 1983. The magnetostratigraphy of Leg 73 sediments. Palaeogeogr., Palaeoclimatol., Palaeoecol., 42:65-90.

Tjalsma, R. C., 1977. Cenozoic Foraminifera from the South Atlantic, DSDP Leg 36. In Barker, P. F., Dalziel, I.W.D., et al., Init. Repts. DSDP, 36: Washington (U.S. Govt. Printing Office), 493-518.

Todd, R., and Kniker, H. T., 1952. An Eocene foraminiferal fauna from the Agua Fresca Shale of Magellanes Province, southernmost Chile. Spec. Publ. Cushman Found. Foraminiferal Res., 1:1-28.

Toumarkine, M., 1978. Planktonic foraminiferal biostratigraphy of the Paleogene of Sites 360 to 364 and the Neogene of Sites 362A, 363, and 364, Leg 40. In Bolli, H. M., Ryan, W.B.F., et al., Init. Repts. DSDP, 40: Washington (U.S. Govt. Printing Office), 679-738.

Toumarkine, M., and Bolli, H. M., 1975. Foraminifères planctoniques de l'Eocène moyen et supérieur de la coupe di Possagno (Italie). Schweiz. Paleontol. Abh, 97:69-185.

Toumarkine, M., and Luterbacher, H. P., 1985. Paleocene and Eocene planktic foraminifera. In Bolli, H. M., Saunders, J. B., and Perch-Nielsen, K. (Eds.), Plankton Stratigraphy: Cambridge (Cambridge Univ. Press), 87-154.

Ujiié, H., 1976. Prosphaeroidinella n. gen.: probable ancestral taxon of Sphaeroidinellopsis (Foraminifera). Bull. Nat. Sci. Mus., Ser. C: Geol. Paleontol. (Tokyo), 2:14-19.

van Andel, T. H., 1975. Mesozoic/Cenozoic calcite compensation depth and the global distribution of calcareous sediments. Earth Planet Sci. Lett., 26:187-195.

Weinzierl, L. L., and Applin, E. R., 1929. The Claibourne Formation on the coastal domes. J. Paleontol., 3:384-410.

Weissel, J. K., and Hayes, D. E., 1972. Magnetic anomalies in the southeast Indian Ocean. In Hayes, D. E. (Ed.), Antarctic Oceanology II: The Australian-New Zealand Sector. Antarct. Res. Ser., 19:165-196.

Date of initial receipt: 31 March 1989

Date of acceptance: 22 January 1990

Ms 114B-127 


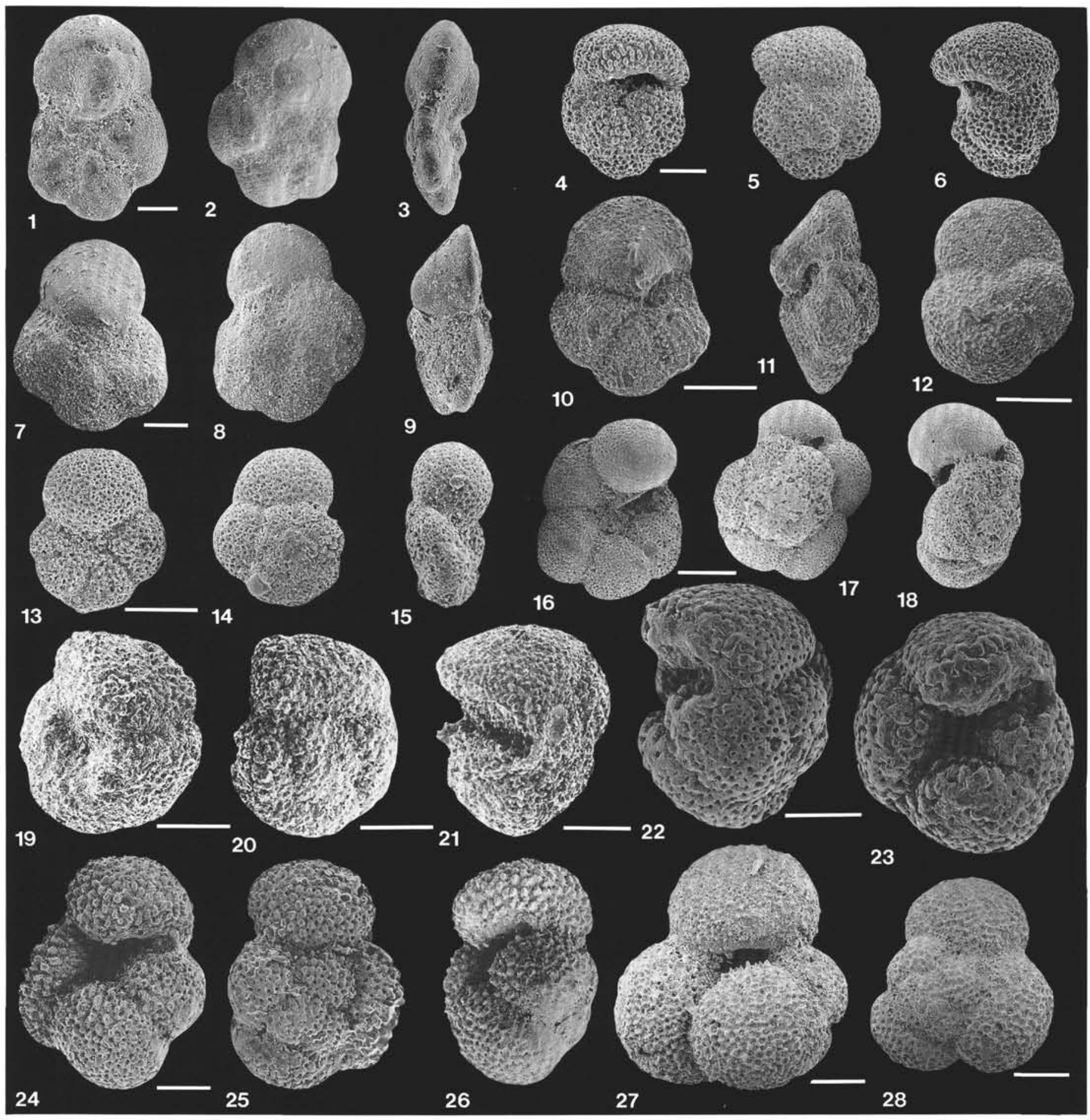

Plate 1. Late Paleocene and early Eocene planktonic foraminifers. Scale bar $=100 \mu \mathrm{m}$. Different views of a specimen have the same magnification. 1-3. Planorotalites ehrenbergi; Sample 114-700B-30R-3, 130-132 cm; late Paleocene (P4), (1) ventral view (v. v.), (2) dorsal view (d. v.), (3) side view (s. v.). 4-6. Acarinina nitida transition to A. primitiva; Sample 114-698A-9R-1, 94-96 cm; late Paleocene (P5-6a), (4) v. v., (5) d. v., (6) s. v. 7-9. Planorotalites pseudomenardii; Sample 114-698A-11R-CC; late Paleocene (P4), (7) v. v., (8) d. v., (9) s. v. 10-12. Planorotalites pseudoscitulus elongatus; Sample 114-698A-6R-CC; early Eocene (P8), (10) v. v., (11) s. v. Other specimen (12) d. v. 13-15. Globorotaloides sp.; Sample 114-698A-8R-CC; early Eocene (P6-7), (13) v. v., (14) d. v., (15) s. v. 16-18. "Globorotalia" aff. praecentralis; Sample 114-702B-23X-CC; early Eocene (P8), (16) v. v., (17) d. v., (18) s. v. 19-21. Acarinina nitida; Sample 114-699A-51X-CC; early Eocene (P8), (19) v. v. Other specimen (20) d. v. Other specimen (21) s. v. 22, 23. Acarinina acarinata; Sample 114-698A-6R-1, 110-112 cm; early Eocene (P8), (22) s. v., (23) v. v. 24-26. Acarinina esnaensis; Sample 114-698A-6R-CC; early Eocene (P8), (24) v. v., (25) d. v., (26) s. v. $27,28$. Subbotina ratusa; Sample 114-698A-4R-CC; early Eocene (P8), (27) v. v. Other specimen (28) d. v. 


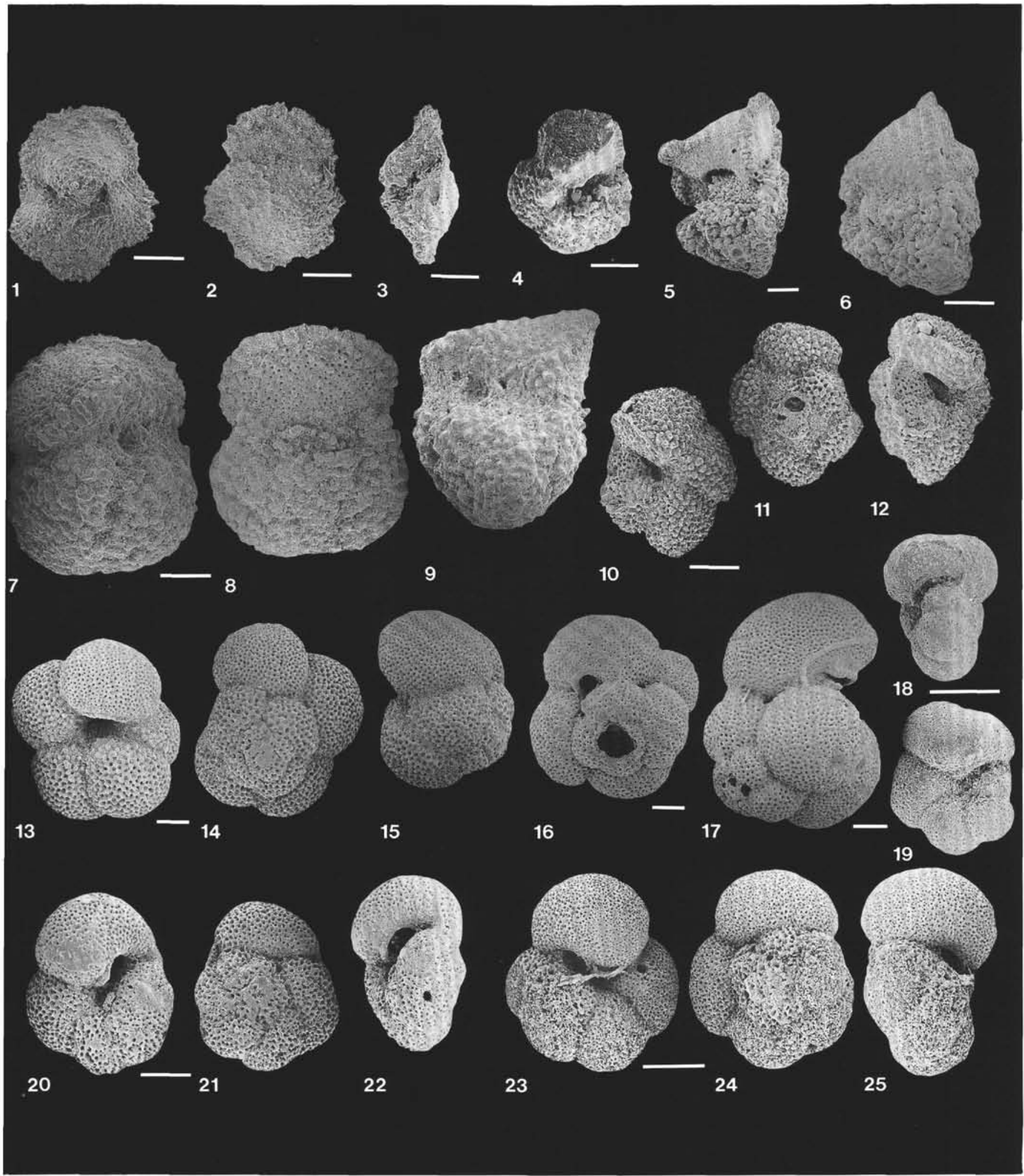

Plate 2. Early Eocene planktonic foraminifers. Scale bar $=100 \mu \mathrm{m}$. Different views of a specimen have the same magnification. 1-3. Morozovella marginodentata; Sample 114-700B-22R-CC; (P7), (1) ventral view (v. v.). Other specimen (2) dorsal view (d. v.). Other specimen (3) side view (s. v.). 4. Morozovella crater; Sample 114-699A-49X-4, 32-34 cm; (P9), v. v. 5. M. crater; Sample 114-702B-21X-CC; (P9), s. v. 6. Morozovella aragonensis; Sample 114-702B-21X-CC; (P9), s. v. 7-9. Morozovella dolabrata; Sample 114-698A-6R-CC; (P8), (7) v. v., (8) d. v., (9) s. v. 10-12. Acarinina aff. libyaensis; Sample 114-702B-20X-CC; (P9), (10) v. v., (11) d. v., (12) s. v. 13-16. Subbotina lozanoi; Sample 114-702B-21X-CC; (P9), (13) v. v., (14) d. v., (15) s. v. Other specimen with secondary sutural aperture (16) d. v. 17! Subbotina higginsi; Sample 114-702B-20X-CC; (P9), s. v. 18, 19. Pseudohastigerina sharkriverensis; Sample 114-698A-5R-CC; (P8), (18) umbilical-s. v., (19) peripheral view. 20-25. "Globorotalia" praecentralis; Sample 114-702B-23X-CC; (P8), (20) v. v., (21) d. v., (22) s. v. Other specimen (23) v. v., (24) d. v., (25) s. v. 


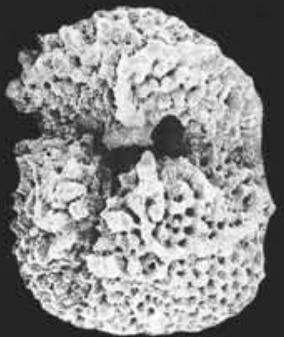

1

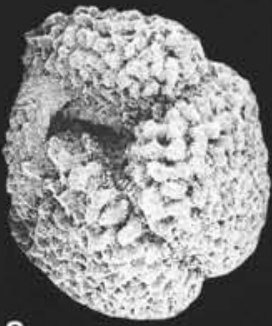

6

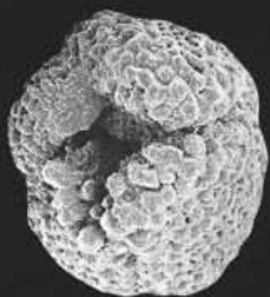

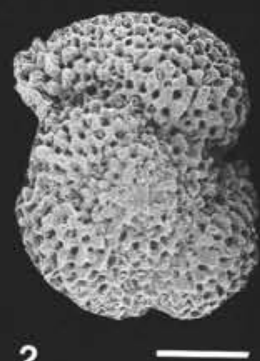

2

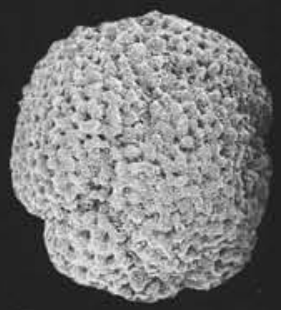

7

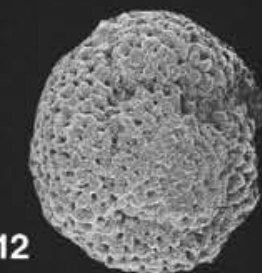

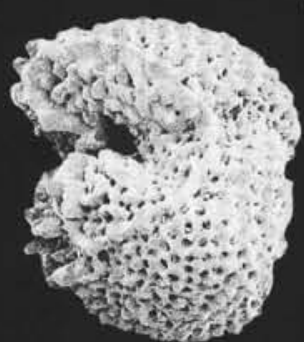

3

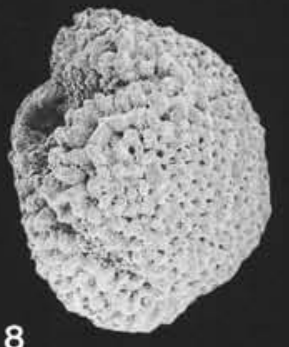

8

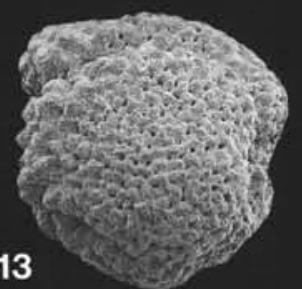

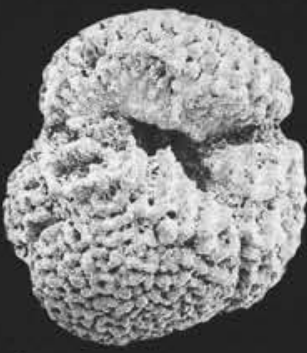

4

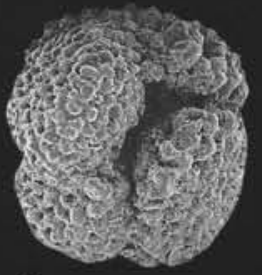

9

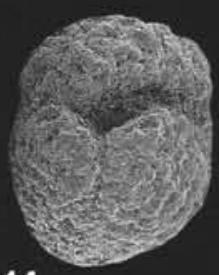

14

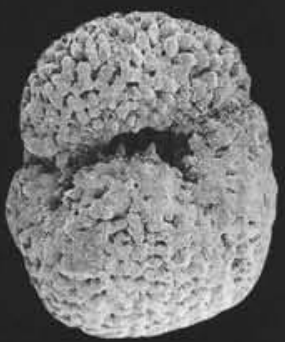

5

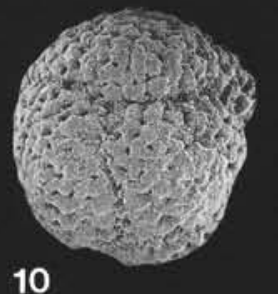

10
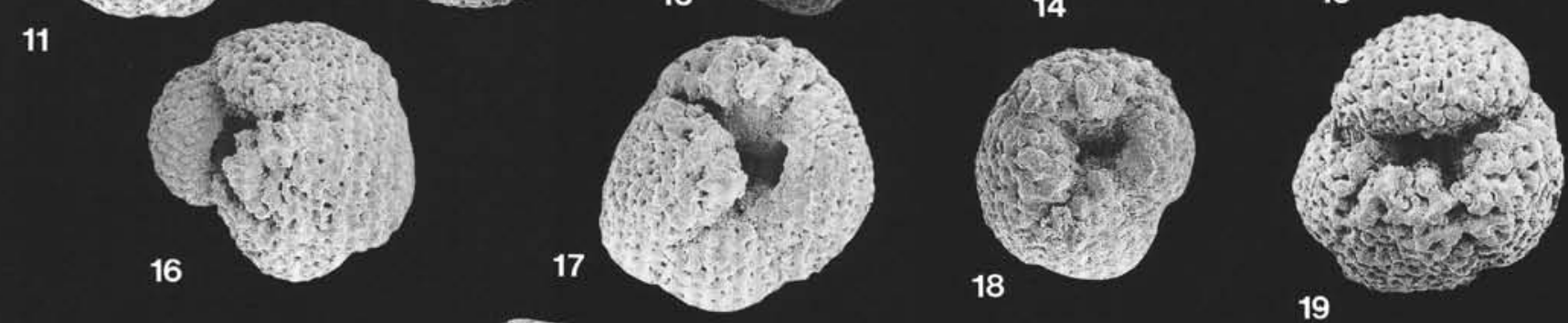

19
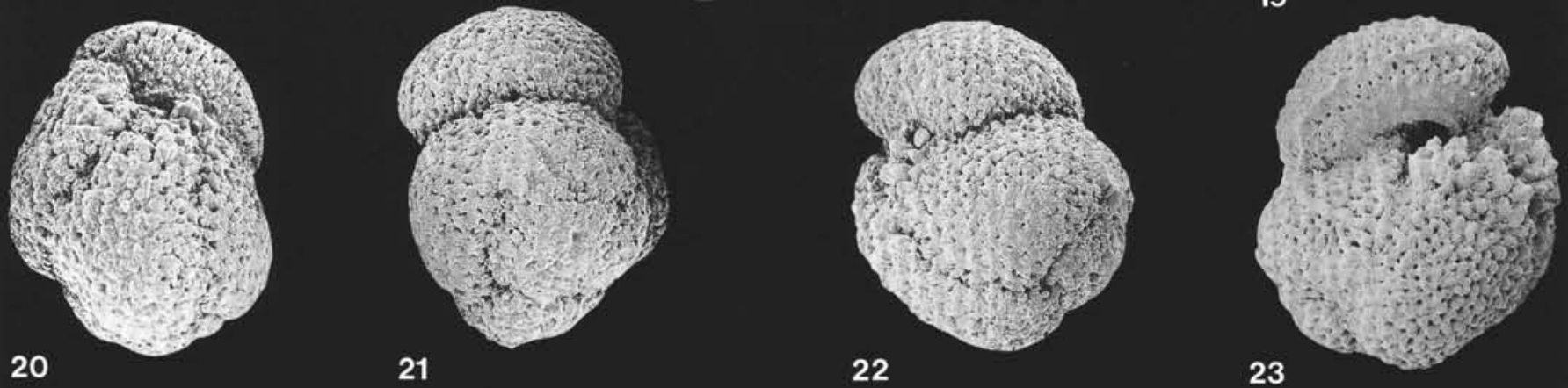

Plate 3. Acarinina primitiva variability; a. c. $=$ final abortive chamber. Scale bar $=100 \mu \mathrm{m}$. All the specimens have the same magnification. 1-4. Acarinina primitiva; Sample 114-698A-2R-CC; early Eocene (P9), (1) ventral view (v. v.), (2) dorsal view (d. v.), (3) side view (s. v.). Other specimen (4) v. v. 5. A primitiva; Sample 114-698A-1R-CC; early Eocene (P9), v. v. 6-8. A. primitiva with a. c.; Sample 114-698A-2R-CC; early Eocene (P9), (6) v. v., (7) d. v., (8) s. v. 9, 10. A. primitiva with a. c. (closed form); Sample 114-699A-43X-CC; early middle Eocene (P11), (9) v. v., (10) d. v. 11-13. A. primitiva with a. c. (closed form); Sample 114-698A-2R-CC; early Eocene (P9), (11) v. v., (12) d. v., (13) s. v. 14, 15. A. primitiva (closed form with umbilical-extraumbilical aperture); Sample 114-699A-43X-CC; early middle Eocene (P11), (14) v. v., (15) s. v. 16. A. primitiva with a. c.; Sample 114-698A-2R-CC; early Eocene (P9), s. v. 17, 18. A. primitiva with a. c. (very closed form); Sample 114-698A-1R-CC; early Eocene (P9), (17) v. v. Other specimen (18) v. v. 19. "Globigerinatheka" senni; Sample 114-698A-2R-CC; early Eocene (P9), v. v. 20-23. Acarinina aff, mattseensis alticonica; Sample 114-702B-21X-CC; early Eocene (P9), (20) oblique v. v., (21) d. v., (22) s. v. Other specimen (23) latero-ventral view. 


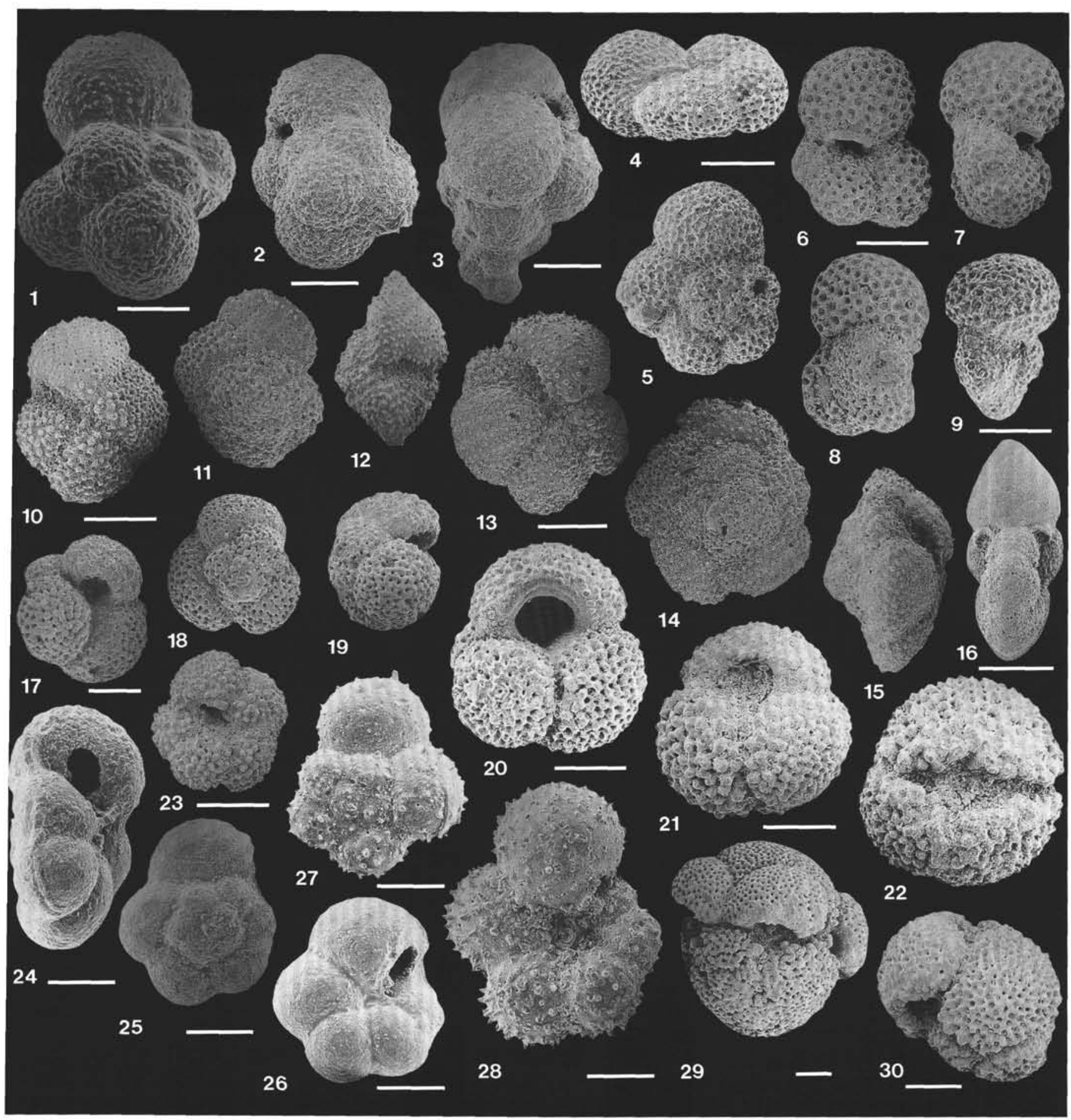

Plate 4. Middle Eocene-late Eocene planktonic foraminifers. Scale bar $=100 \mu \mathrm{m}$ unless otherwise indicated. Different views of a specimen have the same magnification. 1, 2. Cassigerinelloita amekiensis; Sample 114-703A-40X-CC; early middle Eocene (P10-11), (1) oblique (dorsal) view. Other specimen (2) side view (s. v.). 3. Guembelitria sp.; Sample 114-703A-40X-CC; early middle Eocene (P10-11), s. v. 4, 5. Globorotaloides aff. suteri; Sample 114-699A-45X-CC; early middle Eocene (P10-11), (4) latero-ventral view. Other specimen (5) dorsal view (d. v.). 6-8. Globorotaloides sp. 1; Sample 114-699A-43X-CC; early middle Eocene (P11), (6) ventral view (v. v.), (7) s. v., (8) d. v. 9. Globorotaloides sp. 1; Sample 114-699A-45X-CC; early middle Eocene (P10-11), s. v. 10-12. "Morozovella" nicoli; Sample 114-702B-13X-2, 140-142 cm; late middle Eocene (P11), (10) v. v., (11) d. v., (12) s. v. 13-15. "Morozovella" nicoli ? salisburgensis; Sample 114-703A-26X-CC; late middle Eocene (P11-12), (13) v. v., (14) d. v., (15) s. v. 16. Pseudohastigerina danvillensis; Sample 114-703A-26X-CC; late middle Eocene (P11-12), peripheral view. 17-19. Primitive Globigerinatheka index; Sample 114-702B-13X-3, 140-142 cm; late middle Eocene (P11), (17) v. v., (18) d. v., (19) s. v. 20-22. G. index; Sample 114-702B-12X-CC; late middle Eocene (P12), (20) v. v. Other specimen (21) v. v. Other specimen (22) v. v. 23. Acarinina medizzai; Sample 114-703A-17X-CC; late Eocene (P15), v. v. 24-26. "Praetenuitella" insolita; Sample 114-703A-15H-4, 25-27 cm; late Eocene (P16-17), (24) s. v. Other specimen (25) d. v. Other specimen (26) v. v. 27. "Acarinina" aculeata; Sample 114-703A-17X-CC; late Eocene (P15), d. v. 28. "A." aculeata; Sample 114-702A-4H-4, 130-132 cm; late Eocene (P15), v. v. 29. Globigerinatheka luterbacheri; Sample 114-702A-4H-3, 130-132 cm; late Eocene (P15). 30. Globigerinatheka rubriformis; Sample 114-702A-3H-CC; late Eocene (P15). 


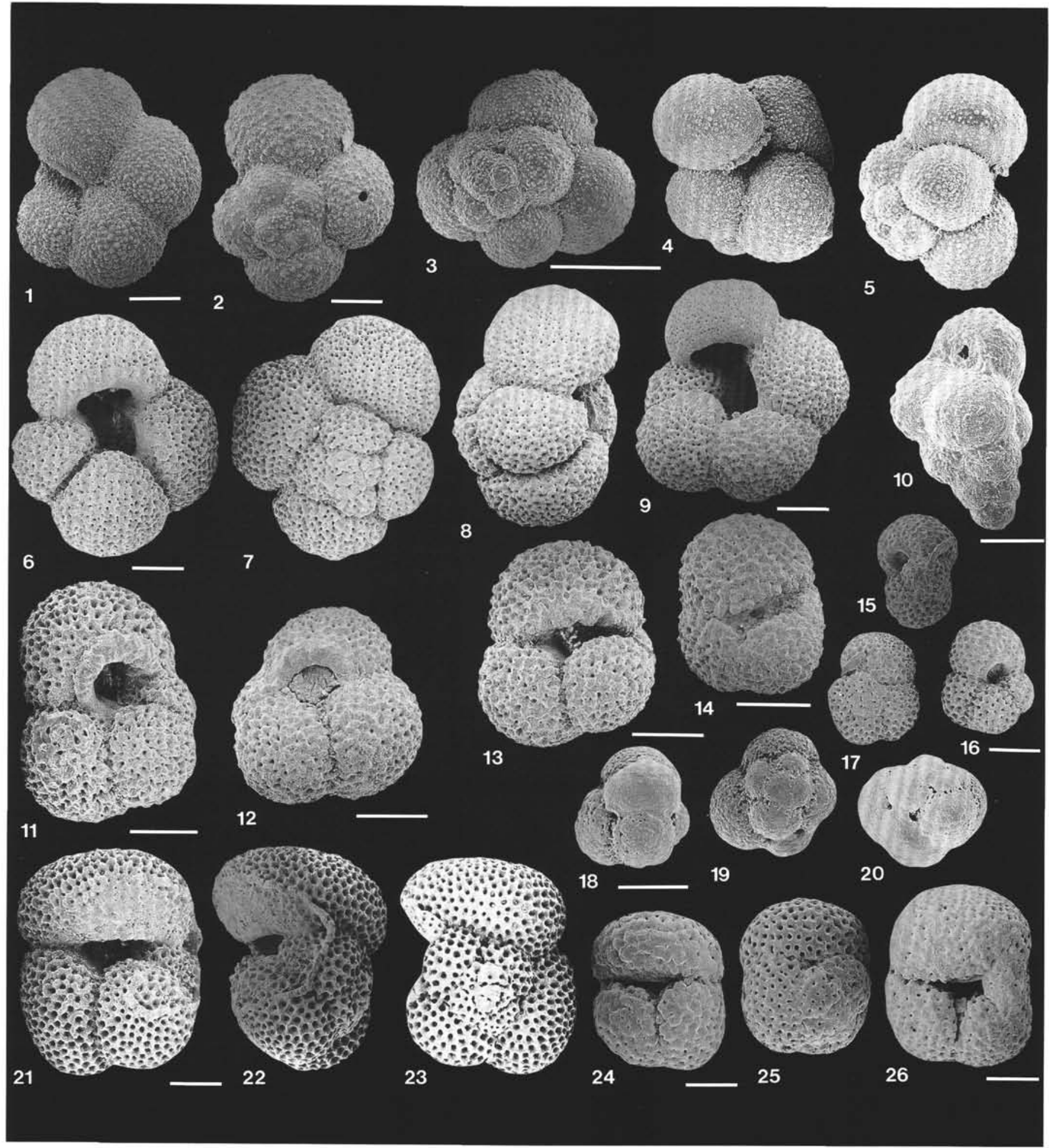

Plate 5. Oligocene-early Miocene planktonic foraminifers. Scale bar $=100 \mu \mathrm{m}$ unless otherwise indicated. Different views of a specimen have the same magnification. 1, 2. Tenuitella clemenciae; Sample 114-703A-10H-CC; early Oligocene, (1) ventral view (v. v.). Other specimen (2) dorsal view (d. v.). 3-5. Globigerinita juvenilis; Sample 114-703A-7H-CC; early Oligocene (P21a), (3) d. v., (4) v. v., (5) side view (s. v.). 6-8. "Globigerina" anguliofficinalis; Sample 114-703A-6H-CC; late Oligocene-early Miocene (P22-"N4"), (6) v. v., (7) d. v., (8) s. v. 9. "Globigerina" ciperoensis; Sample 114-703A-6H-CC; late Oligocene-early Miocene (P22-"N4"), v. v. 10. Guembelitria stavensis; Sample 114-703A-8H-6, 80-82 cm; early Oligocene (P21a). 11, 12. "Globigerina" labiacrassata; Sample 114-703A-9H-CC; early Oligocene, (11) v. v. Other specimen (12) v. v. 13, 14. ?Prosphaeroidinella sp.; Sample 114-703A-9H-CC; early Oligocene, (13) v. v. Other specimen (14) v. v. 15-17. “'Globigerina"' brazieri; Sample 114-703A-5H-4, 34-36 cm; early Miocene, (15) s. v., (16) v. v., (17) d. v. 18-20. Globigerinita incrusta; Sample 114-703A-7H-1, 124-126 cm; late Oligocene (P21b), (18) v. v., (19) d. v., (20) s. v. 21-23. Globoquadrina dehiscens; Sample 114-703A-4H-CC; early Miocene; (21) v. v., (22) s. v., (23) d. v. 24-26. Globoquadrina dehiscens praedehiscens; Sample 114-703A-6H-6, 115-117 cm; late Oligocene-early Miocene (P22-“N4"), (24) v. v., (25) d. v. Other specimen with bulla (26) v. v. 


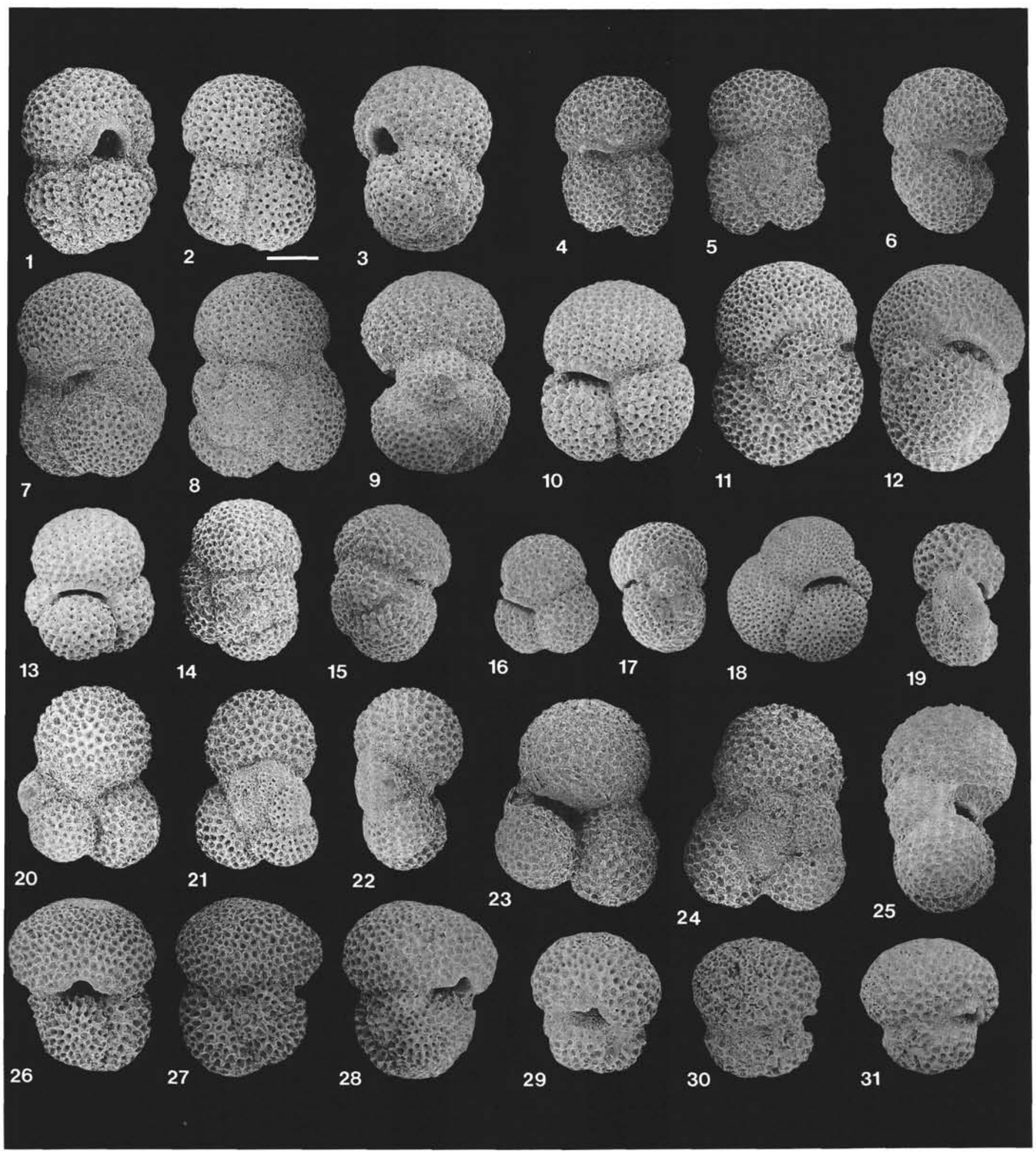

Plate 6. Trilobate subbotinids and globorotaloids. Scale bar $=100 \mu \mathrm{m}$. All the specimens have the same magnification. 1-3. Subbotina patagonica; Sample 114-700B-16R-6, 40-42 cm; early Eocene (P9); (1) ventral view (v. v.), (2) dorsal view (d. v.), (3) side view (s. v.). 4-6. Subbotina eocaenica; Sample 114-698A-3R-CC; early Eocene (P9), (4) v. v., (5) d. v., (6) s. v. 7-9. Subbotina eocaenica irregularis; Sample 114-698A-3R-CC; early Eocene (P9), (7) v. v., (8) d. v., (9) s. v. 10-12. Subbotina utilisindex; Sample 114-703A-12H-CC; early Oligocene, (10) v. v. Other specimen (11) d. v., (12) s. v. 13-15. Subbotina angiporoides minima; Sample 114-703A-12H-CC; early Oligocene, (13) v. v. Other specimen (14) d. v., (15) s. v. 16, 17. Subbotina utilisindex; Sample 114-703A-9H-CC; early Oligocene, (16) v. v. Other specimen (17) s. v. 18. Subbotina angiporoides; Sample 114-703A-19X-CC; late middle Eocene (P14), v. v. 19-22. Globorotaloides sp. 1; Sample 114-703A-12H-CC; early Oligocene, (19), dorsal-s. v. Other specimen (20) v. v., (21) d. v., (22) s. v. 23-25. Globorotaloides oregonensis; Sample 114-703A-12H-CC; early Oligocene, (23) v. v., (24) d. v., (25) s. v. 26-28. S. linaperta group; Sample 114-703A-19X-CC; late middle Eocene (P14), (26) v. v., (27) d. v., (28) s. v. 29-31. Subbotina linaperta group; Sample 114-702B-5X-CC; late Eocene (P15), (29) v. v., (30) d. v., (31) s. v. 